Report No. BMI-1459

UC-10 Chemistry - Separation Processes for Plutonium and Uranium (TID-4500, 15th Ed.)

Contract No. W-7405-eng-92

DEVELOPMENT OF CORROSION-RESISTANT ALLOYS FOR USE AS CONTAINER MATERIALS FOR DECLADDING SOLUTIONS OR AS WELDING ALLOYS

by

Charles L. Peterson

David C. Drennen

Merritt E. Langston

A. M. Hall

Walter K. Boyd

August 8, 1960

BATTELLE MEMORIAL INSTITUTE

$505 \mathrm{King}$ Avenue

Columbus 1, Ohio 


\section{DISCLAIMER}

This report was prepared as an account of work sponsored by an agency of the United States Government. Neither the United States Government nor any agency Thereof, nor any of their employees, makes any warranty, express or implied, or assumes any legal liability or responsibility for the accuracy, completeness, or usefulness of any information, apparatus, product, or process disclosed, or represents that its use would not infringe privately owned rights. Reference herein to any specific commercial product, process, or service by trade name, trademark, manufacturer, or otherwise does not necessarily constitute or imply its endorsement, recommendation, or favoring by the United States Government or any agency thereof. The views and opinions of authors expressed herein do not necessarily state or reflect those of the United States Government or any agency thereof. 


\section{DISCLAIMER}

Portions of this document may be illegible in electronic image products. Images are produced from the best available original document. 
ABSTRACT .............................. . . . . . . 1

INTRODUCTION . . . . . . . . . . . . . . . . . . . . . 1

THE FIRST SERIES OF 12 EXPERIMENTAL ALLOYS . . . . . . . . . . . . 2

Alloy Compositions . . . . . . . . . . . . . . . . 2

Melting Procedure . . . . . . . . . . . . . . . . . 2

Melting Stock. . . . . . . . . . . . . . . . 4

Charging . . . . . . . . . . . . . . . . . 4

Melting ........................... 5

Pouring ........................ 5

Recoveries ..................... 5

Radiographic Inspection ............... . . . 6

Fabrication. . . . . . . . . . . . . . . . . 6

Annealing . . . . . . . . . . . . . . . . . . . 7

Metallographic Examination . . . . . . . . . . . . . . 10

Allocation of the Annealed Strip . . . . . . . . . . . . . 12

Welding Procedure . . . . . . . . . . . . . . . . . 12

Corrosion Studies . . . . . . . . . . . . . . . . . . 13

Unwelded Specimens . . . . . . . . . . . . . . . . 13

Hastelloy $F$ Specimens With Weldments of Experimental Alloys • . 22

Self-Welded Specimens of the Experimental Alloys . . . . . . . . 30

Miscellaneous Corrosion Studies in Preparation for the Second

Alloy Scries. . . . . . . . . . . . . . . . . 33

Conclusions Based on the First Series of Experimental Alloys . . . . . 39

THE SECOND SERIES OF 12 EXPERIMENTAL ALLOYS . . . . . . . . . 41

Alloy Compositions . . . . . . . . . . . . . . . . . 41

Melting Procedure . . . . . . . . . . . . . . . . 42

Fabrication ...................... . . . . . 44

Forging . . . . . . . . . . . . . . . . . . . 44

Hot Rolling................... . . . . 44

Annealing . . . . . . . . . . . . . . . . . . . 44

Metallographic Examination . . . . . . . . . . . . . 46

Allocation of Strip and Description of Welding Procedure . . . . . . . 46

Corrosion Studies of Self-Welded Specimens. . . . . . . . . . . . 49

Sulfex Studies. . . . . . . . . . . . . . . . 49

Niflex Studies. . . . . . . . . . . . . . . . . . 49

CONCLUSIONS AND RECOMMENDATIONS BASED ON THE TWO SERIES

OF EXPERIMENTAL ALLOYS . . . . . . . . . . . . . . . 57

ACKNOWLEDGMENT . . . . . . . . . . . . . . . . . . . 62

REFERENCES. . . . . . . . . . . . . . . . . . . . 62 


\title{
DEVELOPMENT OF CORROSION-RESISTANT ALLOYS FOR. \\ USE AS CONTAINER MATERIALS FOR DECLADDING \\ SOLUTIONS OR AS WELDING ALLOYS
}

Charles I. Peterson, David C. Drennen, Merritt E. Langston, A. M. Hall, and Walter K. Boyd

\begin{abstract}
Twenty-four experimentul alloys were developed and evoluated as container materials or welding alloys for use with Sulfex and Niflex decladding solutions.
\end{abstract}

Niflex solutions, which were more corrosive than Sulfex solutions to most of the experimental alloys, produced severe localized attack at weldmems mode on vacum-melted Hastelloy fi with the experimental alloys. However, several of the alloys, when self-welded, were not selectively atiached. Some of these showed a substantial improvement in resistance to the declading solutions.

The most promising alloys were based on either $45 w / 0$ nickel-22 w/o chromium or $50 w / 0$ nickel-25 w/o chromiun, with at least $6 w / 0$ molybderum, and $1 w / 0$ ticanium, $0.6 w / 0$ manganese, $0.4 w / 0$ silicon, $0.02 w / 0$ carbon, and balance iron. The alloy mosi resistant to both solutions contained $6 w / 0$ molybdenum and 1 w/o copper in the 50 w/o nichel-25 w/o chromium base. Its corrosion rate of 22 mils per month in Niflex, with no selective allach, was significanlly lower than the $105 \mathrm{mils}$ per month recorded for Hastelloy $F$. Even lower rates would be expected under the less stringert conditions of actual process operation. Indications are that more resistance might be obtained by increasing the chromium and nichel contents.

\section{INTRODUCTION}

Technology for the reprocessing of certain spent power-reactor fuels is being developed currently at the Hanford Atomic Products Operation. The Sulfex process is contemplated for decladding stainless steel-clad fuels. The Niflex process, also being considered, incorporates the total dissolution of elements clad in either stainless steel or zirconium alloys. Both processes require the use of very corrosive solutions: in the first case, sulfuric acid, in the second, mixtures of nitric and hydrofluoric acids. Thereforc, the selection of a material of construction which might be used in a single dissolver vessel for either process has become of prime importance.

Extensive corrosion research, carried out at HAPO(1), indicated that vacuummelted Hastelloy $F$ was the most satisfactory single commercially available material of construction for use in a processing complex involving the Sulfex, Niflex, and Zirflex systems. The Zirflex process, also under consideration at HAPO, employs aqueous ammonium fluoride to dejacket zirconium-clad fuel elements.

(1) References at end. 
Unfortunately, the weldments of as-welded vacuum-rnelied Hastelloy $F$ were severely attacked preferentially by the Niflex solution under consideration (boiling 1.0 M $\mathrm{HNO}_{3}, 2.0 \mathrm{M} \mathrm{HF}$ ). In addition, accelerated attack also occurred in the heat-affected zones of weldments. A full solution anneal after welding apparently minimizes or eliminates this attack, but solution annealing of vessels of the geometry currently envisioned does not appear to be practical. Attempts have been made to solve this problem by finding a suitable weld metal for vacuum-melted Hastelloy $F$ which will resist the preferential attack of Niflex solutions without the requirement of a postwelding heat treatment.

Several candidate welding alloys were screened at HAPO. These included Haynes 25, Ni-o-nel, and modifications of the vacuum-melted Hastelloy $F$ composition. $(1,2)$ The resulting weldments exhibited varying degrees of resistance to Niflex solutions, but none appeared to be completely satisfactory.

In an effort to find a suitable welding material for use with vacuum-melted Hastelloy $F$ in Sulfex and Niflex solutions, an alloy-development program was initiated at Battelle Memorial Institute to supplement the studies at HAPO. In the beginning, 12 alloy compositions were proposed for study. These 12 alloys - essentially modifications of vacuum-melted Hastelloy $F$ in which one constituent was varied at a time - were designed for use both as welding materials for vacuum-melted Hastelloy $F$ and as materials of construction in their own right. When these alloys had been evaluated for corrosion resistance in Sulfex and Niflex solutions, it became evident that better results could be expected from the self-welded alloys than from welded vacuum-melted Hastelloy F. Consequently, the emphasis of the program was shifted at this point, and 12 additional alloys were produced and evaluated in the self welded condition only.

\section{THE FIRST SERIES OF 12 EXPERIMENTAI ALLOYS}

\section{Alloy Compositions}

The intended chemical compositions of the first series of 12 experimental alloys are given in Table 1. Analyzed compositions for three of the alloys are also listed in Table 1. Copper, molybdenum, niobium, and titanium contents were varied in a base alloy having a nominal composition of iron $-45 \mathrm{w} / 0$ nickel- $22 \mathrm{w} / 0 \mathrm{chromium}-0.6 \mathrm{w} / \mathrm{o}$ manganese $-0.4 \mathrm{w} / 0$ silicon $-0.02 \mathrm{w} / 0$ carbon. In addition, the densities of the 12 alloys, as determined by the water-displacement method, and which were used in calculating corrosion rates, are shown in the table.

\section{Melting Procedure}

To secure low impurity levels and a low carbon content the alloys were vacuum melted. The melting was done in an Alundum-lined induction furnace at a pressure of $1 \mu$ of mercury, or less. A 15-1b heat of each alloy was prepared. 
TABLE 1. COMPOSITIONS OF FIRST SERIES OF EXPERIMENTAL NICKEL-BASE CORROSION-RESISTANT WELDING ALLOYS

\begin{tabular}{|c|c|c|c|c|c|c|c|c|c|c|c|c|}
\hline \multicolumn{12}{|c|}{ Composition(a), w/o } & \multirow{2}{*}{$\begin{array}{l}\text { Density }(\mathrm{b}) \\
\text { g per } \mathrm{cm}^{3}\end{array}$} \\
\hline Alloy & C & $\mathrm{N}$ & $\mathrm{Ni}$ & $\mathrm{Cr}$ & Mo & $\mathrm{Cu}$ & $\mathrm{Nb}$ & $\mathrm{Ti}$ & $\mathrm{Mn}$ & Si & $\mathrm{Fe}$ & \\
\hline 1 & $\begin{array}{c}0.02 \\
(0.02)\end{array}$ & $(0.012)$ & 45.0 & 22.0 & 6.0 & 1.0 & 2.0 & -- & 0.6 & 0.4 & 23.0 & 8.25 \\
\hline 2 & $\begin{array}{c}0.02 \\
(0.01)\end{array}$ & $(0.010)$ & 45.0 & $\begin{array}{c}22.0 \\
(22.0)\end{array}$ & $\begin{array}{c}6.0 \\
(5.6)\end{array}$ & $\begin{array}{c}2.0 \\
(1.6)\end{array}$ & $\begin{array}{c}2.0 \\
(1.96)\end{array}$ & -- & $\begin{array}{c}0.6 \\
(0.7)\end{array}$ & $\begin{array}{c}0.4 \\
(0.44)\end{array}$ & 22.0 & 8.26 \\
\hline 4 & 0.02 & -- & 45.0 & 22.0 & 6.0 & $-\infty$ & $-\infty$ & 1.0 & 0.6 & 0.4 & 25.0 & 8.25 \\
\hline 5 & 0.02 & - & 45.0 & 22.0 & 3.0 & 2.0 & - & 0.5 & 0.6 & 0.4 & 26.5 & 8.22 \\
\hline 6 & $\begin{array}{c}0.02 \\
(0.01)\end{array}$ & $(0.011)$ & 45.0 & $\begin{array}{c}22.0 \\
(22.2)\end{array}$ & $\begin{array}{c}3.0 \\
(3.3)\end{array}$ & $\begin{array}{c}2.0 \\
(2.0)\end{array}$ & - & $\begin{array}{c}1.0 \\
(1.2)\end{array}$ & $\begin{array}{c}0.6 \\
(0.85)\end{array}$ & $\begin{array}{c}0.4 \\
(0.21)\end{array}$ & 26.0 & 8.22 \\
\hline 9 & 0.02 & - & 45.0 & 22.0 & 3.0 & 1.0 & 2.0 & $-\infty$ & 0.6 & 0.4 & 26.0 & 8.26 \\
\hline 10 & $\begin{array}{c}0.02 \\
(0.02)\end{array}$ & $(0.012)$ & 45.0 & 22.0 & 6.0 & 2.0 & -- & -. & 0.6 & 0.4 & 24.0 & 8.30 \\
\hline 11 & $\begin{array}{c}0.02 \\
(0.01)\end{array}$ & $=$ & 45.0 & $\begin{array}{c}22.0 \\
(22.2)\end{array}$ & $\begin{array}{c}6.0 \\
(6.4)\end{array}$ & $\begin{array}{c}2.0 \\
(1.8)\end{array}$ & - & $\begin{array}{c}1.0 \\
(1.2)\end{array}$ & $\begin{array}{c}0.6 \\
(0.76)\end{array}$ & $\begin{array}{c}0.4 \\
(0.19)\end{array}$ & 23.0 & 8.27 \\
\hline 12 & $\begin{array}{c}0.02 \\
(0.02)\end{array}$ & $(0.030)$ & 45.0 & 22.0 & 3.0 & 2.0 & 2.0 & -- & 0.6 & 0.4 & 25.0 & 8.24 \\
\hline
\end{tabular}


Melting Stock

The high-purity metals used as starting materials are shown in Table 2.

TABLE 2. METALS USED AS MELTING STOCK FOR THE FIRST SERIES OF EXPERIMENTAL ALLOYS

\begin{tabular}{ll}
\hline \multicolumn{1}{c}{ Metal } & Description \\
\hline Nickel & Electrolytic sheared stock \\
Chromium & Chromium metal $199.2 \mathrm{w} / 0 \mathrm{Cr}, 0.33 \mathrm{w} / \mathrm{F} \mathrm{F}$, \\
& $0.087 \mathrm{w} / 0 \mathrm{~N}, 0.03 \mathrm{w} / 0 \mathrm{C}, 0.20 \mathrm{w} / 0 \mathrm{Si}$, \\
& $0.027 \mathrm{w} / 0 \mathrm{Al}, 0.033 \mathrm{w} / 0 \mathrm{~S}, 0.006 \mathrm{w} / 0 \mathrm{P})$ \\
Molybdenum & Pure scrap \\
Copper & Electrolytic shot \\
Niobium & Ferrocolumbium $(59.2 \mathrm{w} / 0 \mathrm{Nb}, 6.88 \mathrm{w} / 0 \mathrm{Si}$, \\
& $0.31 \mathrm{w} / 0 \mathrm{C}, 2.33 \mathrm{w} / 0 \mathrm{Mn}, \sim 30 \mathrm{w} / 0 \mathrm{Fe})$ \\
Titanium & Unalloyed scrap \\
Manganese & Dehydrogenated electrolytic grade \\
Silicon & Silicon metal \\
Iron & Armco punchings $10.27 \mathrm{w} / 0 \mathrm{Cu}, 0.05 \mathrm{w} / 0 \mathrm{Mn}$, \\
& $0.03 \mathrm{w} / 0 \mathrm{Ni}, 0.017 \mathrm{w} / 0 \mathrm{C}, 0.015 \mathrm{w} / 0 \mathrm{Cr}$, \\
& $0.008 \mathrm{w} / 0 \mathrm{Mo}, 0.005 \mathrm{w} / 0 \mathrm{Si}, 0.004 \mathrm{w} / 0 \mathrm{Ti})$ \\
\hline
\end{tabular}

Charging

The following schedule is typical of the charging procedure used:

(1) A thin layer of nickel was placed on the bottom of the crucible.

(2) The next layer consisted of the molybdenum addition.

(3) Chromium and the remaining nickel were then placed on top of the molybdenum layer to reduce molybdenum losses from volatilization of its oxide.

(4) Armco iron was placed on top of the charge so that it would preheat above its Curie temperature and improve electrical inductance.

(5) Manganese, silicon, and ferrocolumbium were put in No. 1 charging cup while the titanium and copper additions were put in No. 2 charging cup. 
Melting

Typically, melting proceeded as follows:

(1) The crucible contents were melted by heating to about $2600 \mathrm{~F}$ as measured by an immersion thermocouple.

(2) The silicon, manganese, and ferrocolumbium were then added to the melt.

(3) Finally, titanium and copper were added to the melt just prior to pouring.

\section{Pouring}

During pouring the following procedure was employed:

(1) The temperature of the melt was held at $2600 \mathrm{~F}$.

(2) The melt was poured in vacuum into a zirconite sand mold to produce (a) a tapered rectangular ingot weighing about 8 to $9 \mathrm{lb}$, (b) a small pilot ingot of similar shape weighing about 1 to $1-1 / 2 \mathrm{lb}$, and (c) a tapered circular hot top weighing about 5 to $6 \mathrm{lb}$.

\section{Recoveries}

The results of the analyses, included in Table 1 , indicate that in some instances recoveries were somewhat different than predicted. The adjusted recovery factors shown in Table 3 were prepared for use in calculating the charges for additional vacuummelted experimental alloys of similar composition.

TABLE 3. RECOVERY FACTORS FOR EXPERIMENTAL NICKEL-BASE ALLOYS

\begin{tabular}{lcc}
\hline & \multicolumn{2}{c}{ Recovery Factor } \\
\cline { 2 - 3 } \multicolumn{1}{c}{ Addition Metal } & $\begin{array}{c}\text { Used in } \\
\text { First Series }\end{array}$ & Adjusted \\
\hline $\mathrm{Ni}, \mathrm{Fe}, 3 \mathrm{w} / 0 \mathrm{Mo}$ & 1.00 & 1.00 \\
$1 \mathrm{w} / 0 \mathrm{Ti}$ & 0.95 & 1.00 \\
$22 \mathrm{w} / 0 \mathrm{Cr}$ & 0.98 & 0.99 \\
$6 \mathrm{w} / 0 \mathrm{Mo}$ & 0.98 & 0.98 \\
$2 \mathrm{w} / 0 \mathrm{Nb}, 9 \mathrm{w} / 0 \mathrm{Mo}(\mathrm{a})$ & 0.95 & 0.95 \\
1 to $3 \mathrm{w} / 0 \mathrm{Cu}$ & 0.95 & 0.90 \\
$0.6 \mathrm{w} / 0 \mathrm{Mn}$ & 0.60 & 0.80 \\
$0.4 \mathrm{w} / 0 \mathrm{Si}$ & 0.90 & 0.70 \\
\hline \hline
\end{tabular}

(a) No supporting analytical data. 
Radiographic Inspection

Radiographic inspection revealed a shrinkage cavity or pipe extending from the hottop junction to a depth of from 1/4 to 1-1/2 in. into the ingot in each of the castings. These portions of the ingots were cropped. The pilot ingots were sound.

Fabrication

Forging. Preliminary studies were conducted on the small pilot ingots to determine a suitable forging temperature for each alloy. The pilot ingots were heated in a Globar furnace to $2150 \mathrm{~F}$. After soaking for about $30 \mathrm{~min}$, the ingots were forged to 1/2-in. -thick slabs. On the basis of the observed forging behavior and alloy composition, it was decided to lower the forging temperature to $2100 \mathrm{~F}$ for half of the alloys and to $2000 \mathrm{~F}$ for the remainder (see Table 4 ).

TABLE 4. FORGING BEHAVIOR OF FIRST SERIES OF EXPERIMENTAL ALLOYS

\begin{tabular}{ccll}
\hline \hline & $\begin{array}{c}\text { Forging } \\
\text { Temperature, } \\
\text { Flloy }\end{array}$ & $\begin{array}{c}\text { Relative } \\
\text { Eorgeability }\end{array}$ & \multicolumn{1}{c}{ Remarks } \\
\hline 1 & 2000 & Good & Several small cracks \\
2 & 2000 & Fair & Multiple edge, corner, and surface cracks \\
3 & 2100 & Very good & Few slight cracks \\
4 & 2100 & Very good & Few slight cracks \\
5 & 2100 & Very good & Few slight cracks \\
6 & 2100 & Very good & Few slight cracks \\
7 & 2000 & Fair & Multiple edge, corner, and surface cracks \\
8 & 2000 & Fair & Multiple edge, corner, and surface cracks \\
9 & 2000 & Fair & Multiple edge, corner, and surface cracks \\
10 & 2100 & Poor & Many deep edge and surface cracks \\
11 & 2100 & Very good & Few slight cracks \\
12 & 2000 & Good & Several small cracks \\
\hline
\end{tabular}

The ingots were then heated in a gas-fired furnace to the preselected forging temperature. After soaking for about $1 \mathrm{hr}$, the ingots were forged to about $3 / 4$-in. - thick slabs. The observed forging behavior of the 12 alloys is given in Table 4. In general, the titanium-containing alloys were superior in their forgeability to those alloys containing niobium additions. The poorest behavior was demonstrated by Alloy 10, which contained no titanium or niobium additions.

After forging, the slabs were reheated to 2000 or $2100 \mathrm{~F}$ and water quenched. Then the slabs were cut into two pieces of equal length and were pickled in an aqueous solution containing 45 parts of $\mathrm{HNO}_{3}$ and 10 parts of $\mathrm{HF}$, by volume. The removal of the oxide scale clearly revealed the presence of cracks in practically all of the alloys. Most of the cracks were removed by hot grinding prior to rolling; however, some of the deeper cracks could not be ground out. These cracks propagated during hot rolling. 
Hot Rolling. It was found that satisfactory $1 / 8$-in.-thicl strip for welding and corrosion evaluations could be obtained readily from the forged slabs of the pilot ingots by heating them to 2100 F and rolling with a 20 per cent reduction per pass with reheating after each pass. The forged slabs from the main ingots were processed in this manner except that the material was first cross rolled to a width of 5 to 7 in. After the last pass, the strip was allowed to cool in air prior to solution annealing.

The observed hot-rolling behavior of the 12 alloys is described in Table 5 . In general, the rolling behavior of an alloy was similar to its forging behavior. The alloys containing titanium were not nearly so prone to develop cracks as were those to which niobium had been added. As expected, Alloy 10 was the poorest of the series in this respect.

\section{TABLE 5. HOT-ROLLING BEHAVIOR OF THE FIRST SERIES OF EXPERIMENTAL ALLOYS}

\begin{tabular}{ccl}
\hline \hline Alloy & $\begin{array}{c}\text { Relative } \\
\text { Rollability }\end{array}$ & \multicolumn{1}{c}{ Remarks } \\
\hline 1 & Good & Very slight cracks \\
2 & Fair & Slight cracks, one deep crack \\
3 & Good & Very slight cracks \\
4 & Very good & No cracks \\
5 & Very good & No cracks \\
6 & Good & Very slight cracks \\
7 & Fair & Moderate to deep cracks \\
8 & Fair & Moderate to deep cracks \\
9 & Good & Very slight cracks \\
10 & Poor & Moderate to very decp cracks \\
11 & Very good & No cracks \\
\hline \hline
\end{tabular}

Annealing

Studies were made on specimens of hot-rolled strip to determine the optimum solution-annealing temperature for each of the 12 alloys. A treatment that would result in maximum solution of minor precipitated phases without causing excessive grain growth and oxidation was sought. On the basis of metallographic examinations of alloy structures and of an analysis of hardness data obtained from specimens annealed $30 \mathrm{~min}$ at temperatures ranging from 800 to $2200 \mathrm{~F}$ (see Table 6), three annealing temperatures were chosen: $1950 \mathrm{~F}$ for Alloys 5 and 6; $2050 \mathrm{~F}$ for Alloys 3, 4, 9, 10, 11, and 12; and 2150 F for Alloys 1, 2, 7, and 8.

A plot of hardness versus annealing temperature produced the four distinct bands of curves shown in Figure 1. Hardness data for Alloys 5 and 6, which were modified Nio-nel compositions, fell into the lowest band, while the highest band included data from only Alloy 8 , the $9 \mathrm{w} / 0$ molybdenum composition. Just below the curve for Alloy 8 was 
TABLE 6. EFFECT OF ANNEALING TEMPERATURE ON HARDNESS OF FIRST SERIES OF HOT-ROLLED EXPERIMENTAL ALLOYS

\begin{tabular}{|c|c|c|c|c|c|c|c|c|c|c|c|}
\hline \multirow[b]{3}{*}{ Alloy } & \multicolumn{10}{|c|}{ Rockwell A Hardness } & \multirow{3}{*}{$\begin{array}{c}\text { Optimum Annealing } \\
\text { Temperature, } F\end{array}$} \\
\hline & \multirow{2}{*}{$\begin{array}{l}\text { As Hot } \\
\text { Rolled }\end{array}$} & \multicolumn{9}{|c|}{ After Annealing $30 \mathrm{Min}$ At Indicated Temperature } & \\
\hline & & $800 \mathrm{~F}$ & $1200 \mathrm{E}$ & $1600 \mathrm{~F}$ & $1700 \mathrm{E}$ & $1800 \mathrm{E}$ & $1900 \mathrm{~F}$ & $2000 \mathrm{E}$ & $2100 \mathrm{~F}$ & $2200 \mathrm{E}$ & \\
\hline 1 & 63 & $-\infty$ & $-\infty$ & -- & 60.5 & 57 & 54.5 & 50 & 49.5 & 48 & 2150 \\
\hline 2 & 63.5 & 63 & 64 & 61 & 59.5 & 56.5 & 54.5 & 51 & 50 & 48 & 2150 \\
\hline 3 & 59 & 61 & 60 & 53.5 & 53.5 & 48.5 & 49.5 & 48 & 46.5 & 44.5 & 2050 \\
\hline 4 & 60 & -- & -- & -- & 56.5 & 50 & 49.5 & 49 & 46.5 & 45 & 2050 \\
\hline 5 & 58.5 & 58 & 57 & 46.5 & 47 & 45.5 & 46 & 44 & 43.5 & 41 & 1950 \\
\hline 6 & 58.5 & 57.5 & 56.5 & 50 & 46.5 & 46 & 47 & 45 & 44 & 41.5 & 1950 \\
\hline 7 & 64 & -- & -- & -- & 60 & 57 & 57 & 50.5 & 49.5 & 47 & 2150 \\
\hline 8 & 67.5 & 66.5 & 67 & 62.5 & 62.5 & 61 & 60 & 54.5 & 52.5 & 50.5 & 2150 \\
\hline 9 & 60 & -- & -- & $-\infty$ & 54.5 & 50 & 50.5 & 49.5 & 47.5 & 45 & 2050 \\
\hline 10 & 62.5 & -- & -- & -- & 51 & 49.5 & 49 & 47 & 46 & 45 & 2050 \\
\hline 11 & 57.5 & $\ldots$ & $-\infty$ & - & 56 & 49.5 & 49.5 & 48 & 46 & 44.5 & 2050 \\
\hline 12 & 59.5 & 61 & 61.5 & 53 & 51 & 50.5 & 49.5 & 47.5 & 46.5 & 44.5 & 2050 \\
\hline
\end{tabular}




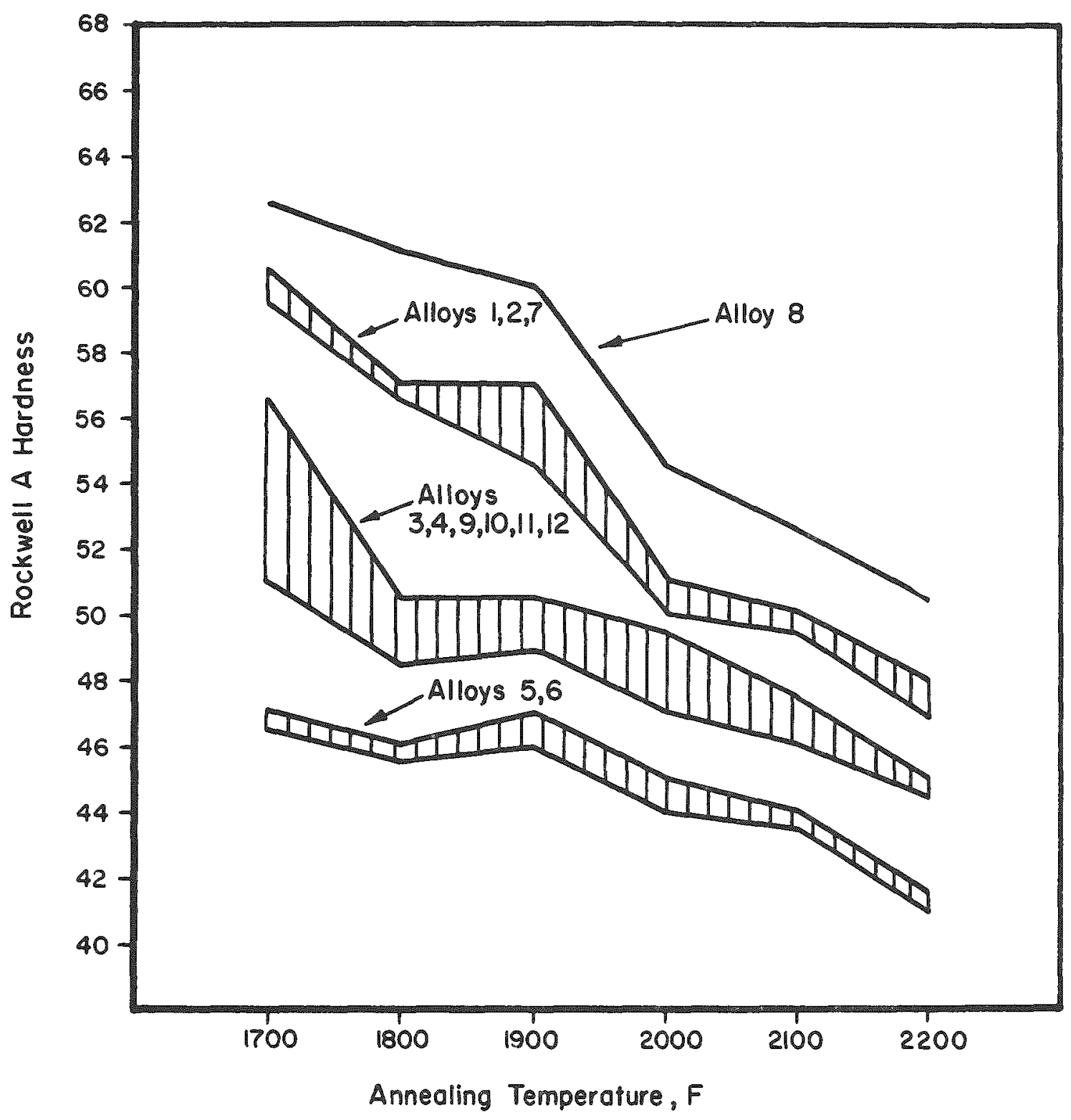

FIGURE 1. EFFECT OF ANNEALING TEMPERATURE ON THE HARDNESS OF THE EXPERIMENT AL ALLOYS OF THE FIRST SERIES 
a band containing the data for Alloys 1, 2, and 7, all of which contained $6 \mathrm{w} / 0$ molybdenum plus $2 \mathrm{w} / 0$ niobium plus 1,2 , or 3 w/o copper. Data from the remaining alloys fell into the band second from the lowest.

The bulk of the hot-rolled 1/8-in.-thick strip material destined for welding and corrosion evaluations was subsequently annealed for a period of $1 \mathrm{hr}$ at the appropriate temperature and then water quenched. Rockwell $B$ hardness values for this material are given in Table 7. In general, the hardness curves fell within the bands previously established for the different alloys during preliminary annealing studies. Although a direct comparison of hardness and composition is somewhat complicated by the fact that three solution-annealing temperatures were used, a few general observations are possible. For example, a higher hardness was observed when the molybdenum content increased from 3 to 6 and from 6 to $9 \mathrm{w} / 0$; whereas, variations in copper content had no significant effect on hardness.

\section{TABLE 7. ROCKWELL B HARDNESS OF SOLUTION-ANNEALED STRIP OF THE FIRST SERIES OF EXPERIMENTAL ALLOYS}

\begin{tabular}{ccc}
\hline & $\begin{array}{c}\text { Solution-Annealing } \\
\text { Temperature, } \\
\text { Alloy }\end{array}$ & $\begin{array}{c}\text { Rockwell B } \\
\text { Hardness }\end{array}$ \\
\hline 1 & 2150 & 81.5 \\
2 & 2150 & 81.5 \\
3 & 2050 & 80.0 \\
4 & 2050 & 78.5 \\
5 & 1950 & 76.0 \\
6 & 1950 & 74.0 \\
7 & 2150 & 82.0 \\
8 & 2150 & 87.0 \\
9 & 2050 & 84.0 \\
10 & 2050 & 78.0 \\
11 & 2050 & 77.0 \\
12 & 2050 & 77.5 \\
\hline
\end{tabular}

Metallographic Examination

Metallographic examination of the solution-annealed strip revealed a generally fine-grained austenitic matrix containing randomly dispersed minor phases, presumed to be complex carbides, nitrides, and an intermetallic compound. The amount of undissolved phases was considerably less in the titanium-bearing alloys than in those containing niobium. The quantity of the intermetallic compound appeared to increase with higher molybdenum contents, whereas variations in the copper content from 1 to 3 w/o had no noticeable effect on microstructure. The microstructure of 2 of the 12 experimental alloys and of vacuum-melted Hastelloy $F$, Heat FV 123, are shown in Figure 2. Alloy 11 is representative of those compositions (Alloys 3, 4, 5, 6, 9, 10, 11 , and 12) 

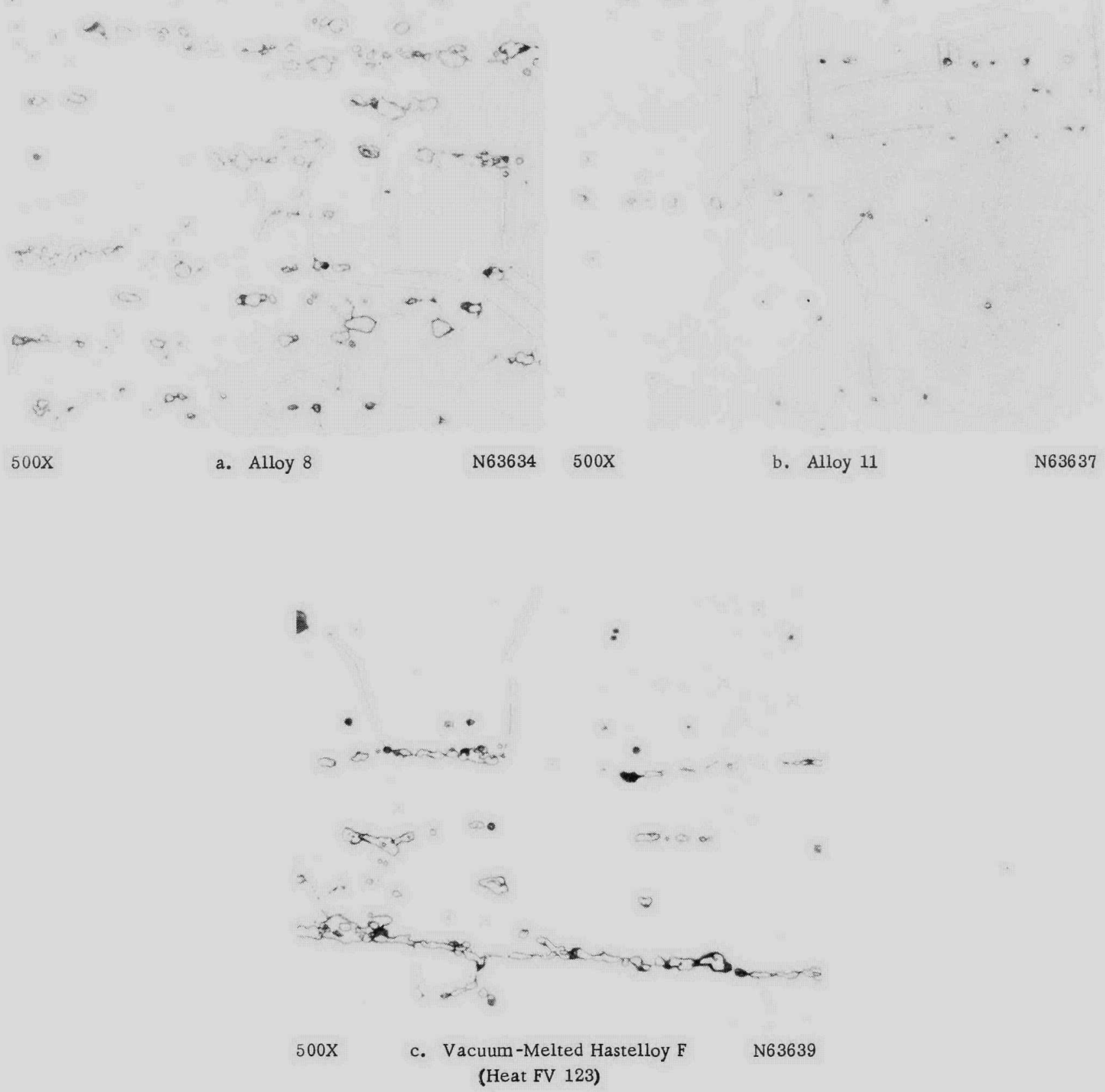

FIGURE 2. MICROSTRUCT URES OF TWO SOLUTION-ANNEALED EXPERIMENTAL NICKEL-BASE ALLOYS OF THE FIRST SERIES AND OF HASTELLOY F

The microstructure of Alloy 8 is representative of those of Alloys 1,2, and 7; that of Alloy 11 is representative of the remaining alloys. 
containing a very slight amount of minor phases; while Alloy 8 is typical of the remaining alloys, which contained a moderate amount of undissolved phases. The Hastelloy $F$ contained slightly more second phase than Alloy 11.

The specimens were prepared for metallographic examination according to the following procedure:

(1) Sawed on a cutoff wheel parallel with the rolling direction

(2) Ground successively on 240-, 400-, and 600-grit paper

(3) Polished on Blue Diamond wheel for about 200 laps

(4) Polished on Microcloth for about 50 laps

(5) Etched by swabbing with a 3:1 solution of concentrated $\mathrm{HCl}$ and $\mathrm{HNO}_{3}$ for 15 to 20 sec.

\section{Allocation of the Annealed Strip}

The finished rolled and annealed strip material from the first sexies of experimental alloys was of various sizes and shapes, depending on the amount that had to be ground from the forged slabs to eliminate cracks. There were two pieces of each alloy each roughly rectangular and averaging about 5 by 9 in. in dimensions. A rectangular area 3 by 9 in., or an equivalent area, was cut from one strip of each alloy and sent to HAPO for evaluation at that site. From the other strip of each alloy, a rectangular piece, 1-3/4 by 5 in., was cut for subsequent machining into eight coupon-type corrosion specimens. Also, two rectangular pieces, $1-1 / 4$ by 7 in., were cut adjacent to each other from this second strip for the fabrication of welded corrosion specimens. All of these pieces were sawed from the strips using a band saw. The location of each piece and the subsequent location of specimens cut from that piece were mapped in the event that corrosion data might indicate a compositional or structural anomaly in a certain area of a strip.

\section{Welding Procedure}

The two 1-1/4 by 7-in. pieces from each alloy, and similar pieces of vacuummelted Hastelloy $F$, Heat FV 123, were butt welded together in the same relationship that they were sawed from the strip.

Welding was done by the argon-shielded tungsten-arc method. The tungsten electrode (1/16 in. in diameter, $1 \mathrm{w} / 0$ thoriated tungsten) was on straight polarity (electrode negative) using a d-c source of 20 to $22 \mathrm{v}$ at 40 to $45 \mathrm{amp}$. The filler metal for the weldments was square rod about $1 / 8$ in. thick sheared from either Hastelloy $F$ or the experimental alloys and pickled prior to use.

The strips of base metal were beveled to give a single V-joint with a 75-deg included angle between the butted edges. They, like the filler rods, were pickled in an 
aqueous solution comprising 45 per cent concentrated HNO 3 and 0 , 5 ment nncentrated HF, by volume. The pieces were then clamped in a copper jig, Ieaving a root gap of about $1 / 16$ in. This jig was equipped with an outlet for argon below the weld. An argon flow of $12 \mathrm{ft}^{3}$ per hr was used for this backup. A similar flow race was used around the shielded tungsten electrode. The two beveled pieces were tack welded at one end, and a copper block was laid in the bevel. This forced the flow of the backup gas to be distributed along the gap. Welding was started at the opposite end using a manual fore-hand technique. A single pass at about 1.5 in. per min was used. The copper block was slid along the bevel as welding proceeded so that all but the area already welded was covered. The filler strip was fed by hand. Approximately 20 to $30 \mathrm{~g}$ of filler material was used for each weld (about $6-1 / 2$ in. in length).

During welding, the shielding was not so effective as intended, and it was feared that the weldments might have been contaminated with nitrogen. These weldments were sheared out, the remaining pieces were beveled, pickled, and rewelded with more efficient shielding. It was thought that this reworking of the strip was done in such a manner that no contamination was carried over from the first welding.

All of the welds were radiographed, and areas showing incomplete penetration were marked and avoided during the fabrication of corrosion specimens.

Corrosion Studies

Unwelded Specimens

Coupons, $1-1 / 2$ by $1 / 2$ by $1 / 8$ in., were sawed, machined, and surface ground from strip stock representing each of the 12 experimental alloys and the vacuum-melted Hastelloy F Heat FV 123. A 3/16-in. hole was centered at one end of each coupon, and the coupons were suspended by these holes during testing. As mentioned before, the coupons were identified so that their positions in the original strips could be located in the event that anomalous corrosion behavior occurred.

Sulfex Studies. The Sulfex corrosion studies were carried out in glassware consisting of 1-liter Erlenmeyer flasks with a standard-taper top for insertion of specimens and a standard-taper side arm topped by a water-cooled Allihn condenser. Teflon sleeves were used in place of grease on all ground-glass joints. The top of the condenser was capped by a small inverted beaker to discourage down drafts and free flow of air currents. Four specimens were suspended in each flask from a glass hanger, two completely immersed and two in the vapor phase above the boiling liquid. Six hundred milliliters of a stock acid solution ( $\left.3.5 \mathrm{M} \mathrm{H}_{2} \mathrm{SO}_{4}\right)$ was placed in each flask at the beginning of each 24-hr-exposure period. This is roughly $210 \mathrm{ml}$ of solution per in. 2 of submerged specimen area. The boiling point of such a solution is 107.5 C. When the acid had reached boiling, $12 \mathrm{~g}$ of small chips sheared from clean, Type 304 ELC stainless steel sheet about 40 mils thick was added to the acid. This is equivalent to $20 \mathrm{~g}$ per liter, and reaction gives a solution about $3.14 \mathrm{M}$ with respect to $\mathrm{H}_{2} \mathrm{SO}_{4}$. Dissolution of this stecl, which took around $2 \mathrm{hr}$ for completion, was allowed before the specimens were introduced for 24-hr-exposure periods to the refluxing acid. Following exposure, the specimens were removed, thoroughly rinsed in tap water while being scrubbed with a bristle brush, rinsed with distilled water and acetone, and oven dried. Then weight losses 
weie determined. The specimens were rotated to different llasks on subsequent exposure periods to average out any peculiarities in a particular flask-condenser system.

The corrosion rates were calculated for each $24-h x$ pexiod in terms of penetration in mils per month. The rates for this set of unwelded coupons are given in Table 8 . The averaged rates for the duplicate submerged specimens are shown graphically in Figure 3 , and the appearance of representative submerged specimens following the five 24-hr exposure periods is shown in Figure 4.

The attack was reasonably uniform on all of the specimens. There is no real basis from these results for selecting one alloy over another. The outstanding feature is that a state of borderline passivity existed for the alloys in this medium. During every exposure period some alloys were active; during others they were passive. Several more exposure periods would be required to average this effect and ascertain which alloys were superior. It will be observed that the corrosion rates for vapor-phase specimens were never as high as those for submerged specimens in the active condition. This is reasonable since the vapor in this case should be almost pure water except for acid carried up by splashing and entrainment.

Niflex Studies. The Niflex studies were conducted in equipment constructed from Kel-F and Teflon. Eight-ounce $\mathrm{Kel}-\mathrm{F}$ bottles were fitted with Teflon adapters which screwed onto the threaded necks of the bottles and which extended to sleeves at the upper ends. Lengths of thin-walled Teflon tubing were pressure fitted onto these sleeves and enclosed by glass water jackets to form condensers. The bottles were immersed in baths of $\mathrm{CaCl}_{2}$ brine held in beakexs covered with watch glasses. These baths, heated nearly to boiling, provided sufficient heat for refluxing the solutions. Free access of air to the top of the condensers was blocked by inverted plastic bottles. Neither solution nor vapor came in contact with any glassware. A quantity of $145 \mathrm{ml}$ of stock acid $11 \mathrm{M}$ $\mathrm{HNO}_{3}, 2 \mathrm{MHF}$ ) was used in each Kel- 5 bottle. The mouths of the bottles were too narrow to permit insertion of duplicate specimens at the submerged and vapor-phase positions on the Teflon rod holder, so only one specimen in each position could be exposed at a time. This is a ratio of about $75 \mathrm{ml}$ solution per in. 2 of submerged specimen area. Fresh solutions were used for each $24-h r$ exposure period. The specimens were rotated from bottle to bottle during the exposure periods and were washed, brushed, rinsed, and dried prior to weighing in the same manner as those exposed to the Sulfex solution.

The corrosion rates of the unwelded specimens are tabulated in Table 9. The graphical representation of the rates and the appearance of representative submerged specimens following exposure are shown in Figures 5 and 6 , respectively.

The materials were attacked much more severely by the Niflex solution than by the Sulfex solution and were active during each exposure period. The penetration in mils is plotted versus the duration of exposure in Figure 7. Several interesting observations can be made from this figure. The corrosion rates of all of the experimental alloys were nearly uniform, resulting in the penetration being practically a linear function of time. Two alloys, 7 and 8, appear to have had short induction periods but then corroded uniformly. The corrosion rate of the vacuum-melted Hastelloy $F$, however, kept increasing with continued exposure. Figure 7 also shows that Alloys 3 and 10 were the most resistant, closely followed by Alloys 4 and 11. Such a pattern reappears in the subsequent studies of welded specimens. 
TABLE 8. CORROSION RATES OF UNWELDED SPECIMENS OF THE FIRST SERIES UPON EXPOSURE TO BOILING SULFEX SOLUTIONS(a)

\begin{tabular}{|c|c|c|c|c|c|c|c|c|c|c|c|c|}
\hline \multirow{4}{*}{$\frac{\text { Alloy }}{\text { Hastelloy }}$} & \multirow{3}{*}{$\begin{array}{c}\begin{array}{c}\text { Specimen } \\
\text { Position }\end{array} \\
\text { Vapor }\end{array}$} & \multicolumn{11}{|c|}{ Corrosion Rate Each 24-Hir Period, mils per month } \\
\hline & & \multicolumn{2}{|c|}{ First } & \multicolumn{2}{|c|}{ Second } & \multicolumn{2}{|c|}{ Third } & \multicolumn{2}{|c|}{ Fourth } & \multicolumn{2}{|c|}{ Filfu } & \multirow[t]{3}{*}{ Liquid Average } \\
\hline & & 0.7 & 0.6 & 0.3 & 0.5 & 0.3 & 0.3 & 0.6 & 0.1 & 0.1 & 0.1 & \\
\hline & Liquid & 2.3 & 2.4 & $g^{(b)}$ & 0.3 & 3.9 & 3.4 & $g$ & 0.3 & 6.2 & 5.3 & \\
\hline \multirow[t]{2}{*}{1} & Vapor & 0.3 & 0.3 & 0.4 & 0.3 & 0.1 & 0.1 & 0.1 & 0.3 & 0.4 & 0.5 & \\
\hline & Liquid & 3.3 & 3.2 & 0.3 & 0.3 & 7.9 & 7.3 & 0.2 & 0.2 & 0.4 & 0.4 & 2.35 \\
\hline \multirow[t]{2}{*}{2} & Vapor & 0.3 & 0.2 & 0.2 & 0.2 & 0.2 & 0.2 & 0.2 & 0.2 & 0.3 & 0.3 & \\
\hline & Liquid & 2.4 & 2.4 & 0.3 & 0.3 & 0.2 & 0.2 & 4.7 & 5.2 & 0.3 & 0.3 & 1.63 \\
\hline \multirow[t]{2}{*}{3} & Vapor & 0.6 & 0.6 & 0.3 & 0.2 & 0.1 & 0.4 & 0.4 & 0.3 & 0.5 & 0.5 & \\
\hline & Liquid & 2.0 & 1.9 & 6.9 & 12.2 & 8.8 & 3.1 & 3.9 & 3.4 & 0.3 & 0.2 & 4.27 \\
\hline \multirow[t]{2}{*}{4} & Vapor & 0.7 & 0.6 & 0.8 & 0.3 & 0.5 & 0.4 & 0.1 & 0.2 & 0.5 & 0.6 & \\
\hline & Liquid & 2.4 & 2.3 & 0.3 & 0.3 & 0.2 & 0.2 & 3.0 & 3.1 & 0.3 & 0.2 & 1.23 \\
\hline \multirow[t]{2}{*}{5} & Vapor & 0.5 & 0.5 & 0.1 & 0.3 & 0.3 & 0.2 & 0.4 & 0.1 & 0.3 & 0.3 & \\
\hline & Liquid & 2. 2 & 2.3 & 0.4 & 0.5 & 4.4 & 3.0 & 0.2 & 0.2 & 0.2 & 0.2 & 1.36 \\
\hline \multirow[t]{2}{*}{6} & Vapor & 0.5 & 0.4 & 0.2 & 0.3 & 0.4 & 0.4 & 0.4 & 0.3 & 0.3 & 0.8 & \\
\hline & Liquid & 2.7 & 2.6 & 5.6 & 5.1 & 0.3 & 0.2 & 4.3 & 4.4 & 0.2 & 0.2 & 2.56 \\
\hline \multirow[t]{2}{*}{7} & Vapor & 0.4 & 0.4 & 0.4 & 0.3 & 0.3 & 0.3 & 0.4 & 0.4 & 0.1 & 0.1 & \\
\hline & Liquid & 4.2 & 4.5 & 2.3 & 2.3 & 0.3 & 0.4 & 0.2 & 0.1 & 0.3 & 0.3 & 1.49 \\
\hline \multirow[t]{2}{*}{8} & Vapor & 0.5 & 0.4 & 0.3 & 0.2 & 0.3 & 0.3 & 0.2 & 0.2 & 0.1 & 0.2 & \\
\hline & Liquild & 5.6 & 5.4 & 0.4 & 0.4 & 0.4 & 0.5 & 0.2 & 0.2 & 3.2 & 3.1 & 1.34 \\
\hline \multirow[t]{2}{*}{9} & Vapor & 0.3 & 0.3 & 0.3 & 0.5 & 0.6 & 0.4 & 0.5 & 0.4 & 0.1 & 0.2 & \\
\hline & Liquild & 2.7 & 2.7 & 0.3 & 0.2 & 0.4 & 0.5 & 0.2 & 0.2 & 3.2 & 3.1 & 1.35 \\
\hline \multirow[t]{2}{*}{10} & Vapor & 0.2 & 0.3 & 0.5 & 0.4 & 0.3 & 0.1 & 0.7 & 0.5 & 0.5 & 0.1 & \\
\hline & Liquid & 4.4 & 4.5 & 0.2 & 0.2 & 0.3 & 0.3 & 0.2 & 0.2 & 0.3 & 0.2 & 1.08 \\
\hline \multirow[t]{2}{*}{11} & Vapor & 0.3 & 0.3 & 0.5 & 0.5 & 0.6 & 0.6 & 0.4 & 0.4 & 0.1 & 0.4 & \\
\hline & Liquid & 8.7 & 10.4 & 0.2 & 0.2 & 0.3 & 0.2 & 0.2 & 0.2 & 0.3 & 0.3 & 2.10 \\
\hline \multirow[t]{2}{*}{12} & Vapor & 0.3 & 0.4 & 0.1 & 0.0 & 0.1 & 0.3 & 0.8 & 0.7 & 0.2 & 0.3 & \\
\hline & Liquid & 6.8 & 6.9 & 7.3 & 5.7 & 4.0 & 3.9 & 0.2 & 0.2 & 2.3 & 2.1 & 3.84 \\
\hline
\end{tabular}

(a) Solution composition: $3.5 \mathrm{M} \mathrm{H}_{2} \mathrm{SO}_{4}$ in which $20 \mathrm{~g}$ per liter of Type 304 ELC stainless steel was dissolved. Solution was not purposely aerated.

(b) g indicares a small gain in weighr. 


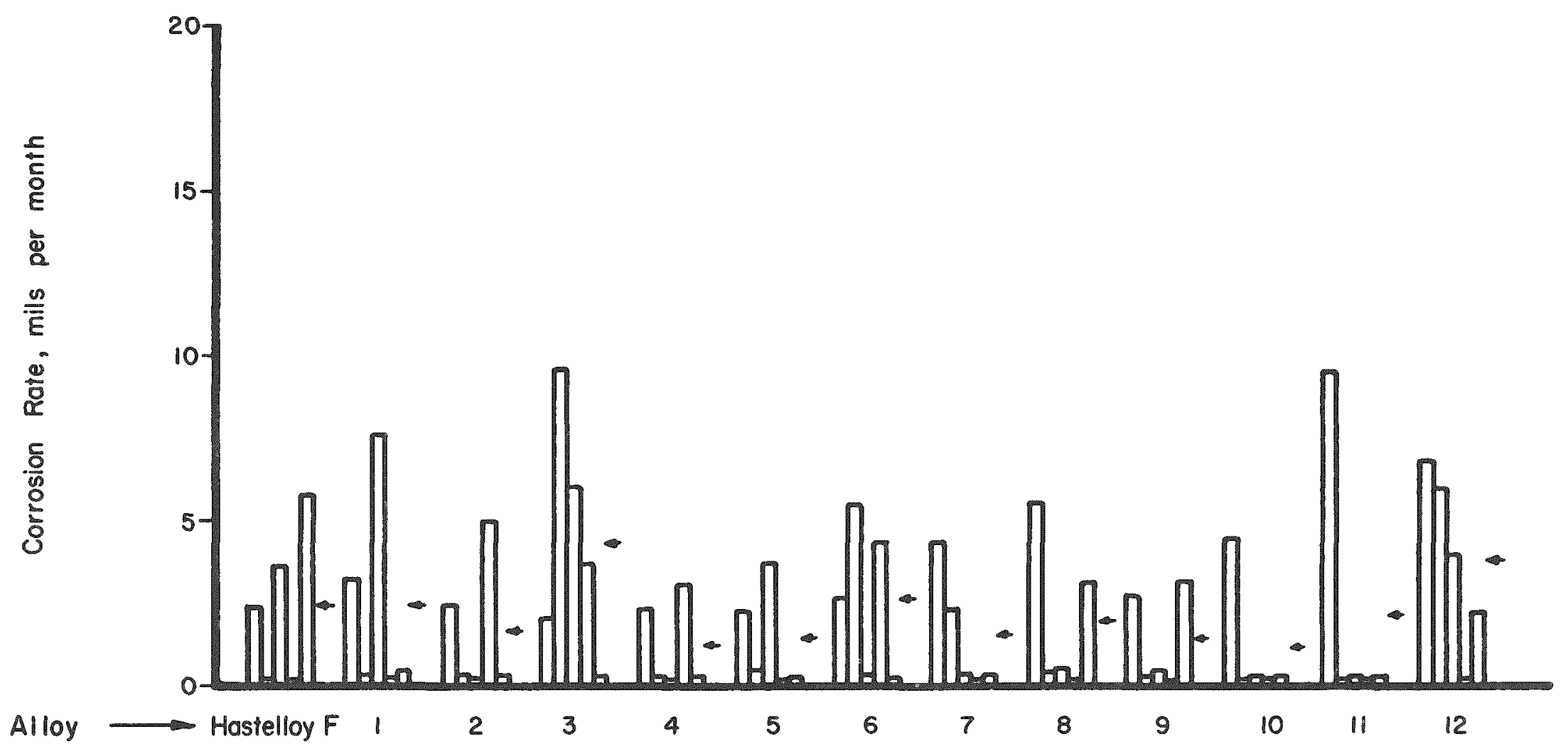

FIGURE 3. CORROSION OF UNWELDED HASTELLOY F AND EXPERIMENTAL ALLOY SPECIMENS OF THE FIRST SERIES UPON EXPOSURE TO SULFEX SOLUTION

Unwelded coupons were submerged in nonaerated boiling solutions. Average rates for duplicate specimens for each $24-\mathrm{hr}$ period are shown. Arrows indicate over-all average. 


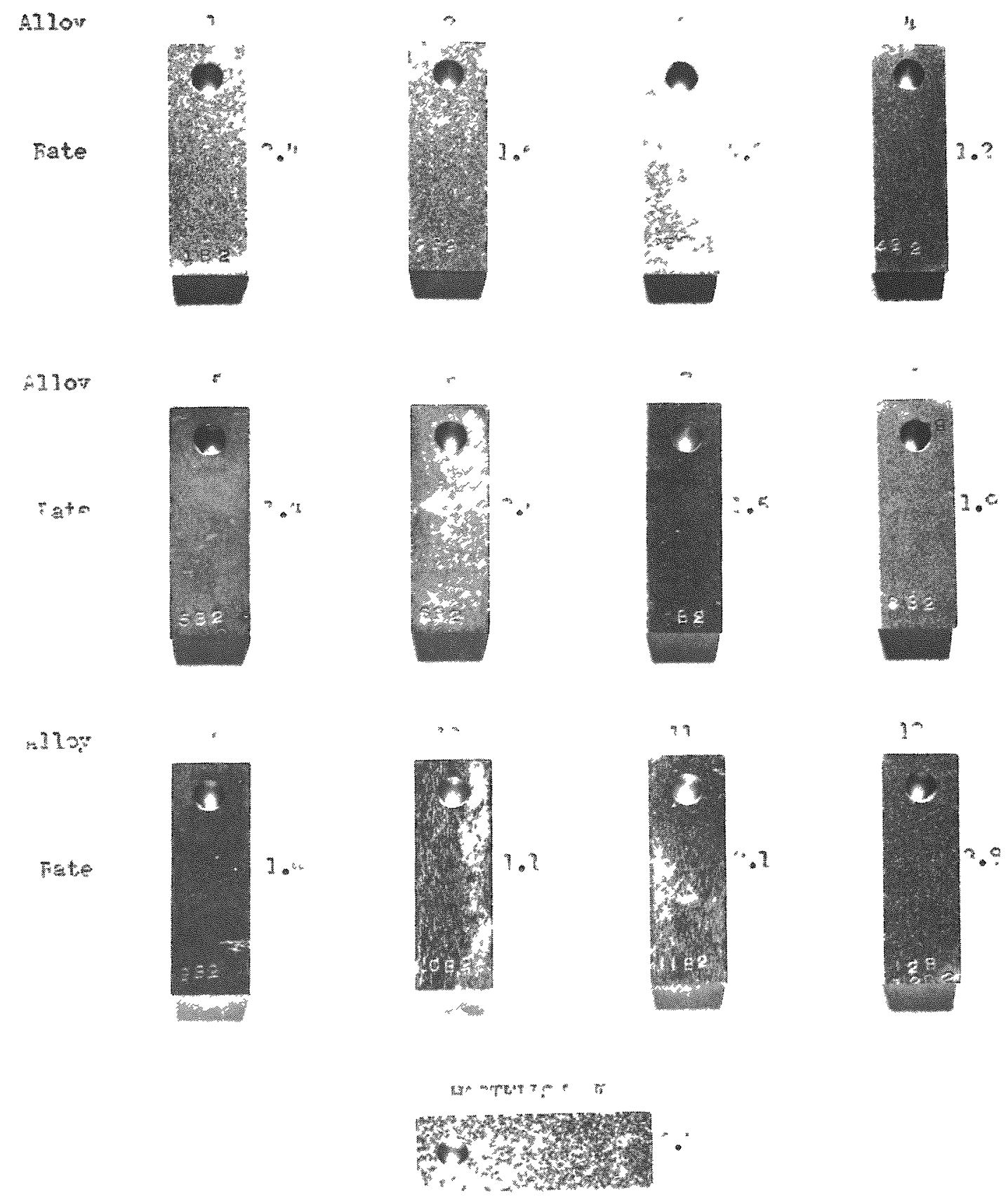

N65337

FIGURE 4. UNWELDED SPECIMENS OF HASTELLOY FND EXPERIMENTAL ALLOY OF THE FRTT SERIES AFTER EXPOSURE TO SULFEX SOLUTION

Specimens were submerged in nonatrated boiling solutions. Corrosion rates, given in mils per month, are average values for duplicate specimens exposed over five 24 -hr periods. 
TABLE 9. CORROSION RATES OF UNWELDED SPECIMENS OF THE FIRST SEPIES UPON PEPOSUPE TO BOLLNG NIFLFX SOLUTIONS(A)

\begin{tabular}{|c|c|c|c|c|c|c|c|c|c|c|c|c|}
\hline \multirow{3}{*}{ Alloy } & \multirow{3}{*}{$\begin{array}{c}\begin{array}{c}\text { Specimen } \\
\text { Position }\end{array} \\
\text { Vapor }\end{array}$} & \multicolumn{11}{|c|}{ Corrosion Rate Each 24-Hr Periud. mils per month } \\
\hline & & \multicolumn{2}{|c|}{ First } & \multicolumn{2}{|c|}{ Second } & \multicolumn{2}{|c|}{ Third } & \multicolumn{2}{|c|}{ Fourth } & \multicolumn{2}{|c|}{ Fifn } & \multirow[t]{2}{*}{ Liquad Arerage } \\
\hline & & 28 & 28 & 34 & 43 & 50 & 61 & 65 & 80 & 95 & 107 & \\
\hline $\mathrm{F}$ & Liquid & 38 & 39 & 44 & 44 & 60 & 62 & 82 & 88 & 108 & 111 & 67.6 \\
\hline \multirow[t]{2}{*}{1} & Vapor & 45 & 41 & 74 & 62 & 76 & 63 & 52 & 61 & 65 & 68 & \\
\hline & Liquid & 50 & 49 & 59 & 55 & 68 & 62 & 70 & 64 & 62 & 62 & 60.8 \\
\hline \multirow[t]{2}{*}{2} & Vapor & 51 & 40 & 83 & 56 & 84 & 71 & 76 & 61 & 75 & 55 & \\
\hline & Liquid & 49 & 46 & 67 & 58 & 81 & 68 & 81 & 68 & 77 & 66 & 66.1 \\
\hline \multirow[t]{2}{*}{3} & Vapor & 27 & 27 & 28 & 29 & 29 & 29 & 30 & 29 & 34 & 26 & \\
\hline & Liquid & 35 & 37 & 36 & 36 & 36 & 35 & 36 & 36 & 36 & 33 & 35.6 \\
\hline \multirow[t]{2}{*}{4} & Vapor & 32 & 31 & 38 & 44 & 34 & 34 & 42 & 36 & 41 & 54 & \\
\hline & Liquid & 40 & $\Delta 1$ & 40 & 41 & 41 & 43 & 40 & 42 & 39 & $\$ 1$ & 40.8 \\
\hline \multirow[t]{2}{*}{5} & Vapor & 37 & 34 & 37 & 41 & 38 & 38 & 35 & 40 & 39 & 40 & \\
\hline & Liquid & 59 & 69 & 65 & 68 & 64 & 65 & 63 & 65 & 64 & 62 & 64.6 \\
\hline \multirow[t]{2}{*}{6} & Vapor & 39 & 39 & 38 & 41 & 36 & 34 & 43 & 45 & 34 & 35 & \\
\hline & Liquid & 67 & 63 & 65 & 63 & 65 & 63 & 63 & 60 & 62 & 56 & 62.7 \\
\hline \multirow[t]{2}{*}{7} & Vapor & 48 & 31 & 88 & 94 & 74 & 71 & 83 & 75 & 30 & 75 & \\
\hline & Liquid & 51 & 55 & 72 & 83 & 82 & 89 & 82 & 87 & 85 & 81 & 70.4 \\
\hline \multirow[t]{2}{*}{8} & Vapor & 50 & 62 & 77 & 72 & 91 & 95 & 100 & 61 & 97 & 76 & \\
\hline & Liquid & 46 & 56 & 80 & 99 & 92 & 101 & 92 & 101 & 90 & 98 & 85.5 \\
\hline \multirow[t]{2}{*}{9} & Vapor & 39 & 35 & 61 & 45 & 77 & 39 & 48 & 41 & 49 & 45 & \\
\hline & Liquid & 55 & 51 & 57 & 49 & 54 & 49 & 51 & 52 & 58 & 56 & 52.6 \\
\hline \multirow[t]{2}{*}{10} & Vapor & 27 & 28 & 30 & 31 & 21 & 32 & 31 & 33 & 33 & 31 & \\
\hline & Liquid & 35 & 35 & 35 & 35 & 36 & 34 & 35 & 39 & 36 & 34 & 35.4 \\
\hline \multirow[t]{2}{*}{11} & Vapor & 28 & 28 & 34 & 30 & 34 & 34 & 32 & 35 & 38 & 36 & \\
\hline & Liquid & 39 & 39 & 39 & 45 & 40 & 40 & 40 & 38 & 38 & 37 & 39.5 \\
\hline \multirow[t]{2}{*}{12} & Vapor & 42 & 41 & 53 & 46 & 69 & 51 & 49 & 58 & 55 & 50 & \\
\hline & Liquid & 64 & 68 & 57 & 61 & 61 & 58 & 60 & 57 & 60 & 59 & 60.5 \\
\hline
\end{tabular}

(a) Solution composition: $1.0 \mathrm{M} \mathrm{HNO}_{3}, 2.0 \mathrm{M} \mathrm{HF}$. 


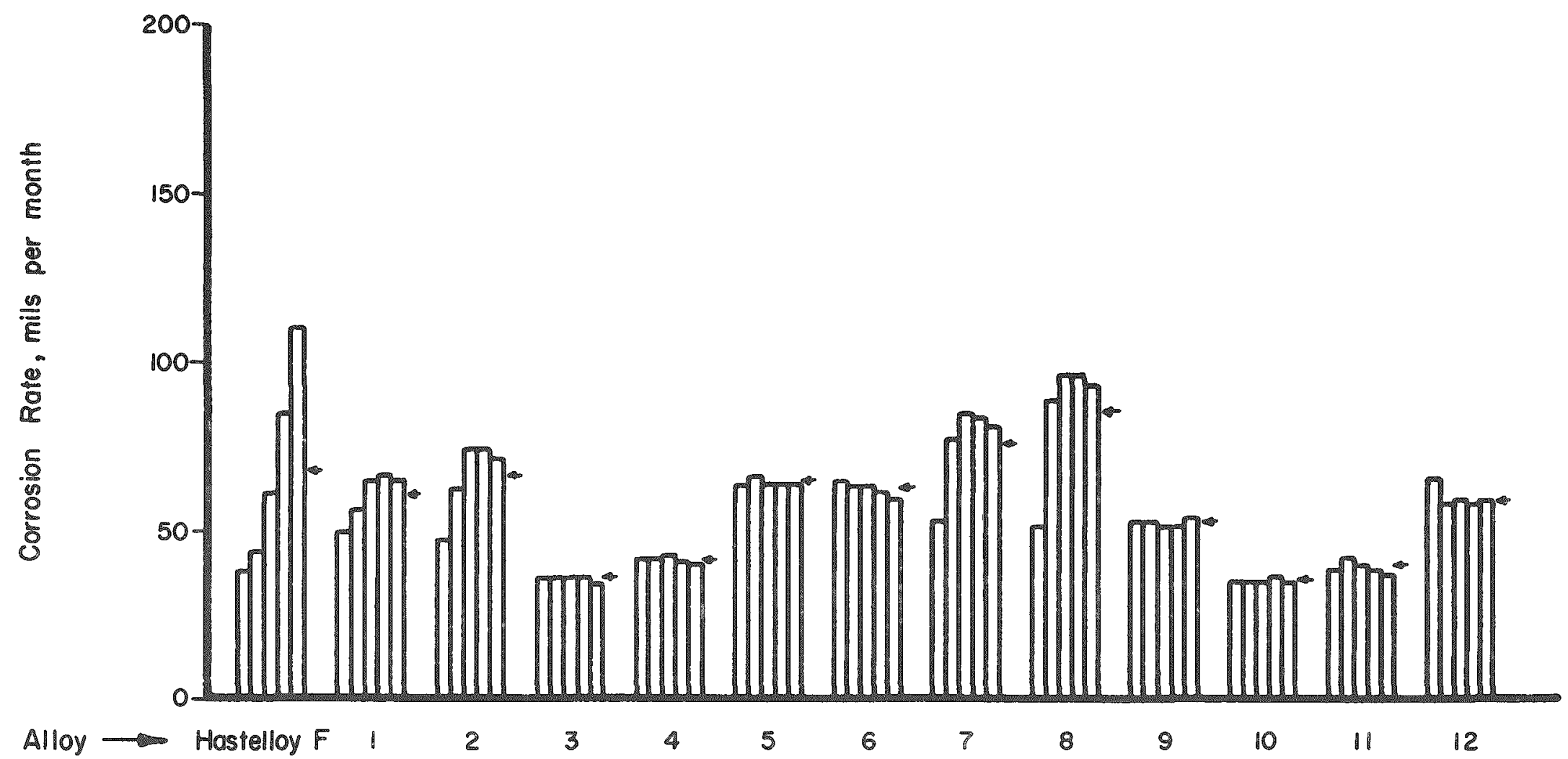

FIGURE 5. CORROSION OF UNWELDED HASTELLOY F AND EXPERIMENTAL ALLOY SPECIMENS OF THE FIRST SERIES UPON EXPOSURE TO NIFLEX SOLUTION

Unwelded coupons were submerged in nonaerated boiling solutions. Average rates for duplicate specimens for each 24-hr period axe shown. Arrows indicate over-all average. 
TABLE 10. CORROSION RATES OF HASTELLOY F SPECIMENS WITH WELDMENTS OF EXPERIMENTAL ALLOYS OF THE FIRST SERIES UPON EXPOSURE TO BOILING SULFEX SOLUTIONS( $($ )

\begin{tabular}{|c|c|c|c|c|c|c|c|c|c|c|c|c|}
\hline \multirow{4}{*}{$\begin{array}{l}\begin{array}{l}\text { Eiller } \\
\text { Alloy }\end{array} \\
\text { Hastelloy } \\
\text { F }\end{array}$} & \multirow{3}{*}{$\begin{array}{c}\begin{array}{c}\text { Specimen } \\
\text { Position }\end{array} \\
\text { Vapor }\end{array}$} & \multicolumn{11}{|c|}{ Corrosion Rate Each 24-Hr Period, mils per month } \\
\hline & & \multicolumn{2}{|c|}{ First } & \multicolumn{2}{|c|}{ Second } & \multicolumn{2}{|c|}{ Third } & \multicolumn{2}{|c|}{ Fourth } & \multicolumn{2}{|c|}{ Fifth } & \multirow[t]{2}{*}{ Liquid Average } \\
\hline & & 0.3 & 0.5 & 0.9 & 0.6 & 0.6 & 0.7 & 0.2 & 0.2 & 0.1 & 0.6 & \\
\hline & Liquid & 1.0 & 1.0 & 0.8 & 0.9 & 0.5 & 0.5 & 3.5 & 3.4 & 0.3 & 0.3 & 1.2 \\
\hline \multirow[t]{2}{*}{1} & Vapor & 1.1 & 0.9 & 0.5 & 0.4 & 0.4 & 0.3 & $g^{(b)}$ & 0.1 & 0.6 & 0.8 & \\
\hline & Liquid & 1.2 & 1.2 & 0.4 & 0.4 & 5.2 & 5.2 & 4.5 & 4.7 & 0.3 & 0.3 & 2.3 \\
\hline \multirow[t]{2}{*}{2} & Vapor & 0.3 & 0.3 & 0.4 & 0.5 & 0.3 & 0.3 & 0.3 & $\mathrm{~g}$ & 0.7 & 1.2 & \\
\hline & Liquid & 7.5 & 7.6 & 0.2 & 0.3 & 9.7 & 9.5 & 2.9 & 2.8 & 0.3 & 0.3 & 4.1 \\
\hline \multirow[t]{2}{*}{3} & Vapor & 0.2 & 0.0 & 0.6 & 0.5 & 0.3 & 0.4 & 0.6 & 0.5 & 0.6 & 0.6 & \\
\hline & Liquid & 3.9 & 4.4 & 0.4 & 0.5 & 11.0 & 10.7 & 0.3 & 0.3 & 0.2 & 0.2 & 3.2 \\
\hline \multirow[t]{2}{*}{4} & Vapor & 0.6 & 0.7 & 0.6 & 0.5 & 0.5 & 0.3 & 0.5 & 0.5 & 0.7 & 0.6 & \\
\hline & Liquid & 1.5 & 1.5 & 0.8 & 0.7 & 6.1 & 6.5 & 0.3 & 0.3 & 0.2 & 0.2 & 1.8 \\
\hline \multirow[t]{2}{*}{5} & Vapor & 0.9 & 0.8 & 0.4 & 0.0 & 0.6 & 0.6 & 0.8 & 0.5 & 0.5 & 0.5 & \\
\hline & Liquid & 1.1 & 1.1 & 0.8 & 0.7 & 0.4 & 0.4 & 0.8 & 0.7 & 0.3 & 0.3 & 0.66 \\
\hline \multirow[t]{2}{*}{6} & Vapor & 0.2 & 0.2 & 0.1 & 0.0 & 0.4 & 0.0 & 0.5 & 0.6 & 0.5 & 0.6 & \\
\hline & Liquid & 1.3 & 1.3 & 6.1 & 6.2 & 7.4 & 7.2 & 0.3 & 0.3 & 0.2 & 0.2 & 3.1 \\
\hline \multirow[t]{2}{*}{7} & Vapor & 0.7 & 0.0 & 0.1 & 0.1 & 0.7 & 0.6 & 0.5 & 0.4 & 0.6 & 0.6 & \\
\hline & Liquid & 0.9 & 1.0 & 3.6 & 3.9 & 0.4 & 0.4 & 0.2 & 0.2 & 0.2 & 0.2 & 1.1 \\
\hline \multirow[t]{2}{*}{8} & Vapor & 0.5 & 0.6 & 0.6 & 0.7 & 0.4 & 0.7 & 0.4 & 0.5 & 0.5 & 0.5 & \\
\hline & Liquid & 1.3 & 1.3 & 2.6 & 2.7 & 0.4 & 0.5 & 0.2 & 0.2 & 0.3 & 0.3 & 1.0 \\
\hline \multirow[t]{2}{*}{9} & Vapor & 0.6 & 0.6 & 0.2 & 0.2 & 0.6 & 0.3 & 0.1 & 0.1 & 0.1 & 0.1 & \\
\hline & Liquid & 1.2 & 2.4 & 3.3 & 3.4 & 0.4 & 0.4 & 9.7 & 10.4 & 0.3 & 0.3 & 3.2 \\
\hline \multirow[t]{2}{*}{10} & Vapor & 0.9 & 0.7 & 0.9 & 1.0 & 0.8 & 0.7 & 0.1 & 0.2 & 0.5 & 0.4 & \\
\hline & Liquid & 1.2 & 1.2 & 0.4 & 0.4 & 1.0 & 0.8 & 4.7 & 3.9 & 1.6 & 1.4 & 1.7 \\
\hline \multirow[t]{2}{*}{11} & Vapor & 0.5 & 0.5 & 0.7 & 1.0 & 0.6 & 0.5 & 0.4 & 0.4 & 0.3 & 0.2 & \\
\hline & Liquid & 1.3 & 1.2 & 0.6 & 0.7 & 0.6 & 0.6 & 0.5 & 0.4 & 0.2 & 0.2 & 0.63 \\
\hline \multirow[t]{2}{*}{12} & Vapor & 0.5 & 0.5 & 0.6 & 0.4 & 0.8 & 0.9 & 0.4 & 0.2 & 0.2 & 0.4 & \\
\hline & Liquid & 1.0 & 1.0 & 0.9 & 1.0 & 0.4 & 0.5 & 6.1 & 5.9 & 0.5 & 0.6 & 1.8 \\
\hline
\end{tabular}

(a) Solution composition: $3.5 \mathrm{M} \mathrm{H}_{2} \mathrm{SO}_{4}$ in which $20 \mathrm{~g}$ per liter of Type 304 ELC stainless steel was dissolved. Solution was not purposely aerated.

(b) g indicates a small gain in weight. 


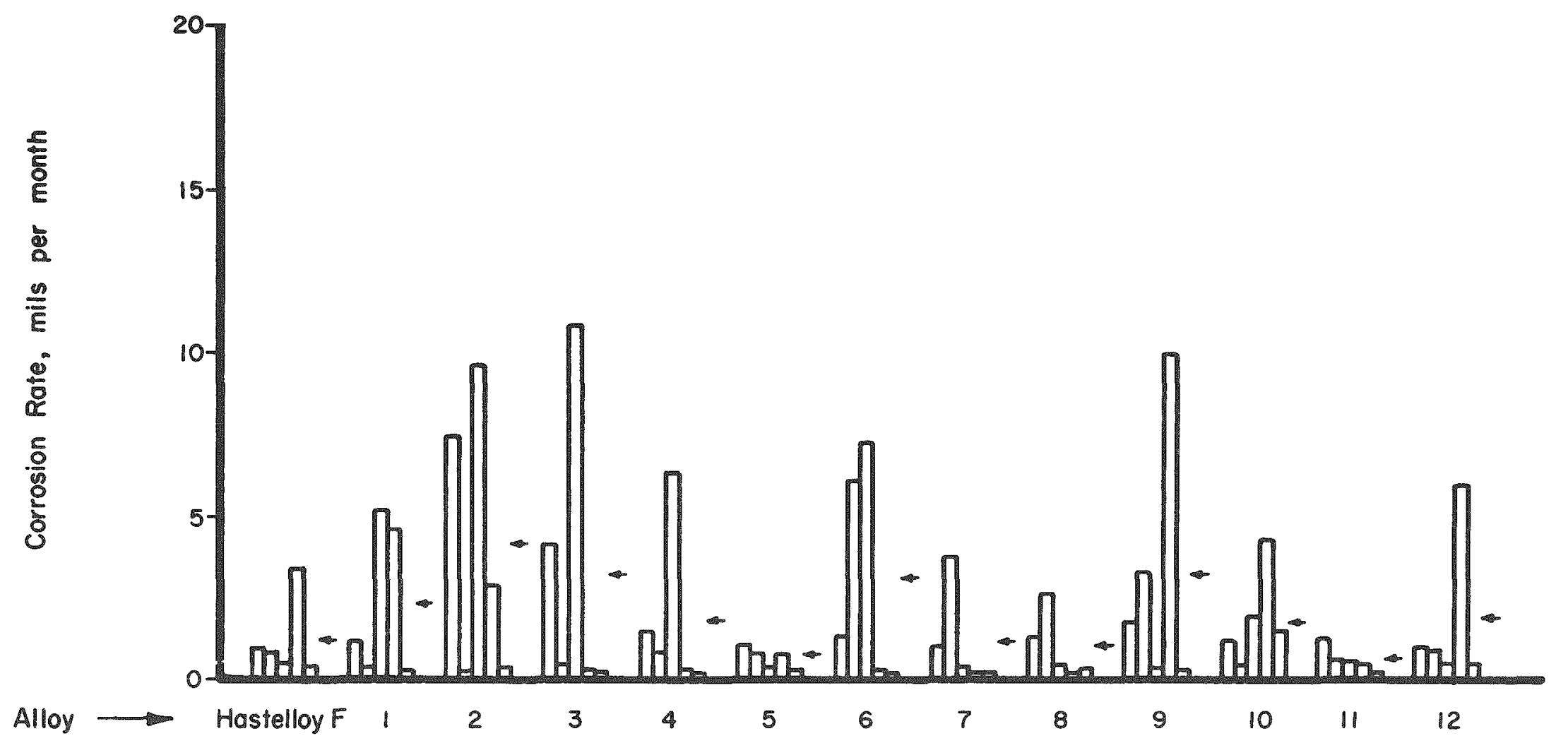

FIGURE 9. CORROSION OF HASTELLOY F SPECIMENS WITH WELDMENTS OF EXPERIMENTAL ALLOYS OF THE FIRST SERIES UPON EXPOSURE TO SULFEX SOLUTION

Specimens were submerged in nonaerated boiling solutions. Avexage rate for duplicate specimens for each 24-hr period are shown. Arrows indicate over-all average. 


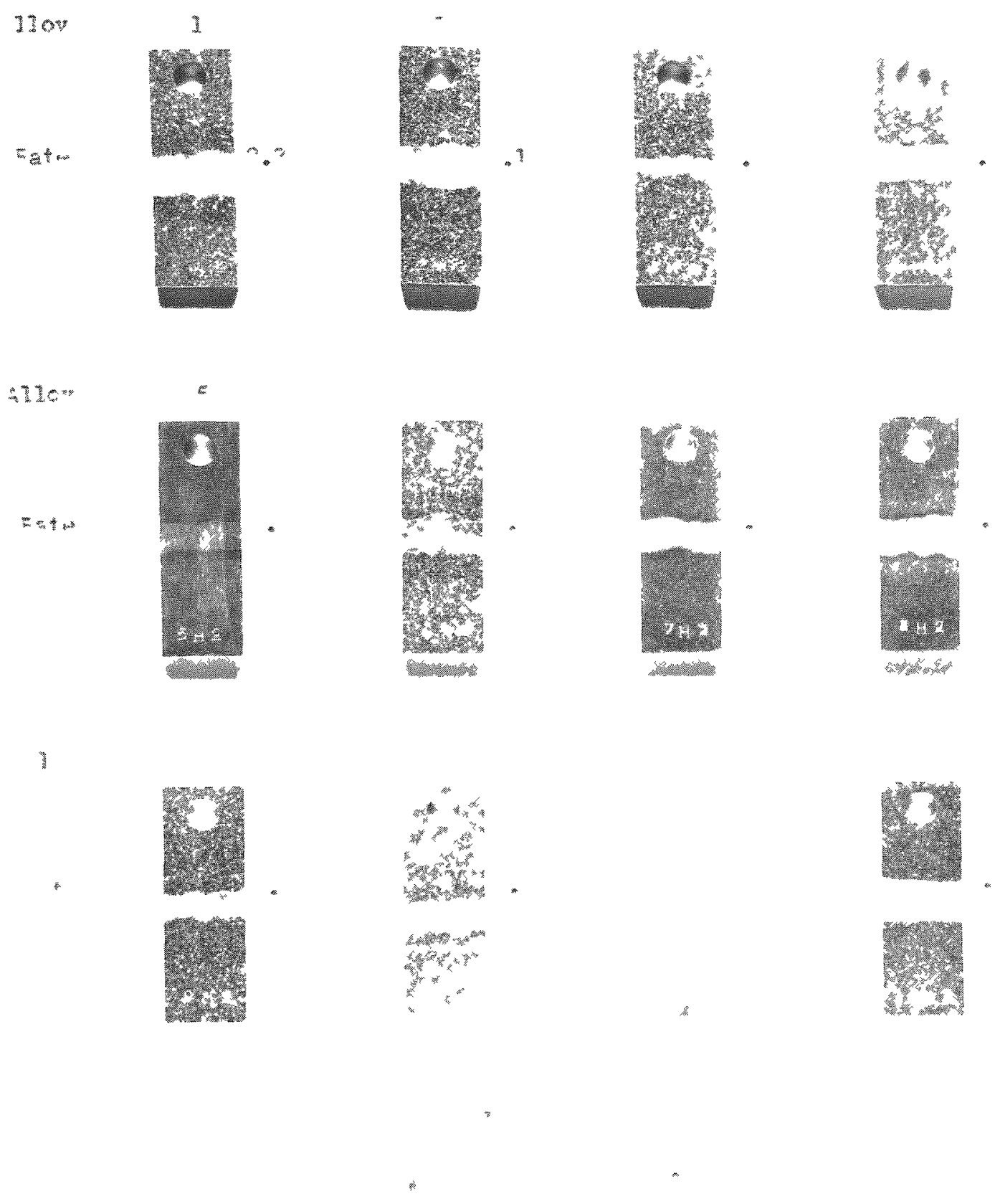

N65339

FIGURE 10. HASTELLOY F SPECIMENS WITH WELDMENTS OF EXPERMMENTAL ALLOYS OF THE FIRST SERIES AFTER EXPOSURE TO SULFEX SOLUTION

Specimens were submerged in nonaerated bollng solutions. Corrosion rates, given in mils per month, are average values for duplicate specimens exposed over five 24 -hr periods. 
TABLE 11. CORROSION RATES OF HASTELLOY $F$ SPECIMENS WITH WELDMENTS OF EXPERI MENT AL ALLOYS OF THE FIRST SERIES UPON EXPOSURE TO BOILING NIF LEX SOLUTION(a)

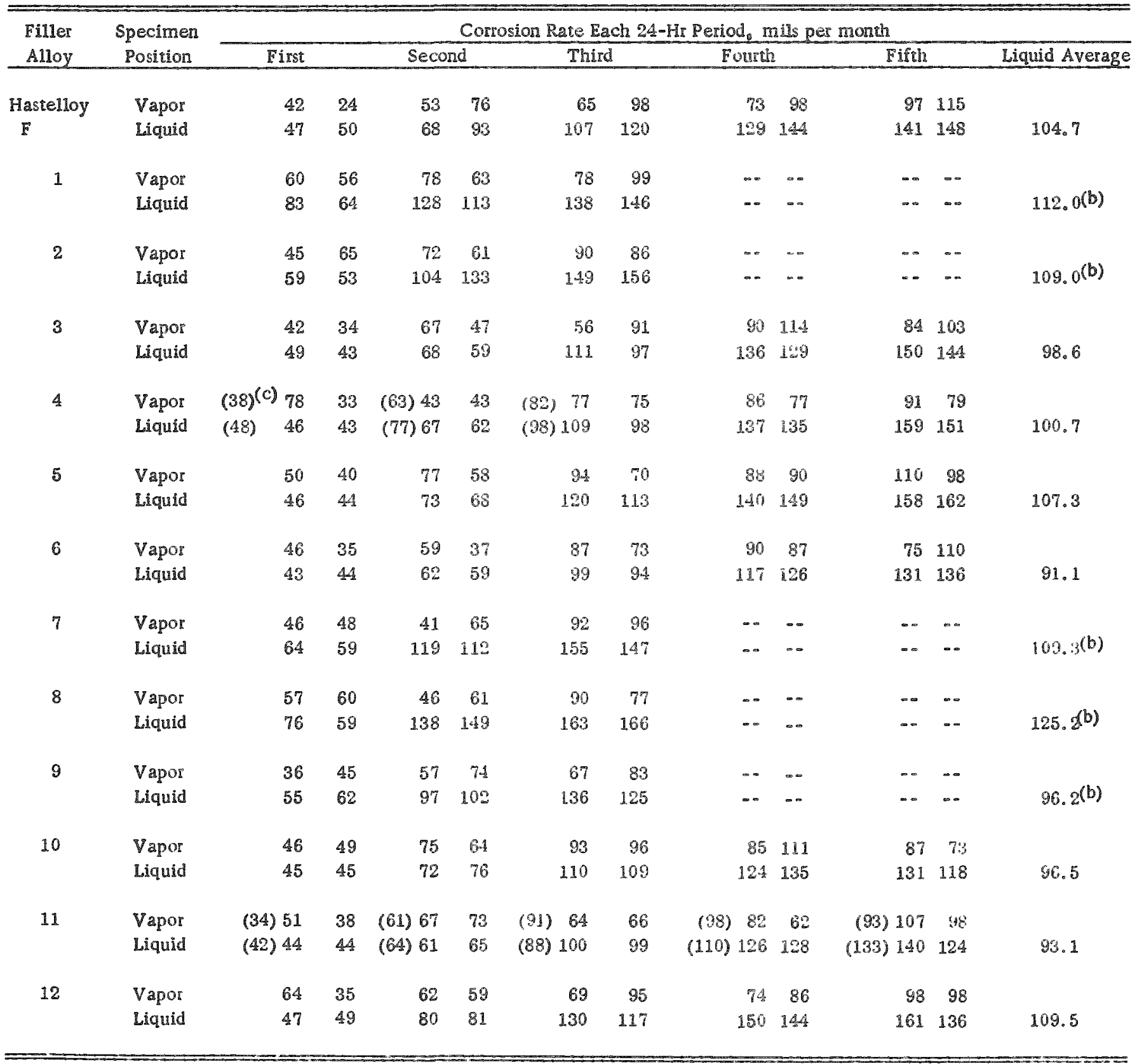

(a) Solution composition: $1.0 \mathrm{M} \mathrm{HNO}_{3}, 2.0 \mathrm{MH}$.

(b) These weldments were perforated after three exposure periods: therefore, the avergge is based on thee periods.

(c) Values in parentheses are for a third set of specimens (see revi). 


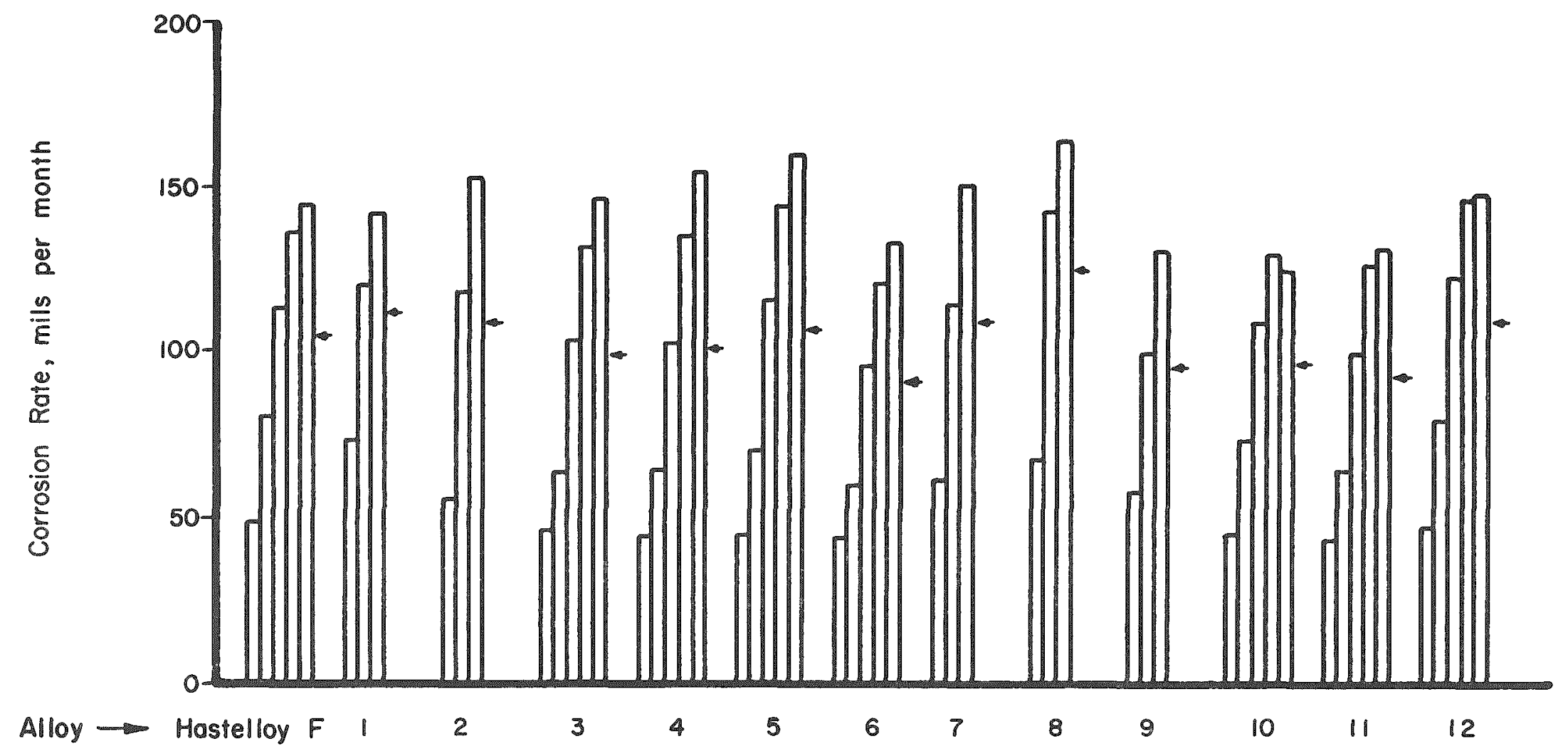

FIGURE 11. CORROSION OF HASTELLOY F SPECIMENS WITH WELDMENTS OF EXPERIMENTAL ALLOYS OF THE FIRST SERIES UPON EXPOSURE TO NIFLEX SOLUTION

Specimens were submerged in nonaerated boiling solutions. Average rates for duplicate specimens for each 24-hr period are shown. Arrows indicate over-all average. Note that poorer specimens were removed after three periods. 


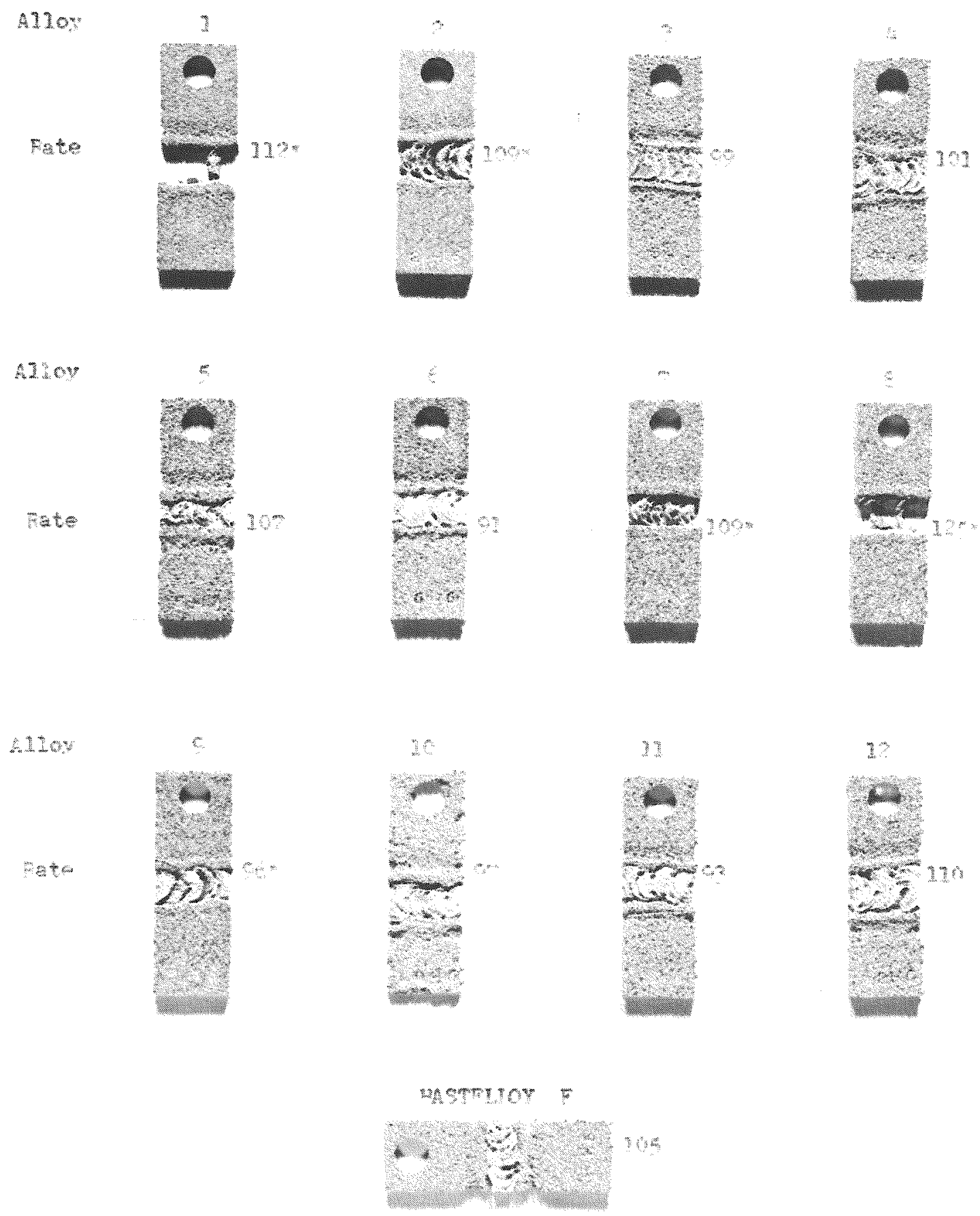

N65334

FIGURE 12. HASTELLOY F SPECIMENS WITH WELDMENTS OF EXPERIMENTAL ALLOYY OF THE FIRST SERIES AFTER EXPOSURE TO NIFLEX SOLUTION

Specimens were submerged in nonaerated boiling solutions. Corrosion rates, given in mils per month, are average values for duplicate specimens exposed over five 24 -hr periods. 
After conducting similar studies, HAPO reported much better performances with certain of the alloys, especially Alloys 4 and 11. This raised some question as to whether the weldments in the BMI specimens might have been contaminated. More strips of vacuum-melted Hastelloy $F$ (Heat FV 123) were welded with Alloys 4 and 11 under carefully controlled conditions in which little opportunity for contamination occurred. Specimens machined from these strips were then exposed to Niflex solutions. The corrosion rates are shown in parentheses in Table 11. The rates paralleled those of the other analogous specimens and the same type of selective attack in the weldments and in the heat-affected zones occurred. This constituted evidence that the welding procedures were not primarily responsible for the poor performance of the welded Hastelloy $F$ specimens. Evidence presented later indicates the difference in performance may be related to the fact that a different heat of Hastelloy $F$ was used at HAPO.

Self-Welded Specimens of the Experimental Alloys

Coupons were sawed, machined, and surface ground from strips of the various experimental alloys which had been butt welded together using the same alloy as filler metal. Again, the weldments ran across the middle of the specimens and were machined flat prior to exposure. Unwelded coupons of vacuum-melted Hastelloy $F$ (Heat FV 123) were included with each series so that the data could be related to information previously collected.

Sulfex Studies. In the two previous series of Sulfex studies the condition of borderline passivity had obscured the relative merits of one alloy over another in regard to resistance to the Sulfex solutions. It had been established at HAPO that sparging air through the Sulfex solution during the exposures resulted in about a tenfold increase in corrosion rate for most materials over that obtained in the unaerated solution. Envisioned process conditions will probably produce corrosive conditions somewhere between these two extremes, but it was agreed that the air-sparged solutions might provide a better basis for the choice of materials of construction. The reason for the substantial increase in corrosiveness of the Sulfex solutions upon air sparging is not clear. One can speculate that it may be associated with the amount of hexavalent chromium produced from the dissolved stainless steel. Chromium in the hexavalent state has been shown to markedly increase corrosion in nitric acid systems. See, for instance, the effect of hexavalent chromium on the corrosion of $\mathrm{Ni}-\mathrm{O}-\mathrm{nel}$ by Thorex solutions described on pages $\mathrm{B}-7$ to $\mathrm{B}-13$ of $\mathrm{BMI}-1375 .(3)$

The corrosion rates for this set of experiments, shown in Table 12, were obtained in the presence of an air sparge. The solutions were made in the same manner as before. During exposure of the specimens, cylinder air was bubbled through small glass tubes inserted beneath the surfaces of the acid solutions in the flasks. A rate of approximately $0.5 \mathrm{ml}$ of air per $\mathrm{ml}$ of solution per min was maintained.

The corrosion rates of the submerged specimens did indeed increase by about a factor of ten over rates measured in the unaerated solution. Moreover, there were no periods during which the submerged specimens remained passive, although the rates did show some fluctuation from period to period. This is shown graphically in Figure 13. 
TABLE 12. CORROSION RATES OF SELF-WELDED EXPERIMENTAL ALIOY SPECIMENS OF THE FIRST SERIES UPON EXPOSURE TO AERATED, BOILING SULEX SOLUTION(a)

\begin{tabular}{|c|c|c|c|c|c|c|c|c|c|c|c|c|}
\hline \multirow{4}{*}{$\begin{array}{c}\begin{array}{c}\text { Alloy and } \\
\text { Filler }\end{array} \\
1\end{array}$} & \multirow{3}{*}{$\begin{array}{c}\begin{array}{c}\text { Specimen } \\
\text { Position }\end{array} \\
\text { Vapor }\end{array}$} & \multicolumn{11}{|c|}{ Corrosion Rate Each $24-\mathrm{Hr}$ Period, mils per month } \\
\hline & & \multicolumn{2}{|c|}{ First } & \multicolumn{2}{|c|}{ Second } & \multicolumn{2}{|c|}{ Third } & \multicolumn{2}{|c|}{ Fourth } & \multicolumn{2}{|c|}{ Fifth } & \multirow[t]{2}{*}{ Liquid Average } \\
\hline & & 0.2 & 0.2 & 0.1 & 0.0 & $g^{(b)}$ & 0.0 & 0.2 & 0.0 & 0.0 & $\mathrm{~g}$ & \\
\hline & Liquid & 12. & 13. & 37. & 36. & 51. & 48. & 21. & 19. & 24. & 23. & 28.4 \\
\hline \multirow[t]{2}{*}{2} & Vapor & 0.1 & 0.1 & 0.0 & 0.1 & 0.0 & 0.0 & 0.1 & 0.1 & 0.2 & 0.0 & \\
\hline & Liquid & 14. & 13. & 19. & 19. & 7.7 & 8.0 & 29. & 29. & 14 & 14. & 16.7 \\
\hline \multirow[t]{2}{*}{3} & Vapor & 0.1 & 0.2 & 0.0 & 0.0 & 0.0 & 0.0 & 0.0 & 0.0 & 0.0 & 0.0 & \\
\hline & Liquid & 15. & 15. & 20 & 20 & 24. & 24. & 14. & 14. & 23. & 22 & 19.1 \\
\hline \multirow[t]{2}{*}{$\frac{4}{4}$} & Vapor & 0.0 & 0.1 & 0.0 & $\mathrm{~g}$ & 0.1 & 0.8 & 0.5 & 0.4 & 0.6 & 0.7 & \\
\hline & Liquid & 19. & 18. & 25. & 24 & 22. & 22. & 13. & 13. & 7.0 & 7.6 & 17.1 \\
\hline \multirow[t]{2}{*}{5} & Vapor & 0.0 & 0.0 & 0.0 & 0.1 & 0.0 & 0.0 & 0.2 & $g$ & 0.4 & 0.6 & \\
\hline & Liquid & 15. & 15 & 15. & 15. & 17. & 17. & 16. & 18. & 10 & 10 & 14.8 \\
\hline \multirow[t]{2}{*}{6} & Vapor & 0.1 & 0.2 & 0.0 & 0.0 & 0.1 & 0.2 & $g$ & 0.0 & 0.0 & 0.0 & \\
\hline & Liquid & 13. & 12. & 20 & 21. & 27. & 26. & 14. & 15. & 16. & 14 & 17.8 \\
\hline \multirow[t]{2}{*}{7} & Vapor & 0.1 & 0.1 & 0.0 & 0.0 & 0.0 & 0.0 & 0.1 & $\mathrm{~g}$ & 0.1 & 0.1 & \\
\hline & Liquid & 14. & 14. & 22 & 24. & 25. & 26. & 20. & 21. & 11. & 11. & 18.8 \\
\hline \multirow[t]{2}{*}{8} & Vapor & 0.2 & 0.2 & 0.1 & 0.0 & 0.0 & 0.0 & 0.0 & 0.3 & 0.0 & 0.1 & \\
\hline & Liquid & 3.8 & 3.7 & 19. & 20 & 21. & 21. & 12. & 12. & 19. & 18. & 15.0 \\
\hline \multirow[t]{2}{*}{9} & Vapor & 0.1 & 0.0 & 0.0 & 0.0 & 0.0 & 0.0 & 0.1 & $\mathrm{~g}$ & 0.3 & 0.4 & \\
\hline & Liquid & 16. & 16. & 16. & 14 & 16. & 16. & 23. & 23. & 9.3 & 9.3 & 15.9 \\
\hline \multirow[t]{2}{*}{10} & Vapor & 0.0 & 0.1 & 0.0 & 0.0 & 0.0 & 0.0 & 0.2 & 0.1 & 0.1 & 0.1 & \\
\hline & Liquid & 18. & 18. & 15. & 14. & 20 & 19. & 20. & 19. & 26. & 26. & 19.5 \\
\hline \multirow[t]{2}{*}{11} & Vapor & 0.0 & 0.0 & 0.0 & 0.0 & 0.0 & 0.0 & 0.1 & $\mathrm{~g}$ & 0.1 & 0.1 & \\
\hline & Liquid & 18. & 19. & 16. & 16. & 30. & 28. & 19. & 19. & 19. & 21. & 20.5 \\
\hline \multirow[t]{2}{*}{12} & Vapor & 0.0 & 0.0 & 0.0 & 0.0 & 0.0 & 0.0 & $\mathrm{~g}$ & 0.1 & 0.4 & 0.1 & \\
\hline & Liquid & 15. & 18. & 17. & 18. & 24. & 24. & 13. & 13. & 11. & 11. & 16.4 \\
\hline Hastelloy & Vapor & 0.3 & 0.3 & 0.0 & 0.0 & 0.0 & 0.0 & 0.3 & 0.3 & 0.5 & 0.4 & \\
\hline $\begin{array}{l}\text { F } \\
\text { (unwelded) }\end{array}$ & Liquid & 0.4 & 0.5 & 15. & 14. & 32. & 33. & 16. & 16. & 17. & 18. & 16.2 \\
\hline
\end{tabular}

(a) Solution composition: $3.5 \mathrm{M} \mathrm{H}_{2} \mathrm{SO}_{4}$ in which $20 \mathrm{~g}$ per liter of Type 304 ELC stainless steel was dissolved. Solutions were aerated with cylinder air at the rate of $0.5 \mathrm{ml}$ of air per $\mathrm{ml}$ of solution per min.

(b) g indicates a small gain in weight. 


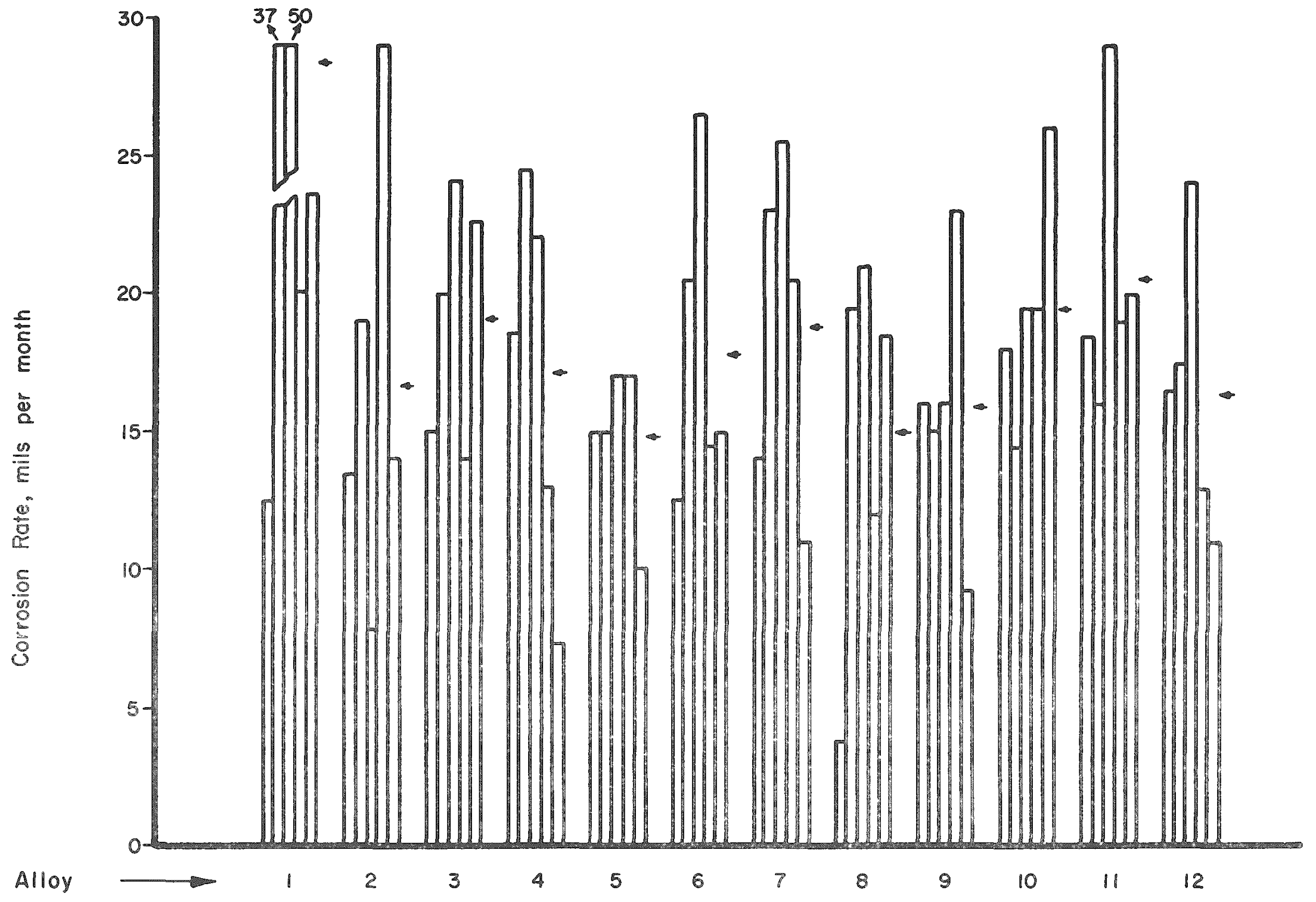

FIGURE 13. CORROSION OF SELF-WELDED EXPLRIMENT AL ALLOYS OF THE FIRST SERIES UPON EXPOSURE TO SULFEX SOLUTION

Specimens were submerged in aerated boiling solutions. Average rates for duplicate specimens for each 24-hr pexiod are shown. Arrow indicates over-all average. 
Even though the corrosion rates were considerably higher than in the other Sulfex studies there was no selective attack of the weldments. The appearance of representative submerged specimens following exposure is shown in Figure 14. The attack on all specimens was fairly uniform. Except for the high rate of Alloy 1, the corrosion rates were sufficiently similar that there is little basis for selecting one alloy in preference to another for Sulfex use.

Niflex Studies. The studies conducted with self-welded specimens in the Niflex solution brought out some significant differences in the resistances of the alloys.

The weldments of the submerged specimens of Alloys 1, 2, 7, and 8 were perforated by the end of three $24 \mathrm{wr}$ exposure periods to boiling Nivlex solution. By the end of five periods, severe localized attack in and around the weldments was evident on the submerged specimens of Alloys 9 and 12, also.

In contrast to the results obtained with Hastelloy $F$ specimens welded with the experimental alloys, self-welded specimens of Alloys 3, 4, 5, 6, 10, and 11 were not selectively attacked. Furthermore, no increased attack occurred in the heat-affected zones on these self-welded specimens. As in the case with the unwelded specimens, the lowest corrosion rates were measured for Alloys 3, 4, 10, and 11. The rates are tabulated in Table 13 and shown graphically in Figure 15. In fact, the bars representing corrosion rates for Alloys 3,4,5, 6, 9, 10, 11, and 12 in Figure 15 can be nearly superimposed on the corresponding bars for the unwelded specimens shown in Figure 5 .

The appearance of representative self-welded, submerged specimens following exposure is shown in $F$ igure 16. While the over-all attack was quite high for all the specimens, the problem of selective attack of the weldments appears to have been overcome by the use of certain of the self-welded alloys.

Miscellaneous Corrosion Studies in

Preparation for the Second

Alloy Series

Several short-term studies in Niflex solution were conducted as adjuncts to the study of the 12 experimental alloys to either help elucidate the corrosion characteristics observed in the experimental alloys or to increase the general knowledge before selecting an additional group of experimental compositions.

Fair corrosion resistance in Niflex solutions for specimens of vacuum-melted Hastelloy $F$ (Heat FV 153) welded with Alloys 3, 4, 10, and 11 had been observed at HAPO. It had also established that the HAPO original stock of vacuum-melted Hastelloy F (Heat FV 150) had significantly better resistance to Niflex solutions than any of the subsequent heats. This was confirmed at BMI, as shown in Table 14. Note that the corrosion rate for the specimen of Heat FV 150 did not show the tendency to increase with continued exposure as did Heat FV 123. The compositional variations of the minor elements in these heats, tabulated on page 39, do not show any striking reason for the differences in resistance unless it is related to the sulfur content. It apparently cannot be ascribed to the carbon content as commercial Hastelloy $F$ with a carbon content of about $0.05 \mathrm{w} / \mathrm{o}$ gave relatively stable corrosion rates, as shown in Table 14. 


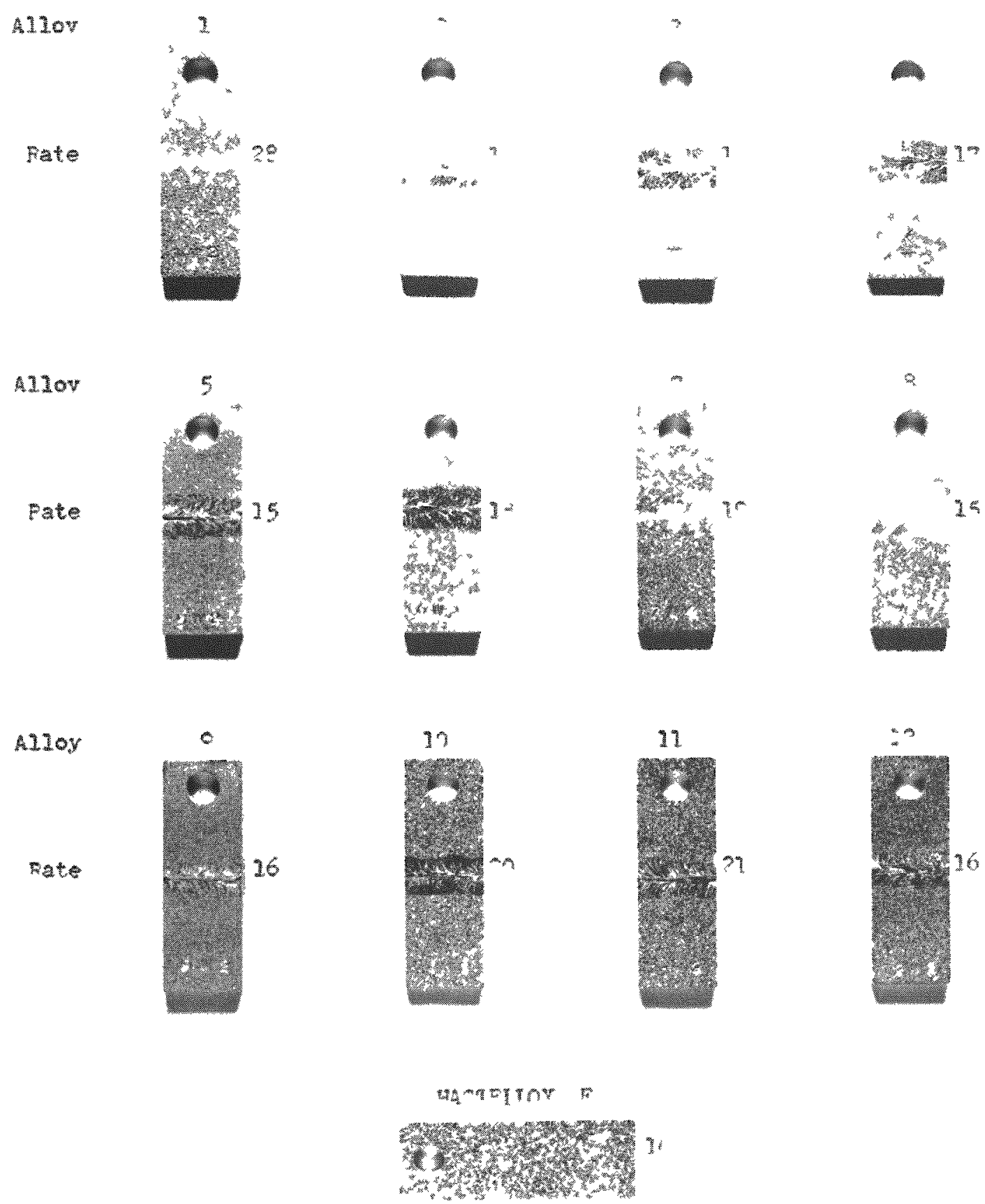

N65336

FIGURE 14. SELF-WELDED SPECIMENS OF EXPERMENTAL ALLOYS OF THE FIRST STRES AFTER EXPOSURE TO AERATED SULFEX SOLU TION

Specimens were subraerged in aerated $(0.5 \mathrm{ml}$ of air per wl of solution per min) boiling solutions. Corrosion rates, given in mils per month, are average values for duplicate specimens exposed over five 24-br periods. 
TABLE 13. CORROSION RATES OF SELF-WELDED EXPERIMENTAL ALLOY SPECIMERS OF IHE FIMST SERIES UPON EXPOSURE TO BOLLING NIFLEX SOLUTION(a)

\begin{tabular}{|c|c|c|c|c|c|c|c|c|c|c|c|c|}
\hline \multirow{4}{*}{$\frac{\text { Alloy and Filler }}{1}$} & \multirow{3}{*}{$\begin{array}{c}\begin{array}{c}\text { Specimen } \\
\text { Posilion }\end{array} \\
\text { Vapor }\end{array}$} & \multicolumn{11}{|c|}{ Corrosion Rare Each $24-H r$ Period, mils per month } \\
\hline & & \multicolumn{2}{|c|}{ First } & \multicolumn{2}{|c|}{ Second } & \multicolumn{2}{|c|}{ Third } & \multicolumn{2}{|c|}{ Fourth } & \multicolumn{2}{|c|}{ Fifth } & \multirow[t]{3}{*}{ Liquid Average } \\
\hline & & 46 & 41 & 80 & 65 & 76 & 54 & $\infty$ & $-\infty$ & $-\infty$ & $=-$ & \\
\hline & Liquid & 60 & 62 & 86 & 87 & 97 & 100 & $-\infty$ & $-\infty$ & $\infty$ & $-\infty$ & \\
\hline \multirow[t]{2}{*}{2} & Vapor & 55 & 42 & 81 & 81 & 58 & 89 & - & $-\infty$ & $=$ & $\ldots$ & \\
\hline & Liquid & 70 & 71 & 112 & 117 & 124 & 120 & -- & -- & $-\infty$ & $-\infty$ & $102.3^{(b)}$ \\
\hline \multirow[t]{2}{*}{3} & Vapor & 32 & 30 & 33 & 26 & 31 & 23 & 25 & 29 & 48 & 42 & \\
\hline & Liquid & 38 & 37 & 38 & 38 & 36 & 38 & 37 & 37 & 38 & 34 & 37.1 \\
\hline \multirow[t]{2}{*}{4} & Vapor & 58 & 30 & 42 & 32 & 35 & 29 & 28 & 20 & 30 & 35 & \\
\hline & Liquid & 41 & 41 & 41 & 41 & 40 & 41 & 40 & 41 & 41 & 39 & 40.6 \\
\hline \multirow[t]{2}{*}{5} & Vapor & 40 & 34 & 37 & 32 & 38 & 33 & 32 & 33 & 35 & 38 & \\
\hline & Liquid & 58 & 57 & 60 & 61 & 61 & 59 & 52 & 57 & 58 & 58 & 58.1 \\
\hline \multirow[t]{2}{*}{6} & Vapor & 38 & 36 & 35 & 37 & 40 & 38 & 43 & 34 & 38 & 39 & \\
\hline & Liquid & 67 & 58 & 61 & 55 & 63 & 58 & 63 & 61 & 59 & 61. & 60.6 \\
\hline \multirow[t]{2}{*}{7} & Vapor & 45 & 55 & 52 & 99 & 80 & 34 & - & $-\infty$ & $-\infty$ & - & \\
\hline & Liquid & 70 & 76 & 104 & 128 & 111 & 121 & $-\infty$ & - & $\ldots$ & -- & $101.7^{(b)}$ \\
\hline \multirow[t]{2}{*}{8} & Vapor & 75 & 65 & 97 & 86 & 112 & 114 & $\infty$ & $\infty$ & $\infty$ & $-\infty$ & \\
\hline & Liquid & 123 & 103 & 170 & 165 & 151 & 158 & -. & -. & $\ldots$ & $\ldots$ & $145.0^{(b)}$ \\
\hline \multirow[t]{2}{*}{9} & Vapor & 39 & 37 & 75 & 46 & 46 & $4 A$ & 48 & 50 & 52 & 47 & \\
\hline & Liquid & 53 & 54 & 52 & 53 & 52 & 55 & 53 & 55 & 54 & 54 & 53.5 \\
\hline \multirow[t]{2}{*}{10} & Vapor & 25 & 28 & 28 & 27 & 31 & 29 & 20 & 33 & 27 & 32 & \\
\hline & Liquild & 36 & 35 & 35 & 35 & 34 & 36 & 36 & 35 & 35 & 33 & 35.0 \\
\hline \multirow[t]{2}{*}{11} & Vapor & 32 & 36 & 29 & 29 & 29 & 23 & 32 & 34 & 34 & 35 & \\
\hline & Liquid & 37 & 37 & 37 & 37 & 37 & 38 & 38 & 38 & 37 & 37 & 37.3 \\
\hline \multirow[t]{2}{*}{12} & Vapor & 37 & 38 & 48 & 43 & 51 & 44 & 59 & 52 & 72 & 54 & \\
\hline & Liquid & 60 & 58 & 60 & 60 & 61 & 61 & 61 & 62 & 64 & 60 & 60.7 \\
\hline \multirow{2}{*}{$\begin{array}{l}\text { Hastelloy } \mathbb{F} \\
\text { (unwelded) }\end{array}$} & Vapor & 35 & 32 & 48 & 38 & 56 & 64 & 93 & 62 & 53 & 74 & \\
\hline & Liquid & 39 & 40 & 44 & 47 & 60 & 67 & 77 & 95 & 100 & 121 & 69.0 \\
\hline
\end{tabular}

(a) Solution composition: $1.0 \mathrm{M} \mathrm{HNO}, 2.0 \mathrm{M} \mathrm{HF}$.

(b) These weldments were perforated afrer three exposure periods. Therefore, the average is based on three periods. 


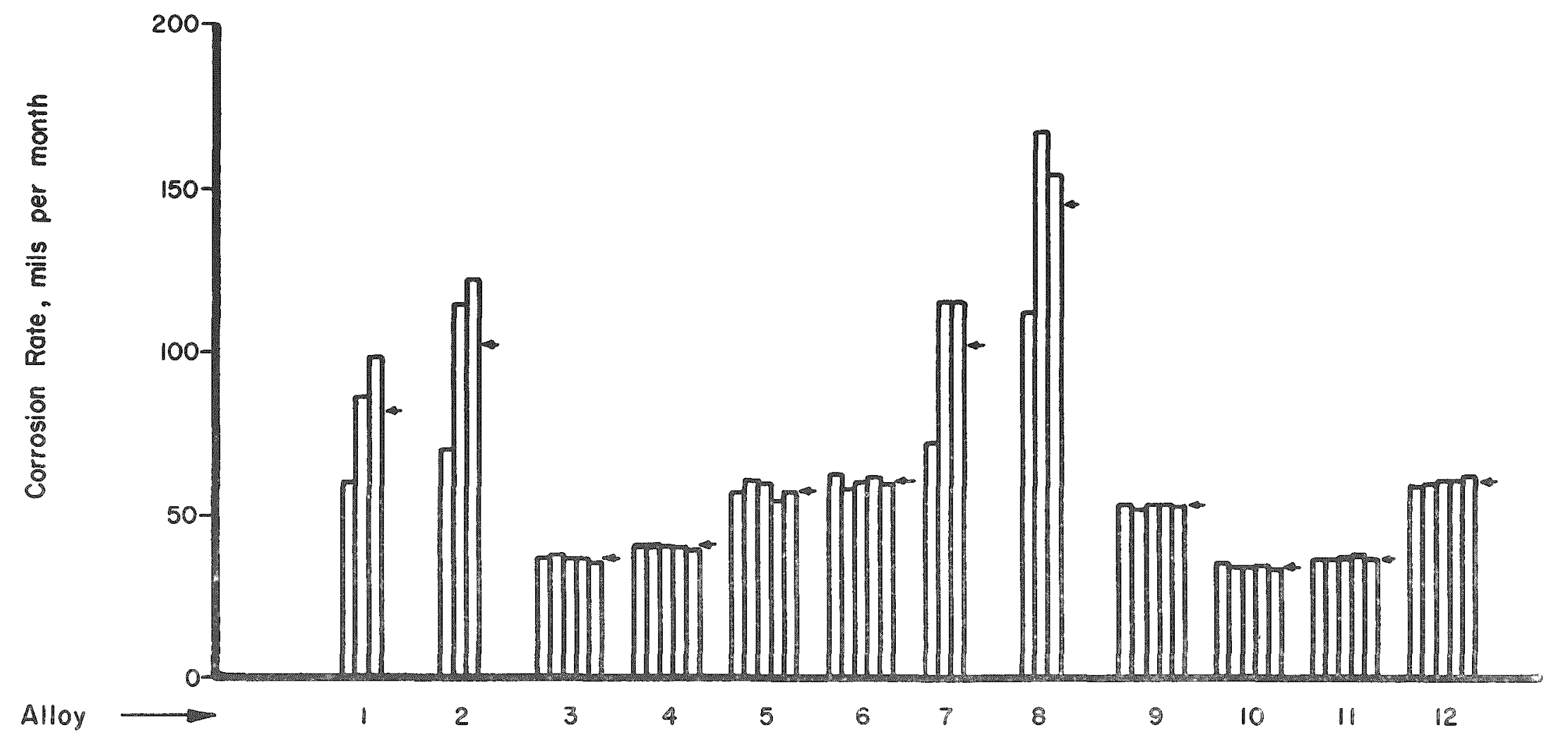

FIGURE 15. CORROSION OF SELE-WELDED EXPERIMENT AL ALLOYS OF THE FIRST SERIES UPON EXPOSURE TO NIFLEX SOLUTION

Specimens were submerged in nonaerated boiling solutions. Average rates for duplicate specimens for each 24-hr period are shown. Arrows indicate over-all average. Note that poorer specimens were removed after three periods. 


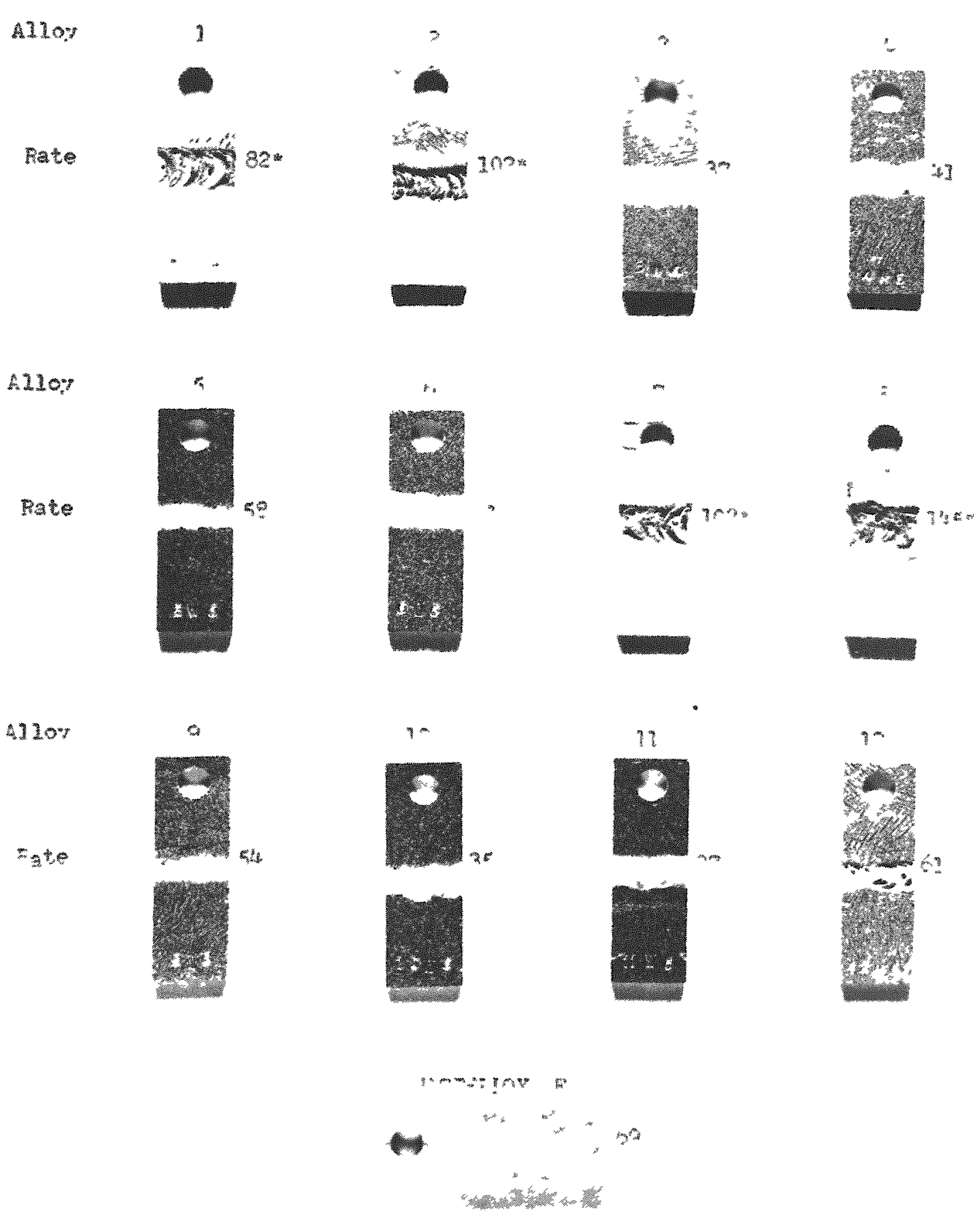

N65335

FIGURE 16. SELF-WELDED SPECIMENS OF EXPERIMENTAL ALLOYS OF THE FIRST SERIES AFTER EXPOSURE TO NIFLEX SOLUTIONS

Specumens were submerged in nonaerated bolling solutions. Corrosion rates, given in mils per month. are average values for duplicate specimens exposed over five 24-hr periods 
TABLE 14. CORROSION RATES OF UNWELDED SPECIMENS OF MISCELLANEOUS ALLOYS UPON EXPOSURE TO BOILING NIF LEX SOLUTION(a)

\begin{tabular}{|c|c|c|c|c|c|c|c|c|c|c|c|c|c|}
\hline \multirow{3}{*}{ Alloy } & \multirow{3}{*}{$\begin{array}{c}\begin{array}{c}\text { Specimen } \\
\text { Position }\end{array} \\
\text { Vapor }\end{array}$} & \multicolumn{12}{|c|}{ Corrosion Rate Each 24-Hr Period, mils per month } \\
\hline & & \multicolumn{2}{|c|}{ First } & \multicolumn{2}{|c|}{ Second } & \multicolumn{2}{|c|}{ Third } & \multicolumn{2}{|c|}{ Fourth } & \multicolumn{2}{|c|}{ Eifth } & \multicolumn{2}{|c|}{ Sixth } \\
\hline & & $-\infty$ & $\infty$ & $-\infty$ & - & $-\infty$ & $-\infty$ & $-\infty$ & -- & $-\infty$ & $-\infty$ & $=$ & $\infty$ \\
\hline $\mathrm{F}(\mathrm{FV} 150)$ & Liquid & 42 & $-\infty$ & 31 & $-\infty$ & 50 & $\infty$ & 39 & $-\infty$ & 41 & -- & -- & -- \\
\hline Hastelloy & Vapor & $-\infty$ & $\infty$ & 34 & $\infty$ & $\infty$ & $\infty$ & $\infty$ & -- & $\infty$ & $-\infty$ & - & -- \\
\hline $\begin{array}{l}\text { F (Commer- } \\
\text { cial) }\end{array}$ & Liquid & 54 & 52 & $-\infty$ & 49 & 52 & 47 & 47 & 46 & 46 & 45 & 49 & 47 \\
\hline Elgiloy & Liquid & 87 & 88 & 118 & 118 & $\operatorname{Rer}$ & noved & $-\infty$ & $\infty$ & -- & $\infty$ & $\infty$ & $=$ \\
\hline ILium 98 & Liquid & 82 & $-\infty$ & 189 & $\infty$ & 236 & $-\infty$ & $\operatorname{Ren}$ & goved & $-\infty$ & $-\infty$ & $-\infty$ & $-\infty$ \\
\hline $\begin{array}{c}\text { Haynes } 21 \\
\text { (rolled) }\end{array}$ & Liquid & 64 & $-\infty$ & 71 & - & 61 & $\infty$ & 54 & -- & 46 & - & $-\infty$ & $\infty$ \\
\hline CDAMCu & Liquid & 140 & $=$ & 228 & - & Rer & hoved & $\infty$ & -- & -. & $-\infty$ & $-\infty$ & $-\infty$ \\
\hline $\begin{array}{l}\text { Hastelloy } \\
\text { F (FV 123) }\end{array}$ & Liquid & 39 & $-\infty$ & 47 & $\infty$ & 67 & $\infty$ & 95 & - & 121 & $\infty$ & $=-$ & $-\infty$ \\
\hline
\end{tabular}

(a) Solution composition: $1.0 \mathrm{M} \mathrm{HNO}_{3}, 2.0 \mathrm{M} \mathrm{HF}$. 


\begin{tabular}{|c|c|c|c|c|c|c|c|c|c|}
\hline \multirow[b]{2}{*}{ Heat } & \multirow{2}{*}{$\begin{array}{l}\text { Relative } \\
\text { Resistance }\end{array}$} & \multicolumn{8}{|c|}{ Composition, w/o } \\
\hline & & $\overline{\mathrm{Nb}}$ & $\mathrm{Mn}$ & $\mathrm{Si}$ & Co & $\mathrm{Cu}$ & $S$ & $\bar{C}$ & $\overline{\mathrm{N}}$ \\
\hline V 150 & Good & 2. 1 & 1.15 & 0.34 & 0.33 & 0.01 & 0.008 & 0.01 & 0.009 \\
\hline FV 153 & Fairly good & 2.3 & 1.60 & 0.39 & 0.19 & 0.06 & 0.007 & 0.02 & $-\infty$ \\
\hline EV 123 & Poor & 1.9 & 1.27 & 0.54 & 0.28 & 0.02 & 0.018 & 0.02 & 0.009 \\
\hline
\end{tabular}

Specimens of Elgiloy (cobalt- $20 \mathrm{w} / 0$ chromium- $15 \mathrm{w} / 0$ nickel- $15 \mathrm{w} / 0$ iron-7 w/o molybdenum $-2 \mathrm{w} / 0$ mangane $-0.05 \mathrm{w} / 0$ carbon $-0.03 \mathrm{w} / 0$ beryllium) did not show good resistance. Neither did Illium 98 (nickel- $26 \mathrm{w} / 0$ chromium $-8 \mathrm{w} / 0$ molybdenum-5 w/o copper $-2.5 \mathrm{w} / 0$ iron- $0.03 \mathrm{w} / 0$ carbon), or CD $4 \mathrm{MCu}$ (iron- $25 \mathrm{w} / 0$ chromium- $3 \mathrm{w} / 0$ copper $-2 \mathrm{w} / 0$ molybdenum- $1 \mathrm{w} / 0$ silicon- $1 \mathrm{w} / 0$ manganese $-0.04 \mathrm{w} / 0$ carbon). However, rolled Haynes 21 (cobalt- $28 \mathrm{w} / 0$ chromium-5 w/o molybdenum- 3 w/o nickel- $2 \mathrm{w} / 0$ iron$0.30 \mathrm{w} / 0$ carbon) showed fair resistance. This alloy, unfortunately, has very poor resistance to Sulfex solutions. (3)

It has already been shown that the weldments of self-welded specimens of Alloy 1 were quickly perforated by Niflex solutions while selective attack was not pronounced in the case of Alloy 4. Specimens of the as-cast material of these two alloys were exposed to boiling Niflex solution for $24 \mathrm{hr}$. The corrosion rates were $401 \mathrm{mils}$ per month for Alloy 1 and 60 mils per month for Alloy 4. This rate of 401 compared to about 60 mils per month for the rolled and annealed structure showed that the cast structure of Alloy 1 was very much more susceptible to attack by Niflex solution. The corroded specimen of as-cast Alloy 1 was very spongy, as if certain areas were much more resistant than others. The metal standing out in relief was scraped off and its composition was found to be lower in molybdenum and niobium than that of the base metal. This is in line with observations of the relationship between resistance to Niflex corrosion and the molybdenum and niobium contents of the experimental alloys.

\section{Conclusions Based on the First Series of Experimental Alloys}

The results of exposure of the various sets of welded and unwelded coupons to Sulfex solution have not provided any good basis for the selection of one experimental alloy over the others. All of the alloys, with the possible exception of Alloy 1, can be expected to bchave reasonably well in Sulfex solutions even when the solutions are aerated.

The Niflex studies indicated that none of the first series of experimental alloys is usciul as a welding material for vacuum-melted Hastelloy $F$, at least for Heat FV 123. However, some of these alloys, when self-welded, were reasonably resistant to Niflex solution. In fact, eight experimental compositions evinced lower rates than the Hastelloy $F$ heat. In Table 15, the average corrosion rates of submerged, self-welded specimens are compared with important compositional variables. The alloys are arranged in order of decreasing resistance to boiling Niflex solution. Only three 24-hr exposure periods were averaged in the case of Niflex solutions so that all alloys could be compared on the same basis. 
TABLE 15. COMPARISONS OF COMPOSITIONAL VARIABLES AND CORROSION RATES FOR SEL $F$ WELDED SPECIMENS OF THE FIRST SERIES SUBMERGED IN BOILING NIFLEX(a) OR AERATED SULEX(b) SOLUTIONS

\begin{tabular}{|c|c|c|c|c|c|c|}
\hline \multirow[b]{2}{*}{ Alloy ${ }^{(c)}$} & \multicolumn{2}{|c|}{$\begin{array}{l}\text { Corrosion Rate, } \\
\text { mils per month } \\
\end{array}$} & \multicolumn{4}{|c|}{ Intended Alloy Addition, w/o } \\
\hline & Niflex $(d)$ & Sulfex $(e)$ & Mo & $\mathrm{Cu}$ & $\mathrm{Nb}$ & $\mathrm{Ti}$ \\
\hline 10 & 35.2 & 19.5 & 6 & 2 & $\infty$ & $-\infty$ \\
\hline 11 & 37.2 & 20.5 & 6 & 2 & $\infty$ & 1 \\
\hline 3 & 37.5 & 19.1 & 6 & $\infty$ & $\ldots$ & 0.5 \\
\hline 4 & 40.8 & 17.1 & 6 & $\infty$ & $\infty$ & 1 \\
\hline 9 & 53.2 & 15.9 & 3 & 1 & 2 & $=$ \\
\hline 5 & 59.3 & 14.8 & 3 & 2 & $\Rightarrow$ & 0.5 \\
\hline 12 & 60.0 & 16.4 & 3 & 2 & 2 & $-\infty$ \\
\hline 6 & 60.3 & 17.8 & 3 & 2 & 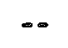 & 1 \\
\hline Hastelloy $\mathbb{F}$ & 80.8 & 16.2 & 6.4 & 0.02 & 1.4 & $\infty$ \\
\hline 1 & $82.0^{(I)}$ & 28.4 & 6 & 1 & 2 & $\infty$ \\
\hline 7 & 102. (I) & 18.8 & 6 & 3 & 2 & $\infty$ \\
\hline 2 & 102. (f) & 16.7 & 6 & 2 & 2 & -- \\
\hline 8 & 145. (f) & 15.0 & 9 & 1 & 2 & $\infty$ \\
\hline
\end{tabular}

(a) Niflex solution composition: $1.0 \mathrm{M} \mathrm{HNO}_{3}, 2.0 \mathrm{M} \mathrm{HF}$.

(b) Sulfex solution composition: $3 \mathrm{M} \mathrm{H}_{2} \mathrm{SO}_{4}$ in which $20 \mathrm{~g}$ per liter of Type 304 ELC stainless steel was dissolved. Solution was acrated with cylinder air at rate of $0.5 \mathrm{ml}$ of air per $\mathrm{ml}$ of solution per $\mathrm{min}$.

(c) Arranged in order of decreasing resistance to boiling Ninlex solutions.

(d) Averaged corrosion rates for duplicate, submerged, self-welded specimens over three 24-hr exposure periods.

(e) Averaged corrosion rates for duplicate, submerged, self-welded specimens over five 24-hr exposure periods.

(f) Weldments perforated by end of third exposure period. 
From the data in Table 15, it is apparent that no alloy containing a niobium addition was among the four most resistant alloys. It appears that niobium additions are undesirable for Niflex service. Apparently, copper additions do not significantly affect the Niflex resistance unless niobium is also present. In this event, increasing the copper content may lower the resistance. The presence of titanium seems desirable because of its contribution to workability, even though it does not seem to affect the corrosion rate. Certainly $9 \mathrm{w} / 0$ molybdenum is too high for this base composition and the optimum molybdenum content may lie between 3 and $6 \mathrm{w} / 0$.

The metallographic structure of the rolled, annealed alloys reveals a much higher concentration of a second phase in the alloys with poorest Niflex resistance. The highmolybdenum, niobium-containing alloys exhibit the greatest preponderance of this second phase, with Alloy 8 containing the largest amount. Titanium-containing alloys show less second phase than niobium-containing alloys, with Alloys 3 and 4 showing the least. Should either of these elements be added to improve workability and to combine with the carbon, titanium is strongly favored over niobium for Niflex service.

Apparently this second phase is responsible in large part for poor resistance of the alloys to corrosion by Niflex solutions. Weldments of self-welded Alloys 2, 8, 3, and 10 were examined by metallography. The second phase was found to a large extent in the weld structures of Alloys 2 and 8, but not to any degree in Alloys 3 and 10 . It will be recalled that the weldments of Alloys 2 and 8 were perforated by the end of three exposure periods while those of Alloys 3 and 10 showed little selective attack. Apparently, the second phase occurs in the weld structure in the same manner as in the rolled, annealed structure. It must precipitate at extremely high temperatures, and there seems to be little hope of significantly lowering the amount of second phase by heat treatments.

\section{THE SECOND SERIES OF 12 EXPERIMENTAL ALLOYS}

\section{Alloy Compositions}

Based on the knowledge gained during the fabrication, welding, and corrosion evaluations of the first series of experimental alloys, as well as on corrosion evaluations conducted on these and similar alloys at HAPO, a second series of 12 experimental alloys was prepared. The emphasis in this second group of alloys was shifted from consideration of the alloys as welding materials for vacuum-melted Hastelloy $F$ to use of the alloys themselves as container materials. The compositions selected for this second series of alloys are shown in Table 16. It will be noted that $1 \mathrm{w} / 0$ titanium was included in all of the alloys for both improved workability and carbide stabilization. Alloys 13 through 16 parallel Alloy 4, forming a group with increasing molybdenum content, copper being added to the high-molybdenum alloy. In Alloys 17 through 21, copper and molybdenum contents are varied in a $50 \mathrm{w} / 0$ nickel- $25 \mathrm{w} / 0$ chromium base.

Alloys 19 and 20 were thought to contain as much chromium, molybdenum, and nickel as possible and still maintain forgeability. Cobalt was substituted for part of the nickel in Alloys 22 through 24, while chromium and/or molybdenum were varied. This was done because of the fair-to-good corrosion behavior shown by cobalt-base alloys in several corrosive chemical solutions. 
TABLE 16. INTENDED COMPOSITIONS OF SECOND SERIES OF EXPERIMENTAL ALIOYS

\begin{tabular}{llllllll}
\hline \hline & \multicolumn{7}{c}{ Intended Composition (a), w/o } \\
\cline { 2 - 7 } Alloy & Ni & Cr & Mo & Co & Fe & Ti & Cu \\
\hline & & & & & & & \\
13 & 45 & 22 & 1.5 & -- & 29.5 & 1 & -- \\
14 & 45 & 22 & 4.5 & -- & 26.5 & 1 & -- \\
15 & 45 & 22 & 9 & $-\infty$ & 22 & 1 & $-\infty$ \\
16 & 45 & 22 & 9 & -- & 21 & 1 & 1 \\
17 & 50 & 25 & 1.5 & -- & 21.5 & 1 & $-\infty$ \\
18 & 50 & 25 & 4.5 & -- & 18.5 & 1 & -- \\
19 & 50 & 25 & 6 & $-\infty$ & 17 & 1 & -- \\
20 & 50 & 25 & 6 & -- & 16 & 1 & 1 \\
21 & 50 & 25 & 1.5 & -- & 18.5 & 1 & 3 \\
22 & 25 & 22 & 6 & 25 & 20 & 1 & $-\infty$ \\
23 & 25 & 25 & 6 & 25 & 17 & 1 & -- \\
24 & 25 & 25 & 9 & 25 & 14 & 1 & -- \\
& & & & & & & \\
\hline \hline
\end{tabular}

(a) All alloys intended to contain $0.02 \mathrm{w} / 0$ carbon, $0.6 \mathrm{w} / 0$ manganese, and $0.4 \mathrm{w} / 0$ sillcon.

\section{Melting Procedure}

Four of what appeared to be the most difficult alloys of the second series to fabricate were selected and vacuum melted first in 15-1b heats. The same procedure was used for these heats as was used for the first series of alloys. These alloys forged reasonably well, but analytical data obtained at the time indicated poor recoveries of molybdenum (57 to 71 per cent) and only one of these heats was considered useable.

In view of the apparent poor molybdenum recoveries, the final 11 heats of $12-1 b$ size were melted, using an altered procedure. Although the ingot size was the same as for the previous alloys, the hot top was reduced from about 5.8 to $2.8 \mathrm{lb}$. The melting and pouring practice employed consisted of (1) heating the major elements to $3000 \mathrm{~F}$ and holding for $10 \mathrm{~min}$, (2) lowering the temperature of the melt to $2750 \mathrm{~F}$ and making the minor element additions, and (3) pouring the melt at $2750 \mathrm{~F}$. As a result of the higher pouring temperature, the buildup of metal on the crucible wall was noticeably reduced.

The same melting stocks as were used in the first series of alloys were employed with the exception of titanium. High-purity sponge titanium was substituted for the unalloyed scrap. In addition, the cobalt included in Alloys 22 through 24 consisted of 99.5 w/o purity cobalt. Exactly the same charging procedure was used, with the cobalt being added to the nickel-chromium mixture.

The intended versus the actual composition (in parentheses) of several of the alloys is shown in Table 17. In general, the recoveries were in good agreement with the in tended composition. However, manganese recoveries were somewhat lower than anticipated. The reasons for the high carbon content of Alloy 16 and the high nitrogen content of Alloy 24 are unknown. The compositions of Alloys 23 and 24 are essentially identical. This explains the similar corrosion behavior to be discussed later. However, because of this, no corrosion results were obtained for the intended composition of Alloy 23. 
TABLE 17. CHEMICAL COMPOSITION OF SELECTED ALLOYS FROM THE SECOND SERIES

\begin{tabular}{|c|c|c|c|c|c|c|c|c|c|c|c|}
\hline \multirow[b]{2}{*}{ Alloy } & \multicolumn{11}{|c|}{ Chemical Composition (2). w/o } \\
\hline & $\mathrm{C}$ & $\mathbb{N}$ & Ni & $\mathrm{Cr}$ & Mo & $\mathrm{Co}_{0}$ & $\mathrm{Fe}$ & $\mathrm{Cu}$ & $\mathrm{Ti}$ & $\mathrm{Mn}$ & Si \\
\hline \multirow[t]{2}{*}{16} & 0.02 & $-\infty$ & 45 & 22 & 9 & - & 21 & 1 & 1 & 0.6 & 0.4 \\
\hline & $(0.07)$ & $(0.008)$ & & $(21.8)$ & $(9.6)$ & & & $(1.0)$ & $(0.97)$ & $(0.25)$ & $(0.57)$ \\
\hline \multirow[t]{2}{*}{20} & 0.02 & - & 50 & 25 & 6 & -- & 16 & 1 & 1 & 0.6 & 0.4 \\
\hline & $(<0.01)$ & $(0.074)$ & & $(24.7)$ & $(6.4)$ & & & $(0.9)$ & $(0.97)$ & $(0.27)$ & $(0.51)$ \\
\hline \multirow[t]{2}{*}{21} & 0.02 & $-\infty$ & 50 & 25 & 1.5 & $-\infty$ & 18.5 & 3 & 1 & 0.6 & 0.4 \\
\hline & $(<0.01)$ & $(0.009)$ & & $(24.7)$ & $(1.4)$ & & & $(2.6)$ & $(0.97)$ & $(0.27)$ & $(0.54)$ \\
\hline \multirow[t]{2}{*}{22} & 0.02 & $-\infty$ & 25 & 22 & 6 & 25 & 20 & - & 1 & 0.6 & 0.4 \\
\hline & $(0.006)$ & $(0.013)$ & & $(21.6)$ & $(5.4)$ & (24.1) & $(20.8)$ & & & & \\
\hline \multirow[t]{2}{*}{23} & 0.02 & $-\infty$ & 25 & 25 & 9 & 25 & 14 & -- & 1 & 0.6 & 0.4 \\
\hline & $(0.012)$ & $(0.015)$ & & $(24.6)$ & $(8.5)$ & $(23.8)$ & $(15.9)$ & & & & \\
\hline \multirow[t]{2}{*}{24} & 0.02 & - & 25 & 25 & 9 & 25 & 14 & - & 1 & 0.6 & 0.4 \\
\hline & $(0.01)$ & $(0.12)$ & & $(24.3)$ & $(8.6)$ & $(25.5)$ & & & $(0.82)$ & $(0.35)$ & $(0.54)$ \\
\hline
\end{tabular}

(a) Parentheses indicate actual analyses, all others intended values. 
Radiographic inspection of the ingots showed pipe extending $1-1 / 4$ to 2 in. into the ingot. Only the sound portions of the ingots were forged.

\section{Fabrication}

\section{Forging}

The forging temperatures given in Table 18 were determined from preliminary studies conducted on the small pilot ingots of the alloys. The main ingots of the alloys of this series were prepared for the forging operation in three different ways. Alloy 23 was heated in a Globar furnace from room temperature to the forging temperature, hot ground to improve the surface, and placed in the furnace for subsequent forging. Alloys 13, 14, 15, 16, and 21 were placed in a Globar furnace at $1600 \mathrm{~F}$, allowed to heat to $1600 \mathrm{~F}$, hot ground, and placed in a gas-fired furnace at the forging temperature. Alloys 17, 18, 19, 20, 22, and 24 were placed in a gas-fired furnace at the forging temperature, hot ground, and returned to the furnace again. All of the ingots were allowed to heat for about $1 \mathrm{hr}$ at the forging temperature before they were forged to about 3/4-in, -thick slabs and water quenched.

In general, the forging behavior of the alloys, as indicated in Table 18, was very good. However, in the case of Alloys 20 and 21, there was evidence of some hot cracks during forging at temperatures above $2100 \mathrm{~F}$; therefore, a forging temperature of $2050 \mathrm{~F}$ is recommended for these alloys. The poorest behavior was exhibited by Alloys 23 and 24, which developed moderate edge and corner cracks.

Hot Rolling

Slabs of the alloys were cut from the forged ingots and were pickled in the same solution as previously mentioned, prior to hot rolling. The rolling temperatures given in Table 18 were determined by hot rolling the forged pilot-ingot slabs first. The main ingots were rolled in one direction to $1 / 8-i n$. - thick strip and allowed to air cool after the last reduction. As indicated in Table 18, the rolling behavior of the alloys was essentially the same as their forging behavior. The temperatures used for Alloys 20 and 21 resulted in hot cracks, so a temperature of $2050 \mathrm{~F}$ is also recommended for hot rolling. Alloys 23 and 24 again demonstrated the poorest fabricability.

\section{Annealing}

On the basis of the results of the extensive annealing study performed on the first series of alloys, a solution-annealing temperature of $2050 \mathrm{~F}$ was selected for all of the alloys. The hot-rolled alloys were annealed I hr at this temperature and water quenched. Alloys 15, 16, 23, and 24 were given an additional anneal for $1 \mathrm{hr}$ at $2200 \mathrm{~F}$ and water quenched in an attempt to dissolve more of the second phase present. 
TABLE 18. FORGING AND ROLLING TEMPERATURE AND FABRICATION BEHAVIOR OF THE SECOND SERIES OF EXPERIMENTAL ALIOYS

\begin{tabular}{|c|c|c|c|c|c|c|c|c|c|c|}
\hline \multirow[b]{2}{*}{ Alloy } & \multicolumn{6}{|c|}{ Addition(a), w/o } & \multicolumn{2}{|c|}{ Forging } & \multicolumn{2}{|c|}{ Hot Rolling $(b)$} \\
\hline & $\mathrm{Ni}$ & $\mathrm{Cr}_{1}$ & Mo & $\mathrm{Co}$ & $\mathrm{Cu}$ & Fe & Temperature, $F$ & Formability & Temperature, & Formability \\
\hline 13 & 45 & 22 & 1.5 & $-\infty$ & $-\infty$ & 29.5 & 2125 & Very good & 2150 & Very good \\
\hline 14 & 45 & 22 & 4.5 & $-\infty$ & - & 26.5 & 2125 & Very good & 2150 & Very good \\
\hline 15 & 45 & 22 & 9 & $-\infty$ & $-\infty$ & 22 & 2125 & Very good & 2150 & Very good \\
\hline 16 & 45 & 22 & 9 & $-\infty$ & 1 & 21 & 2125 & Very good & 2100 & Vexy good \\
\hline 17 & 50 & 25 & 1.5 & $-\infty$ & $-\infty$ & 21.5 & 2175 & Very good & 2150 & Very good \\
\hline 18 & 50 & 25 & 4.5 & $-\infty$ & $-\infty$ & 18.5 & 2175 & Very good & 2200 & Vexy good \\
\hline 19 & 50 & 25 & 6 & $-\infty$ & $-\infty$ & 17 & 2175 & Very good & 2200 & Very good \\
\hline 20 & 50 & 25 & 6 & $-\infty$ & 1 & 16 & 2175 & Good & 2100 & Good \\
\hline 21 & 50 & 25 & 1.5 & $-\infty$ & 3 & 18.5 & 2125 & Good & 2100 & Good \\
\hline 22 & 25 & 22 & 6 & 25 & $-\infty$ & 20 & 2175 & Very good & 2150 & Very good \\
\hline 23 & 25 & 25 & 9 & 25 & $-\infty$ & 14 & 2200 & Faix & 2200 & Fair \\
\hline 24 & 25 & 25 & 9 & 25 & $-\infty$ & 14 & 2175 & Fair & 2200 & Eair \\
\hline
\end{tabular}

(a) Base alloy contained $1 \mathrm{w} / 0$ titanium, $0.6 \mathrm{w} / 0$ manganese, $0.4 \mathrm{w} / 0$ silicon, and $0.02 \mathrm{w} / 0$ carbon. Addituons shown are intended values.

(b) Alloys reheated to rolling temperature after each roll pass. 
Hardness data for the solution-annealed alloys are given in Table 19. General observations that can be made are (1) increasing molybdenum from 1.5 to 9 w/o resulted in increased hardness, (2) substituting $25 \mathrm{w} / 0$ cobalt for the same amount of nickel increased the hardness, and (3) adding copper apparently did not affect the hardness. Densities of these alloys as measured in the hot-rolled, annealed condition by water displacement for corrosion purposes are also shown in Table 19.

\section{Metallographic Examination}

Metallographic examination of the jolution-annealed materials showed a generally fine-grained structure and randomly dispersed minor phases. In general, the amount of undissolved minor phases was slight, with the exception of Alloys 23 and 24, in which a large amount of undissolved minor phase occurred. The microstructures of two of the alloys of the second series and of vacuum-melted Hastelloy F Heat FV 123 are shown in Figure 17. The same metallographic procedure was used as described previously for the first series of alloys. The microstructure of Alloy 20 is typical for the alloys (13, 14, $17,18,19,21$, and 22) containing small amounts of undissolved minor phases, and that of Alloy 24 is also representative of Alloy 23. Alloys 15 and 16 contained more precipitated phase than that shown for Alloy 20, but much less than that for Alloy 24.

\section{Allocation of Strip and Description of Welding Procedure}

As with the first series, pieces weighing approximately 1 lb each of Alloys 13 through $2+1$ were shipped to HAPO for corrosion evaluations at that site. Since only the self-welded materials were of interest, only this type of corrosion specimen was made at BMI from the second series of experimental alloys.

Welding was carried out in much the same manner as for the first series. Pieces $1-1 / 4$ by 7 in., cut side by side (where possible) from the annealed strip, were grit blasted, ground for a V-joint of about a 70-deg included angle, pickled, and butt welded together. The filler metals were sheared strips of the basis alloys cleaned in the same manner. An argon flow rate of $10 \mathrm{ft}^{3}$ per hr was used in the backup, and $14 \mathrm{ft}^{3}$ per $\mathrm{hr}$ was used through the torch. A current of $60 \mathrm{amp}$ at between 12 and $15 \mathrm{v}$ was used.

Radiographic and metallographic examinations showed the weldments to be sound and uncontaminated. All of the alloys welded in a satisfactory manner. The weldments of the cobalt-containing compositions, Alloys 22 through 24, were coated with purpleviolet films. These were no longer visible when corrosion specimens were machined from the welded strips. 
TABLE 19. HARDNESS OF EXPERIMENTAL ALLOYS OF THE SECOND SERIES SOLUTION ANNEALED I HR AND WATER QUENCHED

\begin{tabular}{|c|c|c|c|c|c|c|c|c|c|}
\hline \multirow[b]{2}{*}{ Alloy } & \multicolumn{6}{|c|}{ Nominal Composition(a), w/o } & \multirow{2}{*}{$\begin{array}{c}\text { Annealing } \\
\text { Temperature, }\end{array}$} & \multirow{2}{*}{$\begin{array}{c}\text { Rockwell B } \\
\text { Hardness }\end{array}$} & \multirow{2}{*}{$\begin{array}{l}\text { Density (b) } \\
\text { g per } \mathrm{cm}^{3} \\
\end{array}$} \\
\hline & $\mathrm{Ni}$ & Cr & Mo & $\mathrm{CO}$ & $\mathrm{Cu}$ & $\mathbb{E e}$ & & & \\
\hline 13 & 45 & 22 & 1.5 & -- & -- & 29.5 & 2050 & 68.0 & 8.08 \\
\hline 14 & 45 & 22 & 4.5 & -- & -- & 26.5 & 2050 & 77.5 & 8.12 \\
\hline 15 & 45 & 22 & 9 & - & $-\infty$ & 22 & $2200(c)$ & 83.5 & 8.20 \\
\hline 16 & 45 & 22 & 9 & -- & 1 & 21 & $2200(c)$ & 83.5 & 8.20 \\
\hline 17 & 50 & 25 & 1.5 & -- & -- & 21.5 & 2050 & 72.5 & 8.07 \\
\hline 18 & 50 & 25 & 4.5 & $-\infty$ & -- & 18.5 & 2050 & 77.0 & 8.12 \\
\hline 19 & 50 & 25 & 6 & $-\infty$ & $-\infty$ & 17 & 2050 & 82.0 & 8.12 \\
\hline 20 & 50 & 25 & 6 & $-\infty$ & 1 & 16 & 2050 & 79.5 & 8.16 \\
\hline 21 & 50 & 25 & 1.5 & -- & 3 & 18.5 & 2050 & 72.0 & 8.09 \\
\hline 22 & 25 & 22 & 6 & 25 & -- & 20 & 2050 & 82.0 & 8.30 \\
\hline 23 & 25 & 25 & 9 & 25 & -- & 14 & $2200(c)$ & 98.5 & 8.24 \\
\hline 24 & 25 & 25 & 9 & 25 & -- & 14 & $2200(\mathrm{c})$ & 96.0 & 8.26 \\
\hline
\end{tabular}

(a) Base alloy contains $1 \mathrm{w} / 0$ titanium, $0.6 \mathrm{w} / 0$ manganese, $0.4 \mathrm{w} / \mathrm{o}$ silicon, and $0.02 \mathrm{w} / 0$ carbon.

(b) Deternined by the water-displacement method.

(c) Annealed $1 \mathrm{hr}$ at $2050 \mathrm{~F}$ plus $1 \mathrm{hs}$ at $2200 \mathrm{~F}$. 

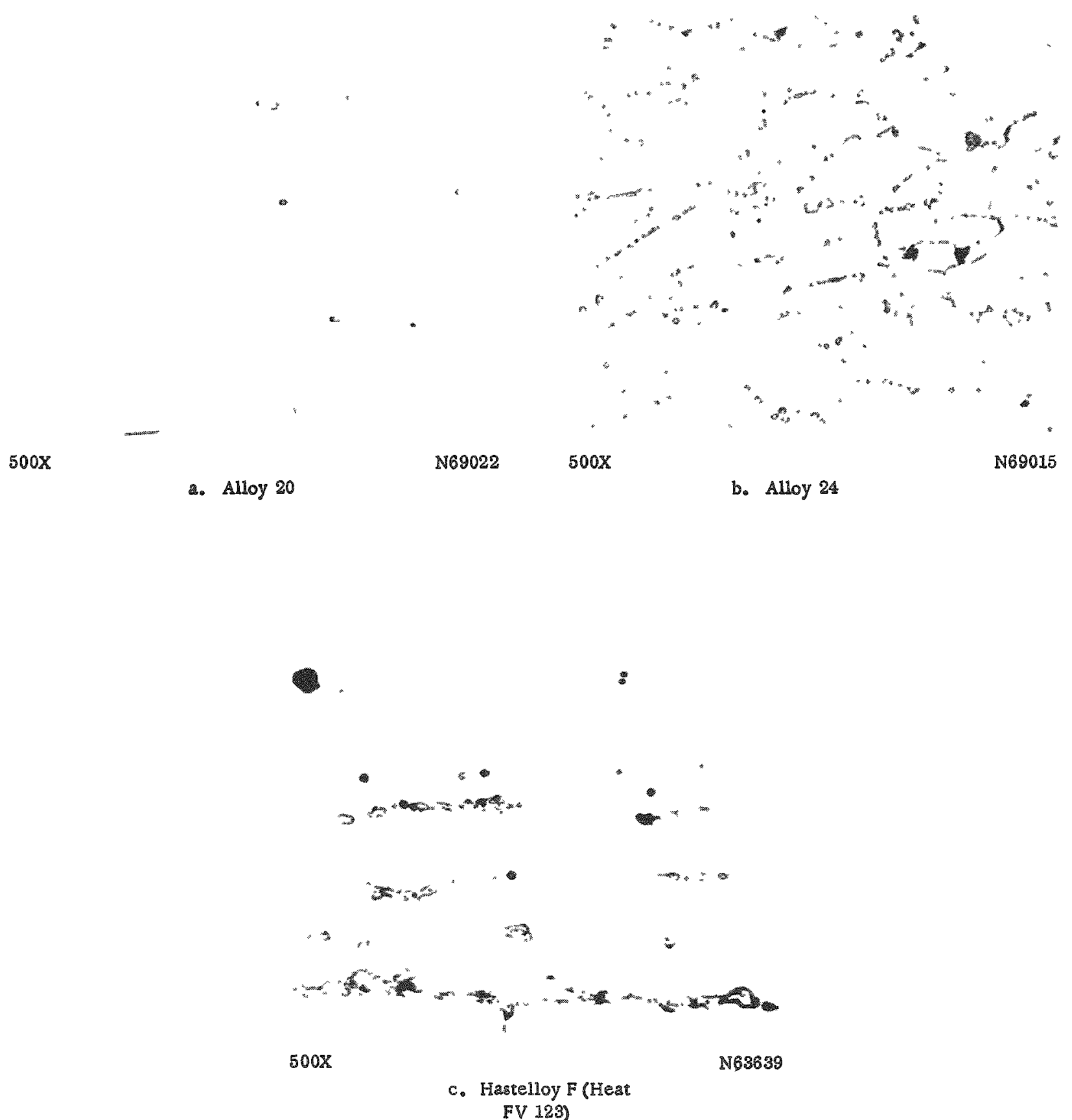

FIGURE 1\%. MICROSTRUCTURES OF TWO SOLUTION-ANNE ALED EXPERIMENTAL NICKEL-BASE ALLOYS OF THE SECOND SERES AND OF HASTELLOY F 
Corrosion Studies of Self-Welded Specimens

Sulfex Studies

The Sulfex studies were conducted with aerated solutions in the same manner as used for the self welded specimens of the first series. The corrosion rates are given in Table 20, the averaged rates for submerged specimens are shown in Figure 18 , and the after-exposure appearance of representative submerged specimens is shown in Figure 19. During the third 24-hour exposure period the aeration was accidently stopped for $15 \mathrm{hr}$. Consequently, the rates for most specinens during this period were somewhat lower than during the other periods.

Both of the submerged specimens of Alloy 13 had abnormally high corrosion rates during the first exposure period, as did one submerged specimen of Alloy 17. For the remainder of the periods the rates for these specimens fell within the normal range. This may indicate that borderline conditions of normal and extreme corrosion exist for these alloys even in the aerated Sulfex solutions. Both of these alloys contained only $1.5 \mathrm{w} / 0 \mathrm{molybdenum}$ with no copper. Aside from these two alloys, none of the other alloys was selectively attacked at the weldments or in heat-affected zones.

With the exception of Alloys 23 and 24, the remaining alloys could all be grouped in the range of 9 to 17 mils per month. While these rates are slightly lower than those of the first group upon similar exposure, the difference is not great and may be accounted for, in part, by the lack of aeration during the third exposure period. All of the submerged specimens were actively corroding during each period while the attack by the vapor phase was, for the most part, negligible.

Alloys 23 and 24 showed exceptional resistance to the aerated boiling Sulfex solution. All of the specimens were rotated into different flask and condenser systems upon each period of exposure, so this is not a case of lack of aeration. Alloy 22 with 3 w/o less chromium and a much lower molybdenum content did not show this exceptional resistance.

Cross sections of submerged specimens of Alloys 19, 20, and 21 showing the absence of selective attack are presented in Figure 20.

\section{Niflex Studies}

The results of the Nifler corrosion studies, conducted in the same manner as used for the first series of alloys are given in Table 21. The corrosion rates and appear ance of individual specimens are shown in Figures 21 and 22.

It can be seen from Table 21 that all of the alloys had high corrosion rates in the Niflex solutions. However, in the case of Alloys 18, 19, and 20, the rates were significantly lower than those obtained with the first series. In all but a few isolated instances, the rates for the submerged specimens were greater than those for the corresponding specimens exposed to the vapor phase. However, the corrosion totes in the vapor were substantial. 
TABLE 20. CORROSION RATES OF SELF-WELDED SPECIMENS OF THE SECOND SERIES OF EXPERIMENTAL ALLOYS UPON EXPOSURE TO AERA TED, BOILING SULFEX SOLUTION(a)

\begin{tabular}{|c|c|c|c|c|c|c|c|c|c|c|c|c|}
\hline \multirow{4}{*}{$\begin{array}{l}\begin{array}{c}\text { Alloy and } \\
\text { Filler }\end{array} \\
\frac{13}{13}\end{array}$} & \multirow{4}{*}{$\begin{array}{l}\text { Specimen } \\
\text { Position }\end{array}$} & \multicolumn{10}{|c|}{ Corrosion Rate Each 24-Hr Period, mils per month } & \multirow{4}{*}{$\begin{array}{c}\begin{array}{c}\text { Liquid } \\
\text { Average } \\
68.3\end{array} \\
\end{array}$} \\
\hline & & \multicolumn{2}{|c|}{ First } & \multicolumn{2}{|c|}{ Second } & \multicolumn{2}{|c|}{ Third $^{(b)}$} & \multicolumn{2}{|c|}{ Fourth } & \multicolumn{2}{|c|}{ Fifth } & \\
\hline & & 3.4 & 3.0 & 1.2 & 1.4 & 0.7 & 0.6 & 0.8 & 0.8 & 1.4 & 0.2 & \\
\hline & & 287. & 289. & 20. & 18. & 11. & 12. & 10. & 12. & 12. & 12. & \\
\hline \multirow[t]{2}{*}{14} & Vapor & 03 & 1.4 & 0.5 & 0.1 & 0.4 & 0.4 & 0.5 & 0.6 & 0.7 & 0.8 & \\
\hline & Liquid & 17. & 14. & 6.7 & 6.8 & 9.8 & 9.6 & 15. & 14. & 8.8 & 9.0 & 11.1 \\
\hline \multirow[t]{2}{*}{15} & Vapor & 0.1 & 0.1 & 0.0 & 0.0 & 0.0 & 0.5 & 0.4 & 0.0 & 0.0 & 0.1 & \\
\hline & Liquid & 23. & 22 & 21. & 10. & 6.9 & 6.3 & 14. & 14 & 21. & 20 & 16.7 \\
\hline \multirow[t]{2}{*}{16} & Vapor & 0.1 & 0.1 & 0.0 & 0.2 & 0.3 & 0.3 & 0.1 & 0.1 & 0.0 & 0.0 & \\
\hline & Liquid & 19. & 18. & 13. & 12. & 9.7 & 11. & 21. & 21. & 18. & 17. & 16.0 \\
\hline \multirow[t]{2}{*}{17} & Vapor & 3.6 & 3.0 & 0.3 & 0.4 & 0.5 & 0.8 & 0.7 & 0.6 & 0.0 & 0.0 & \\
\hline & Liquid & 360 & 39. & 11. & 3.8 & 9.3 & 4.1 & 8.0 & 4.1 & 21. & 11. & 47.1 \\
\hline \multirow[t]{2}{*}{18} & Vapor & 0.4 & 0.7 & 0.0 & $g(c)$ & 0.1 & 0.4 & 0.0 & 0.0 & $\mathrm{~g}$ & 0.0 & \\
\hline & Liquid & 23. & 22 & 10. & 11. & 6.5 & 6.5 & 21. & 21. & 15. & 15. & 15.1 \\
\hline \multirow[t]{2}{*}{19} & Vapor & 0.1 & 0.2 & 1.0 & 0.9 & 0.4 & 0.6 & 1.9 & 1.9 & 0.5 & 0.6 & \\
\hline & Liquid & 14 & 14 & 11. & 11. & 6.0 & 5.9 & 7.5 & 7.4 & 8.8 & 8.0 & 9.36 \\
\hline \multirow[t]{2}{*}{20} & Vapor & 0.2 & 0.2 & 0.0 & 0.0 & 0.2 & 0.3 & 0.0 & 0.0 & 0.0 & 0.0 & \\
\hline & Liquid & 21. & 21. & 12 & 12. & 8.6 & 8.8 & 12. & 12. & 12 & 12 & 13.1 \\
\hline \multirow[t]{2}{*}{21} & Vapor & 0.2 & 0.2 & 0.0 & 0.0 & 0.5 & 0.6 & 0.4 & 0.4 & 0.3 & 0.3 & \\
\hline & Liquid & 15 & 14. & 10 & 10 & 8.4 & 7.9 & 12. & 11. & 8.5 & 8.5 & 10.5 \\
\hline \multirow[t]{2}{*}{22} & Vapor & 0.1 & 0.1 & 0.4 & 0.3 & 0.3 & 0.3 & 0.0 & 0.5 & $g$ & 0.4 & \\
\hline & Liquid & 23. & 22. & 7.6 & 7.8 & 7.7 & 8.4 & 9.1 & 10. & 10. & 10. & 11.6 \\
\hline \multirow[t]{2}{*}{23} & Vapor & 0.0 & 0.1 & 0.0 & 0.0 & 1.0 & 0.0 & 0.0 & 0.0 & 0.0 & 0.0 & \\
\hline & Liquid & 0.4 & 0.4 & 0.4 & 0.4 & 0.2 & 0.2 & 0.2 & 0.2 & 0.2 & 0.2 & 0.28 \\
\hline \multirow[t]{2}{*}{24} & Vapor & 0.1 & 0.0 & 0.2 & 0.1 & 0.7 & 0.2 & 0.3 & 0.1 & 0.0 & 0.0 & \\
\hline & Liquid & 0.4 & 0.4 & 0.4 & 0.4 & 0.3 & 0.2 & 0.0 & 0.2 & 0.2 & 0.1 & 0.26 \\
\hline Hastelloy & Vapor & 0.5 & 0.4 & 0.1 & 0.1 & 0.7 & 0.8 & 0.4 & 0.5 & 0.0 & 0.0 & \\
\hline $\begin{array}{l}\text { F } \\
\text { (unwelded) }\end{array}$ & Liquid & 7.4 & 7.7 & 17. & 14. & 8.5 & 8.5 & 15. & 15 & 15. & 14. & 12.2 \\
\hline
\end{tabular}

(a) Solution composition: $3.5 \mathrm{M} \mathrm{H}_{2} \mathrm{SO}_{4}$ in which $20 \mathrm{~g}$ per liter of Type 304 ELC stainless steel was dissolved. Solutions were aerated with cylinder air at the rate of $0.5 \mathrm{ml}$ of ais per $\mathrm{ml}$ of solution per min.

(b) Aeration was accidently stopped during this period. Aeration proceeded for only 9 hr.

(c) g indicates a small gain in weight. 


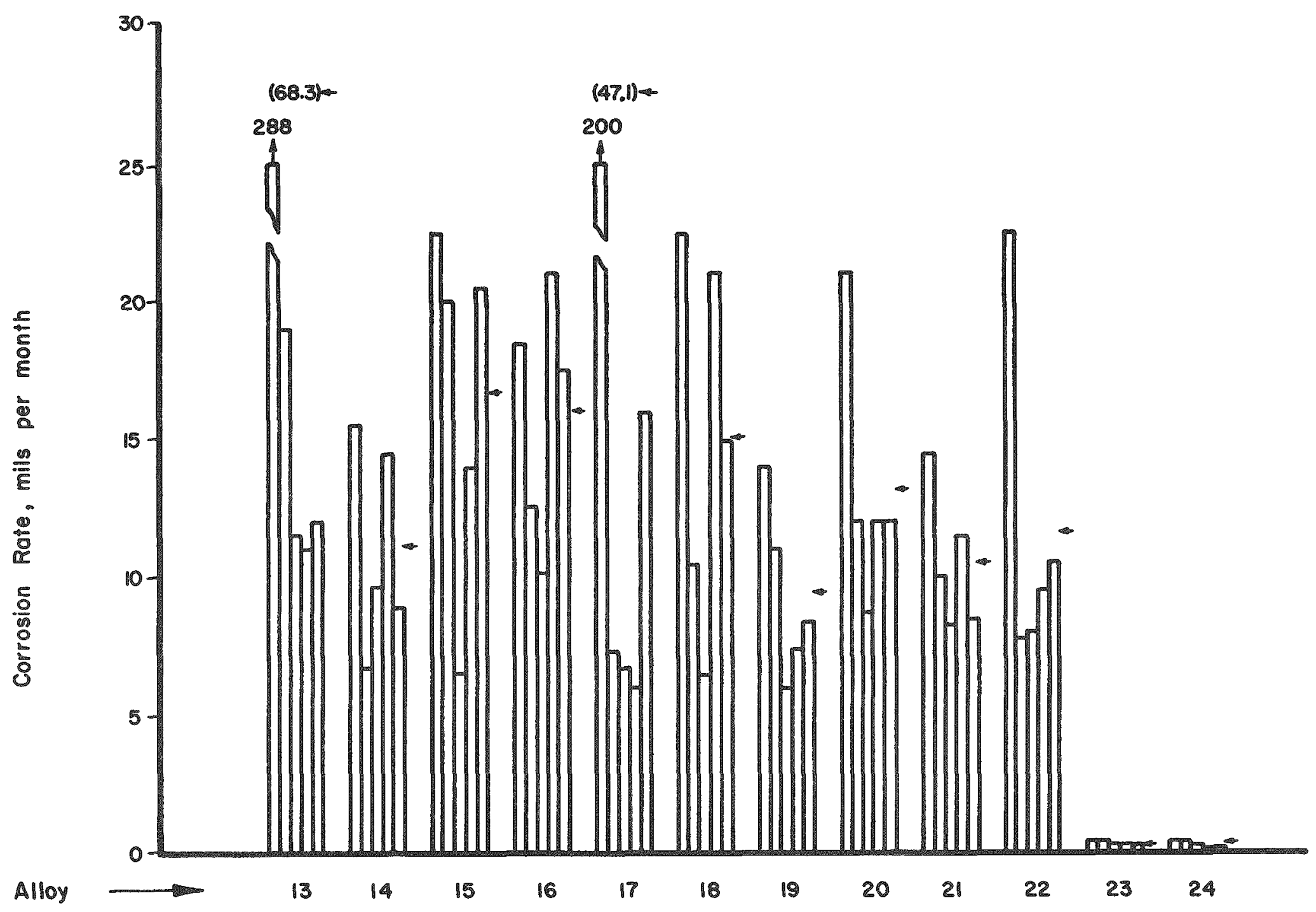

FIGURE 18. CORROSION OF SELF-WELDED SECOND SERIES OF EXPERIMENTAL ALLOYS UPON EXPOSURE TO SULFEX SOLUTION

Specimens were submerged in aerated boiling solutions. Average rates for duplicate specimens for each 24-hr period are shown. Arrow indicates over-all average. Aeration occurred during only 9 hr of the third 24-hr period. 

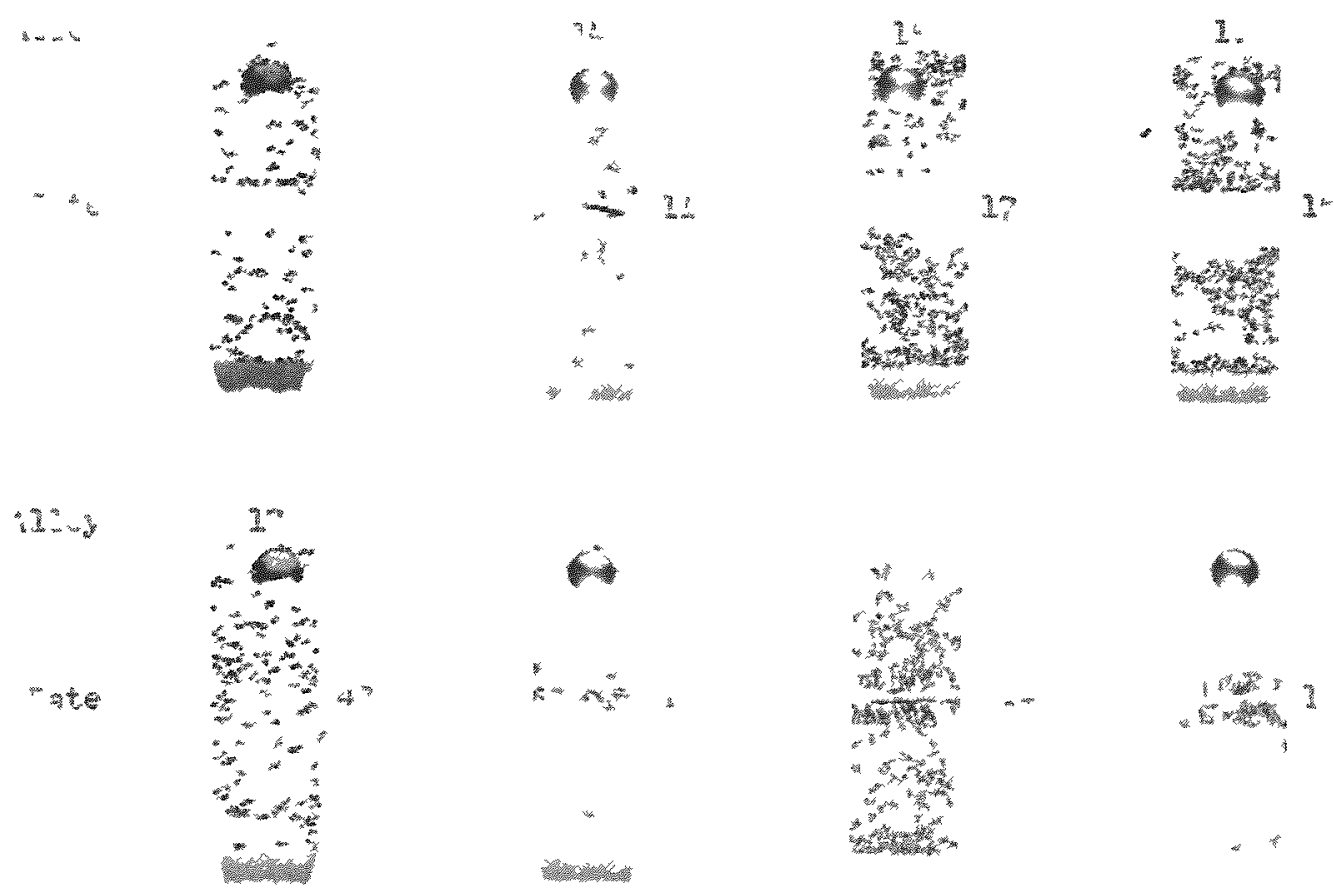

A12oy

$$
\text { s. }
$$

\section{-}
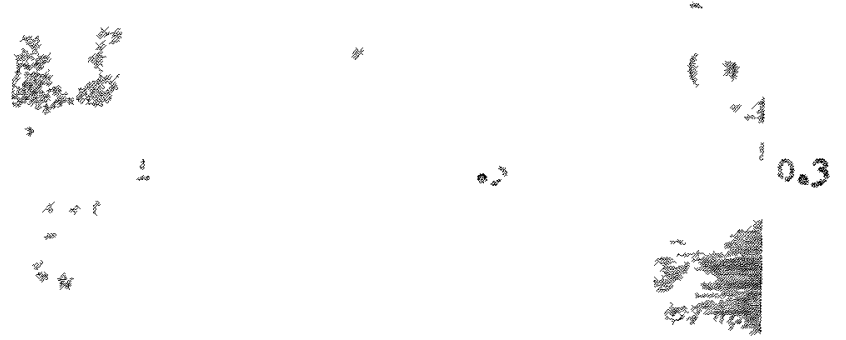

FIGURE 19. SELF-WELDED SPECIMENS OF THE SECOND SERIES OF EXPERMENTAL ALLOYS AFTER EXPOSURE TO SULFEX SOLUTION

Specimens were submerged in aerated $(0.5 \mathrm{ml}$ of ar per $\mathrm{ml}$ of solution per min) boilung solutions. Corrosion rates, given in mils per month, are average values for duplicate specimens exposed over five 24 -hr penods 


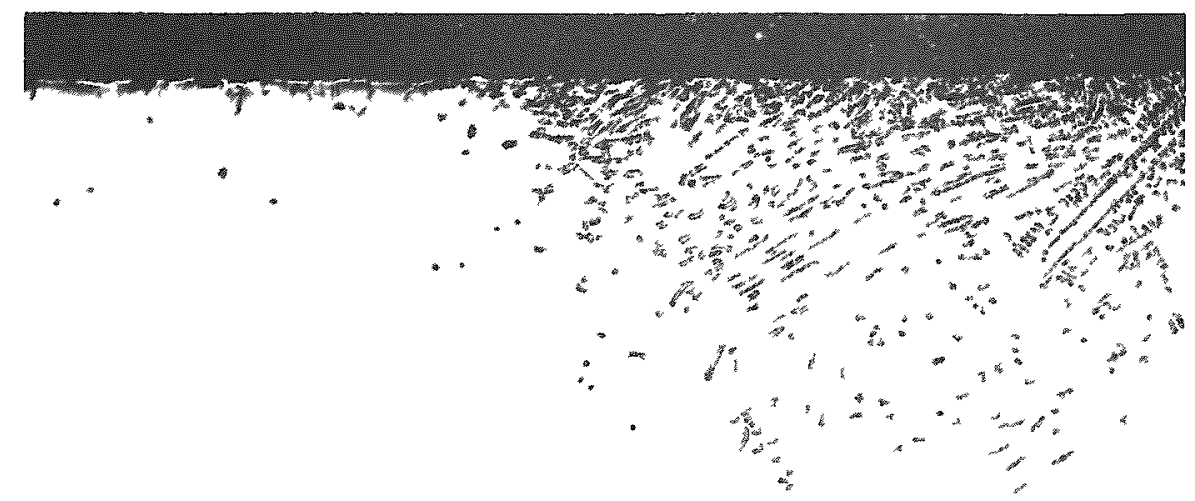

70X 2. Alloy $19 \quad$ C1110

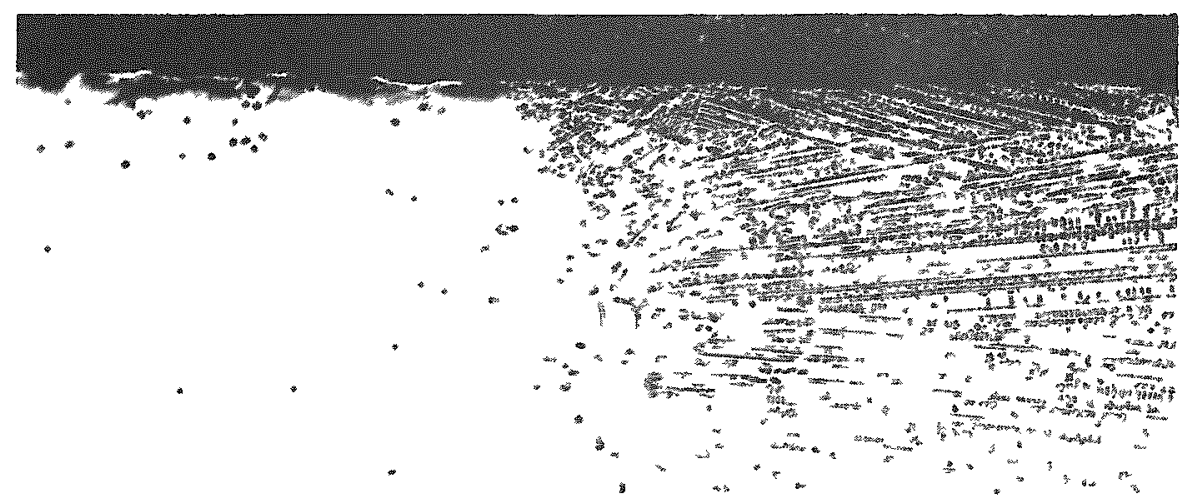

$70 x$

b. Alloy 20

C1109

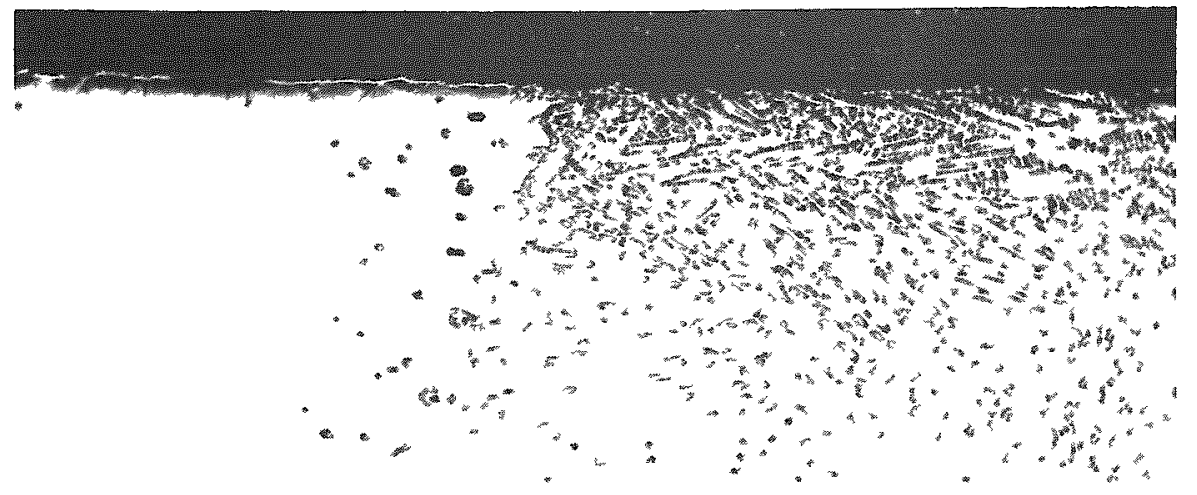

$70 \times$

c. Alloy 21

C1108

TIGURE 20. CROSS SECTIONS OF SUBMERGED, SELF-WELDED SFECIMENS SHOWING WELDMENT AND BASIS METAL AFTER EXPOSURE TO SULFEX SOLUTION

None of these three alloys was selecuvely attacked. 
TABLE 21. CORROSION RATES OF SELF-WELDED SPECIMENS OF THE SECOND SERIES OF EXPERIMENTAL ALLOYS UPON EXPOSURE TO BOILING NIFLEX SOLUTION ${ }^{(a)}$

\begin{tabular}{|c|c|c|c|c|c|c|c|c|c|c|c|c|}
\hline \multirow{4}{*}{$\begin{array}{l}\begin{array}{l}\text { Alloy and } \\
\text { Filler }\end{array} \\
13\end{array}$} & \multirow{3}{*}{$\begin{array}{l}\begin{array}{c}\text { Specimen } \\
\text { Position }\end{array} \\
\text { Vapor }\end{array}$} & \multicolumn{11}{|c|}{ Corrosion Rate Each $24-\mathrm{Hr}$ Period, mils per month } \\
\hline & & \multicolumn{2}{|c|}{ First } & \multicolumn{2}{|c|}{ Second } & \multicolumn{2}{|c|}{ Third } & \multicolumn{2}{|c|}{ Fourth } & \multicolumn{2}{|c|}{ Fifth } & \multirow[t]{2}{*}{$\begin{array}{l}\text { Liquid } \\
\text { Average }\end{array}$} \\
\hline & & 61 & 160 & 161 & 117 & 126 & 58 & 96 & 99 & 148 & 98 & \\
\hline & Líquid & 133 & 102 & 108 & 117 & 123 & 127 & 125 & 120 & 108 & 118 & 118.1 \\
\hline \multirow[t]{2}{*}{14} & Vapor & 33 & 34 & 35 & 39 & 31 & 69 & 37 & 53 & 19 & 28 & \\
\hline & Liquid & 61 & 63 & 59 & 59 & 60 & 56 & 58 & 56 & 38 & 55 & 56.5 \\
\hline \multirow[t]{2}{*}{15} & Vapor & 30 & 27 & 34 & 36 & 36 & 29 & 34 & 27 & 27 & 30 & \\
\hline & Liquid & 32 & 31 & 33 & 33 & 34 & 35 & 34 & 34 & 34 & 34 & 33.4 \\
\hline \multirow[t]{2}{*}{16} & Vapor & 32 & 29 & 34 & 32 & 46 & 43 & 42 & 30 & 38 & 37 & \\
\hline & Liquid & 32 & 32 & 35 & 35 & 35 & 38 & 38 & 36 & 37 & 36 & 35.4 \\
\hline \multirow[t]{2}{*}{17} & Vapor & 27 & 68 & 84 & 73 & 76 & 74 & 20 & 24 & 49 & 35 & \\
\hline & Liquid & 63 & 45 & 47 & 49 & 55 & 50 & 49 & 54 & 50 & 53 & 51.5 \\
\hline \multirow[t]{2}{*}{18} & Vapor & 29 & 23 & 23 & 27 & 72 & 37 & 47 & 32 & 18 & 51 & \\
\hline & Liquid & 30 & 33 & 31 & 30 & 27 & 27 & 30 & 30 & 30 & 27 & 29.5 \\
\hline \multirow[t]{2}{*}{$1 \%$} & Vapor & 21 & 20 & 30 & 29 & 20 & 21 & 31 & 19 & 20 & 33 & \\
\hline & Liquid & 26 & 26 & 24 & 27 & 27 & 24 & 27 & 26 & 27 & 22 & 25.0 \\
\hline \multirow[t]{2}{*}{20} & Vapor & 15 & 38 & 19 & 25 & 17 & 17 & 19 & 15 & 25 & 18 & \\
\hline & Liquid & 23 & 23 & 23 & 22 & 21 & 18 & 23 & 26 & 22 & 22 & 22.3 \\
\hline \multirow[t]{2}{*}{21} & Vapor & 18 & 21 & 16 & 26 & 22 & 22 & 28 & 20 & 27 & 23 & \\
\hline & Liquid & 47 & 48 & 37 & 36 & 33 & 37 & 35 & 33 & 43 & 35 & 38.4 \\
\hline \multirow[t]{2}{*}{22} & Vapor & 30 & 50 & 41 & 38 & 56 & 45 & 55 & 48 & 33 & 23 & \\
\hline & Liquid & 62 & 62 & 60 & 61 & 60 & 63 & 58 & 58 & 57 & 55 & 59.6 \\
\hline \multirow[t]{2}{*}{23} & Vapor & 21 & 22 & 32 & 25 & 33 & 31 & 40 & 29 & 34 & 34 & \\
\hline & Liquid & 34 & 34 & 59 & 56 & 63 & 64 & 62 & 63 & 60 & 61 & 55.6 \\
\hline \multirow[t]{2}{*}{24} & Vapor & 22 & 19 & 32 & 42 & 38 & 27 & 35 & 45 & 30 & 52 & \\
\hline & Liquid & 34 & 36 & 54 & 59 & 58 & 65 & 58 & 59 & 55 & 53 & 53.1 \\
\hline Mastelloy & Vapor & 34 & 34 & 51 & 49 & 64 & 64 & 71 & 54 & 86 & 38 & \\
\hline $\begin{array}{c}F \\
\text { (unwelded) }\end{array}$ & Liquid & 40 & 40 & 47 & 48 & 69 & 71 & 101 & 99 & 121 & 124 & 76.0 \\
\hline
\end{tabular}

(a) Solution composition: $1.0 \mathrm{MHNO}_{3}, 2.0 \mathrm{M} \mathrm{HF}$. 


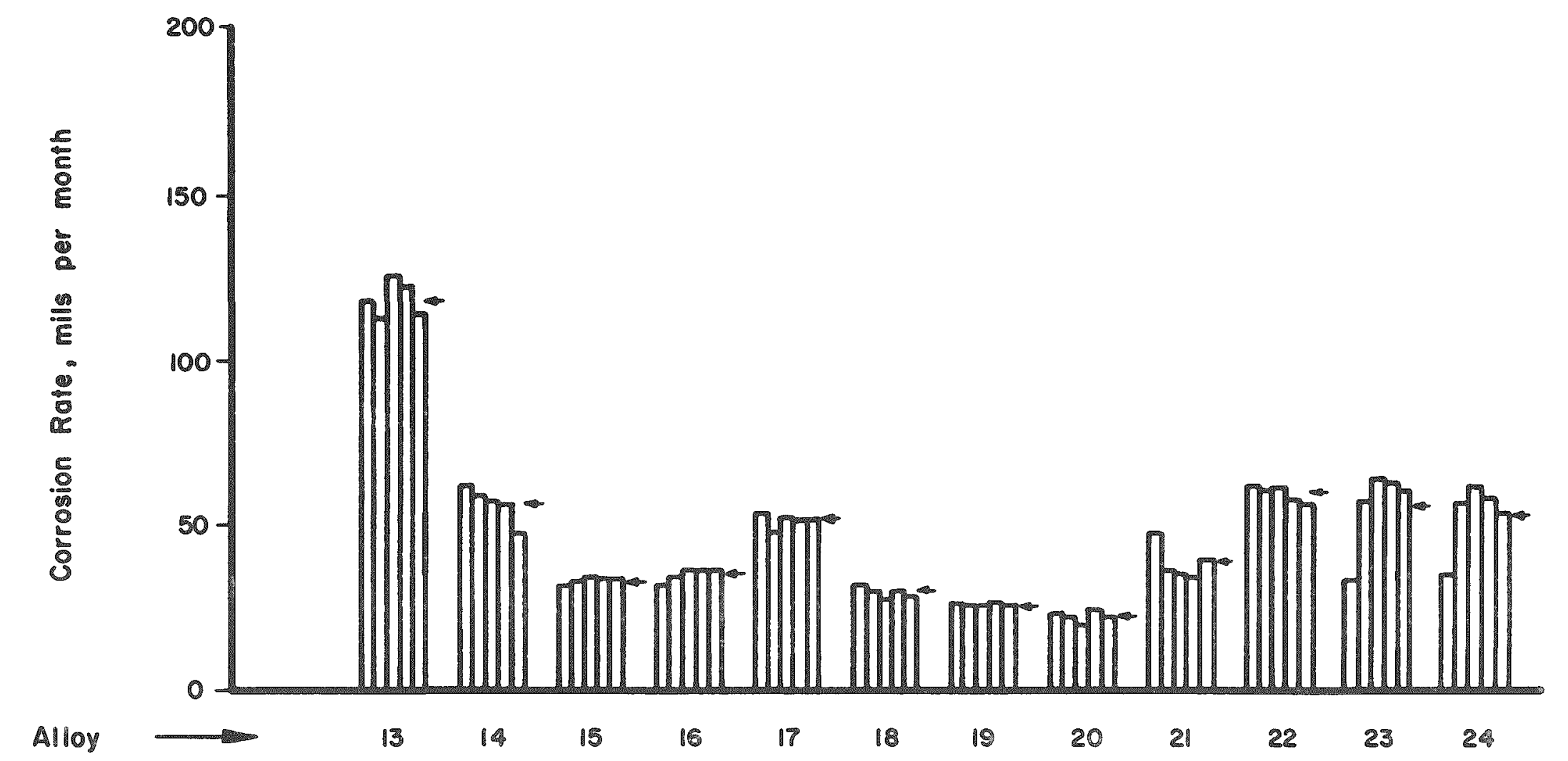

FIGURE 21. CORROSION OF SELF-WELDED SECOND SERIES OF EXPERIMENTAL ALLOYS UPON EXPOSURE TO NIF LEX SOLUTION

Specimens were submerged in nonaerated boiling solutions. Average rates for duplicate specimens for each 24-hr period are shown. Arrows indicate over-all average. 


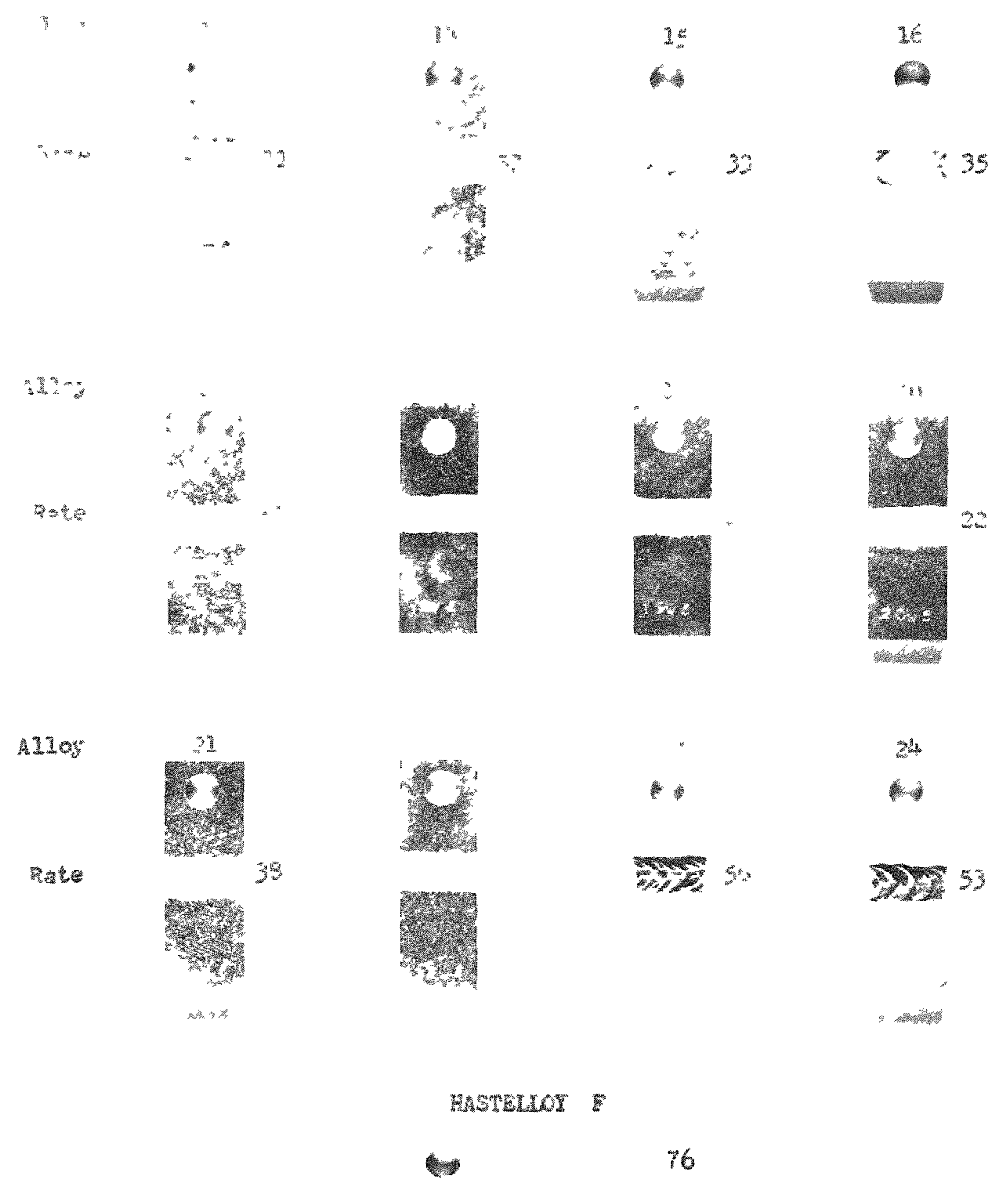

N70030

FIGURE 22. SELF-WELDED SPECIMENS OF THE SECOND SERIES OF EXPERIMENTAL ALLOYS AFTER EXPOSURE TO NIFLEX SOLUTION

Specimens were submerged in nonaerated bolling solutions. Corrosion rates, given in mils per month, are average values for duplicate specimens exposed over five 24-hr periods. 
It is evident from Figure 22 that the weldments of Allovs 23 and 24 - the two alloys that performed so well in Sulfex solutions - were severely attacked by the Niflex exposure. In fact, these weldments were penetrated by the end of five exposure periods.

While there was no evidence of selective attack in the heat-affected areas of the basis metals, except for a slight indication on Alloys 15, 16, 23, and 24, most of the weldments were preferentially attacked. The only alloys of the second series which did not appear to be selectively attacked at the weldments were Alloys 18, 19, and 20. Cross sections of the submerged specimens of Alloys 19 and 20, which showed practically no selective attack, and of Alloy 21, which was selectively attacked to a slight extent, but which was also chosen for one of the larger heats as will be mentioned, are shown in Figure 23.

\section{CONCLUSIONS AND RECOMMENDATIONS BASED ON THE} TWO SERIES OF EXPERIMENTAI ALLOYS

As previously indicated, the research was initially directed toward developing a welding alloy for use with vacuum-melted Hastelloy $F$. However, as the program progressed, it became evident that development of a corrosion-resistant welding alloy would not insure satisfactory performance life of Hastelloy $F$ vessels, since this material was highly susceptible to severe intergranular penetration in the heat-affected zones adjacent to the weldment. On the other hand, the data suggested that several of the original experimental compositions exhibited corrosion and welding properties which were superior to those of existing container materials. In view of this, a major effort was then directed toward finding new weldable container materials. In subsequent research, several alloy compositions were developed which seem to exhibit no tendency toward selective attack, either in the weldments or in the heat-affected zones, and to have significantly better general resistance to Niflex decladding solutions than vacuum-melted Hastelloy $F$.

In a program limited to 24 experimental alloys, complete assurance that the optimum alloy has been created cannot be expected to emerge. However, sufficient experimental results have been gathered to give strong indications of preferred alloy compositions.

For example, it seems clear that niobium additions lower the resistance of the nickel-base alloys to selective attack by Niflex solutions. Similar results also were found for cobalt additions of the order of $25 \mathrm{w} / \mathrm{O}$.

The most promising alloy compositions are those of the $45 \mathrm{w} / 0$ nickel- $22 \mathrm{w} / 0$ chromium- $1 \mathrm{w} / 0$ titanium group and the $50 \mathrm{w} / 0$ nickel- $25 \mathrm{w} / 0$ chromium-1 w/o titanium group with varying amounts of copper and molybdenum.

The compositional variables, together with the corrosion rates, for these two groups are shown in Table 22 and are plotted in Figures 24 and 25 . The curves indicate that about $6 \mathrm{w} / 0$ molybdenum is necessary for maximum resistance. Copper additions significantly improved the resistance of these alloys when the molybdenum content was less than $6 \mathrm{w} / 0$ but had little effect at higher concentrations. Increasing the nickel from 45 to $50 \mathrm{w} / 0$ and the chromium from 21 to $25 \mathrm{w} / 0$ also significantly improved the 

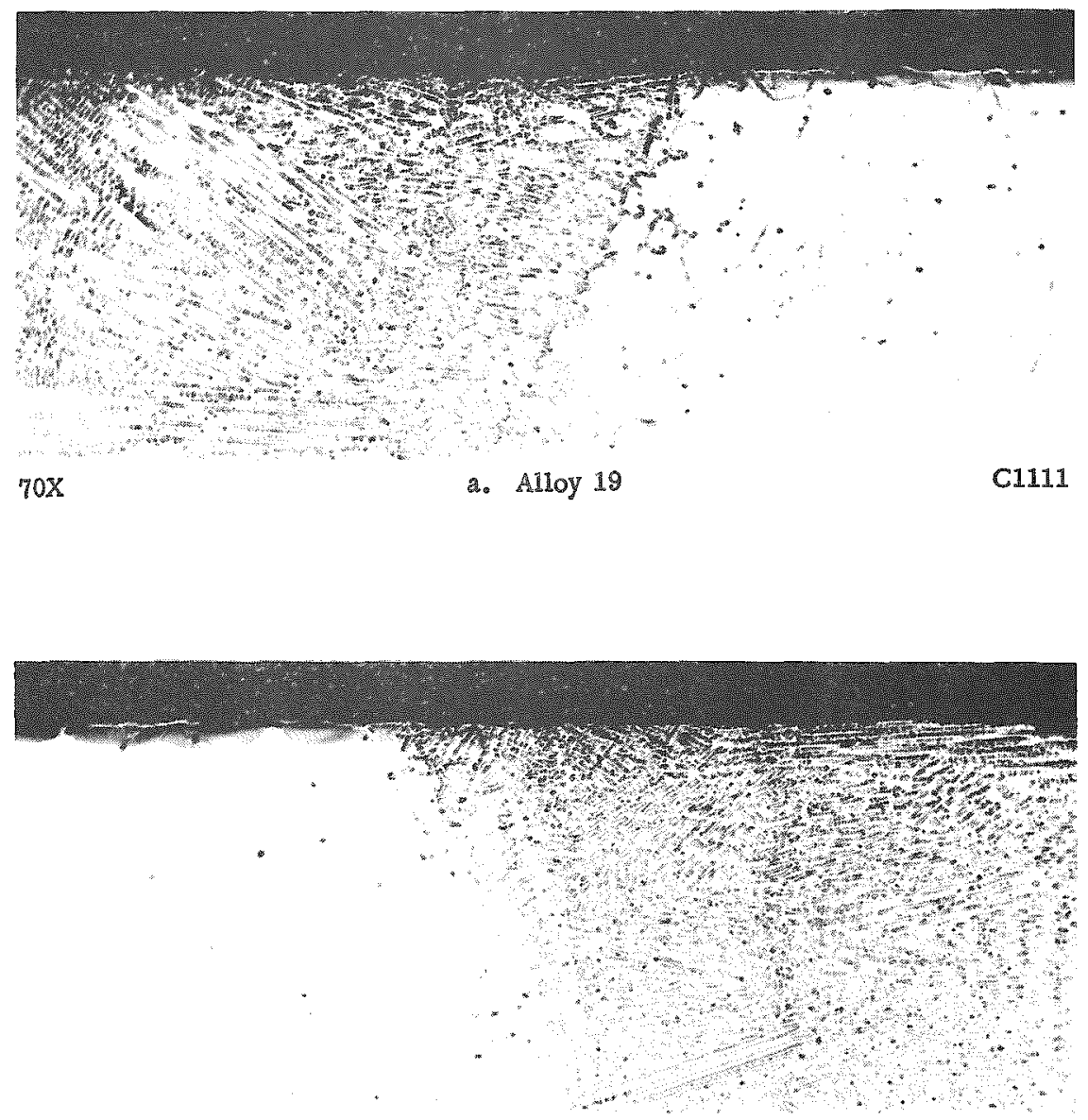

$70 X$

b. Aloy 20

C1112

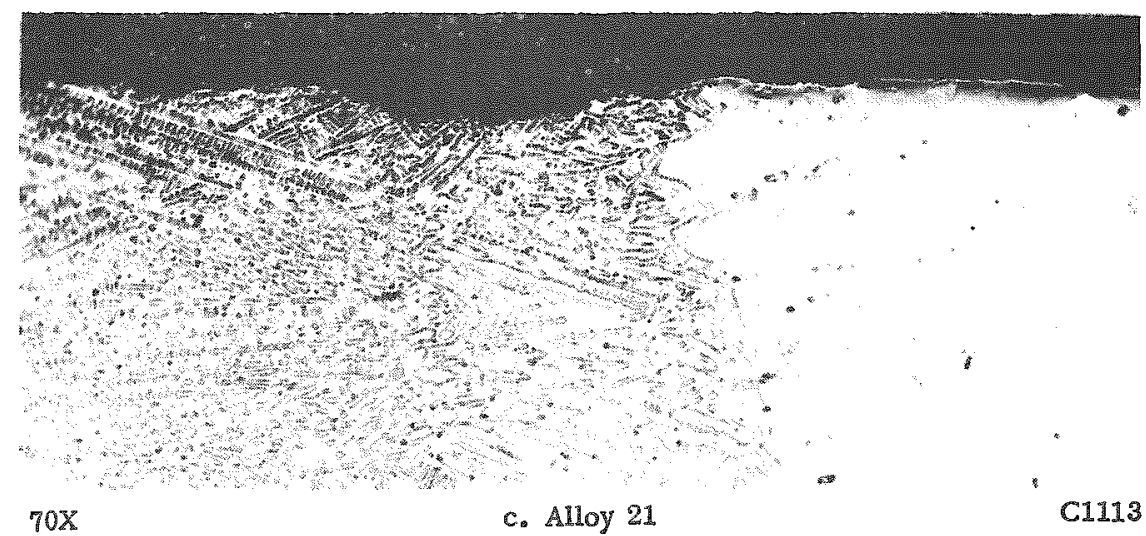

FIGURE 23. CROSS SECTIONS OF SUBMERGED, SELF-WELDED SPECIMENS SHOWING WELDMENT AND BASIS MET AL AFTER EXPOSURE TO NIFLEX SOLUTION

Only Alloy 21, of these three alloys, was selectively attacked. 


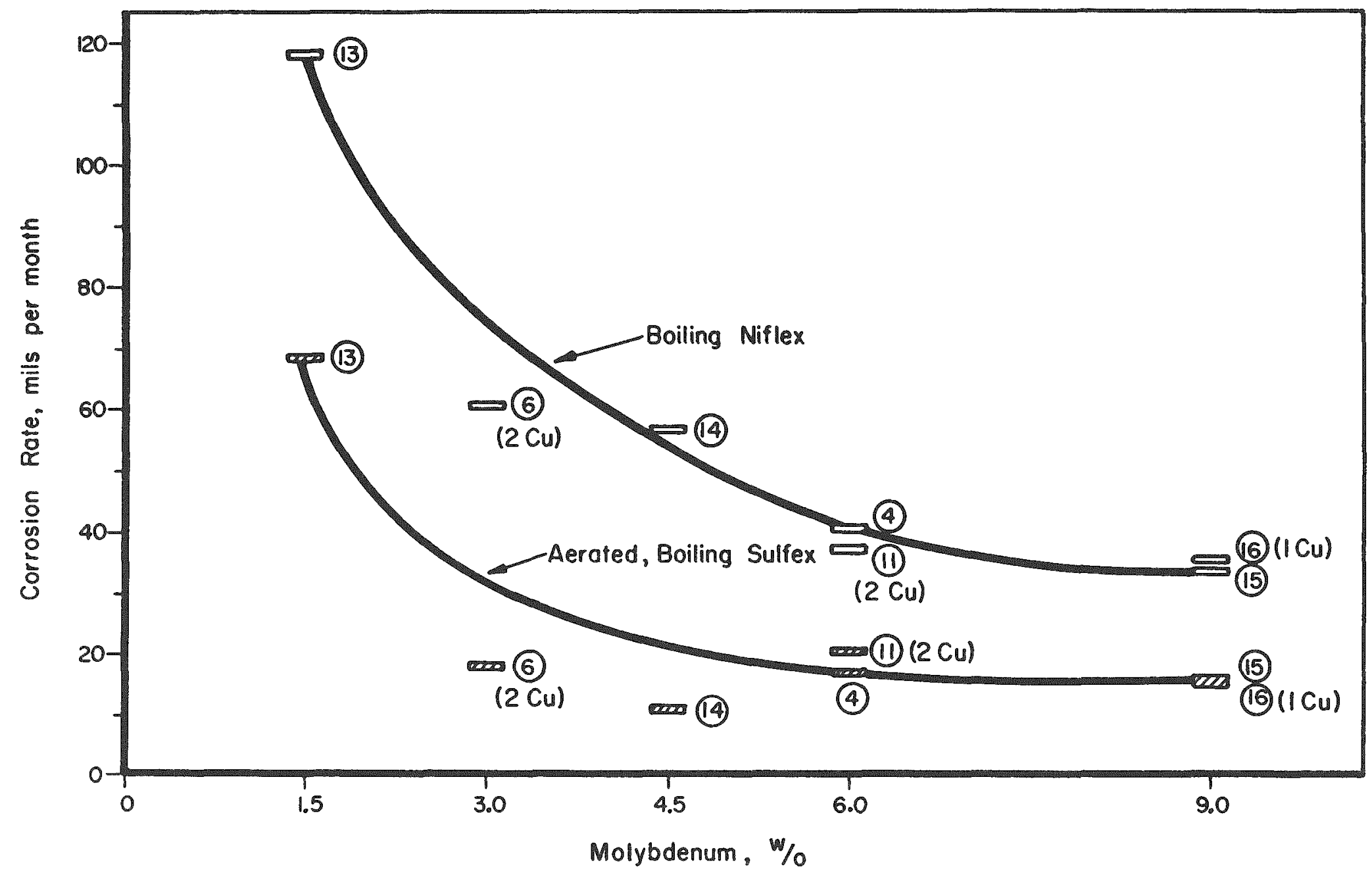

FIGURE 24. EFFECT OF COPPER AND MOLYBDENUM CONTENTS ON THE CORROSION RATES OF SELF-WELDED, SUBMERGED SPECIMENS FROM TFE $45 \mathrm{w} / 0$ NICKEL-22 w/ O CHROMIUM-1 w/o TITANIUM GROUP OF ALLOYS

Rates plotted are averaged values for duplicate specimens over five 24 -hr exposure periods. 


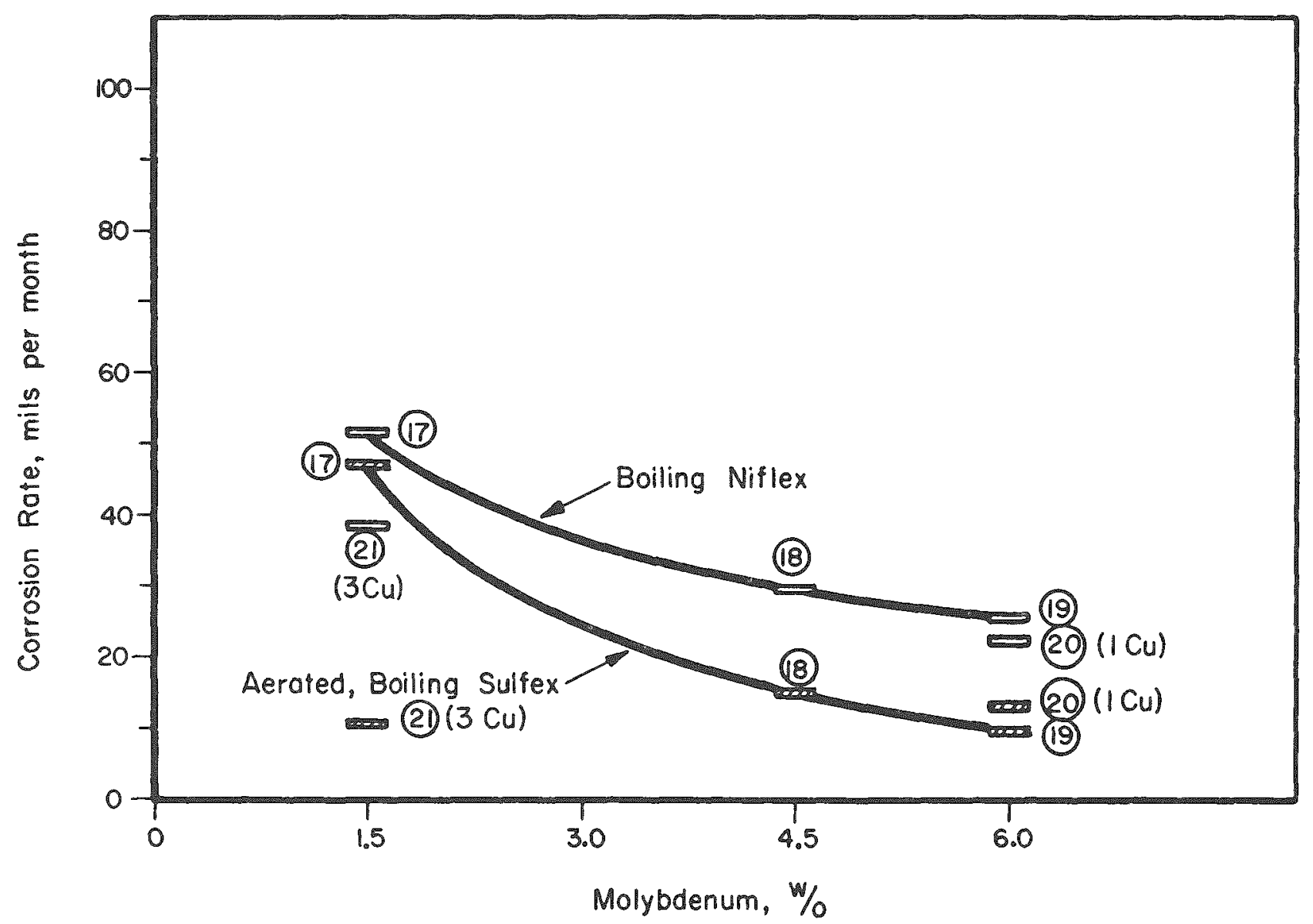

FIGURE 25. EFFECT OF COPPER AND MOLYBDENUM CONTENTS ON THE CORROSION RATES OF SELF-WELDED, SUBMERGED SPECIMENS FROM THE 50 w/O NICKEL-25 w/o CHROMIUM1 W/O TITANIUM GROUP OF ALLOYS

Rates plotted are averaged values for duplicate specimens over five $24-h^{\circ}$ exposure periods. 
corrosion resistance. It would appear that, among the compositions studied. Alloys 19 and 20 were optimum. Further improvement might be obtained if the chromium and nickel contents were increased as far as is possible without impairing workability.

TABLE 22. INFLUENCE OF COPPER AND MOLYBDENUM CONTENT ON THE CORROSION RATES OF SUBMERGED, SELF-WELDED SPECIMENS

\begin{tabular}{|c|c|c|c|c|}
\hline \multirow[b]{2}{*}{ Alloy } & \multicolumn{2}{|c|}{ Composition (a), w/o } & \multicolumn{2}{|c|}{$\begin{array}{c}\text { Corrosion } \text { Rate }^{(b)} \text {, mils } \\
\text { per month }\end{array}$} \\
\hline & Molybdenum & Copper & Sulfex & Niflex \\
\hline \multicolumn{5}{|c|}{45 w/o Nickel- 22 w/o Chromium-1 w/o Titanium Group } \\
\hline 13 & 1.5 & $=-$ & 68.3 & 118.1 \\
\hline 6 & 3 & 2 & 17.8 & 60.6 \\
\hline 14 & 4.5 & - & 11.1 & 56.5 \\
\hline 4 & 6 & -- & 17.1 & 40.6 \\
\hline 11 & 6 & 2 & 20.5 & 37.3 \\
\hline 15 & 9 & - & 16.7 & 33.4 \\
\hline 16 & 9 & 1 & 16.0 & 35.4 \\
\hline \multicolumn{5}{|c|}{50 w/o Nickel- 25 w/o Chromium-1 w/o Titanium Group } \\
\hline 17 & 1.5 & - & 47.1 & 51.5 \\
\hline 21 & 1.5 & 3 & 10.5 & 38.4 \\
\hline 18 & 4.5 & - & 15.1 & 29.5 \\
\hline 19 & 6 & - & 9.36 & 25.6 \\
\hline 20 & 6 & 1 & 13.1 & 22.3 \\
\hline
\end{tabular}

(a) Base composition includes $0.6 \mathrm{w} / \mathrm{o}$ manganese, $0.4 \mathrm{w} / \mathrm{o}$ silicon, $0.02 \mathrm{w} / \mathrm{o}$ carbon, balance uron.

(b) Averaged corrosion rates for duplicate specimens over five 24 -hr exposure periods.

Recommended compositional limits for the most promising alloys are shown in Table 23. Based on previous melting experience no difficulties would be expected in holding these limits by commercial vacuum-melting practice.

TABLE 23. SUGGESTED COMPOSITIONAL LIMITS FOR THE MOST PROMISING OF THE EXPERIMENTAL ALLOYS

\begin{tabular}{|c|c|c|c|c|c|c|c|c|}
\hline \multirow[b]{2}{*}{ Alloy } & \multicolumn{8}{|c|}{ Composition (Balance Nickel)(a), w/o } \\
\hline & $\mathrm{Cr}$ & Mo & $\mathrm{Cu}$ & $\mathrm{C}$ & $\mathrm{Si}$ & $\mathrm{Mn}$ & $\mathrm{Ti}$ & Fe \\
\hline 19 & $24-26$ & $5.5-6.5$ & $-\infty$ & $0.02 \mathrm{max}$ & $0.3-0.5$ & $0.3-0.5$ & $0.5-1.0$ & $17 \max$ \\
\hline 20 & $24-26$ & $5.5-6.5$ & $0.9-1.1$ & $0.02 \max$ & $0.3-0.5$ & $0.3-0.5$ & $0.5-1.0$ & $16 \max$ \\
\hline 21 & $24-26$ & $1.0-2.0$ & $2.8-3.2$ & $0.02 \mathrm{max}$ & $0.3-0.5$ & $0.3-0.5$ & $0.5-1.0$ & $18.5 \max$ \\
\hline 4 & $21-23$ & $5.5-6.5$ & $-\infty$ & $0.02 \mathrm{max}$ & $0.3-0.5$ & $0.3-0.5$ & $0.5-1.0$ & $26 \max$ \\
\hline 11 & $21-23$ & $5.5-6.5$ & $1.8-2.4$ & $0.02 \max$ & $0.3-0.5$ & $0.3-0.5$ & $0.5-1.0$ & $23 \max$ \\
\hline
\end{tabular}

(a) Maximum phosphorus and sulfur: $0.01 \mathrm{~W} / \mathrm{O}$. 
Quantities of Alloys 4, 11, 20, and 21 in the 35-1b range have been furnished to HAPO for further evaluations. All four of these alloys forged and rolled very well, exhibiting no significant differences when worked in these larger heats. If, as expected, the results of these evaluations bear out the conclusions drawn from the present research, especially when the use of these alloys is extended to other decladding processes, a further development program may be desirable. In this program, higher contents of chromium and nickel with balanced amounts of copper, molybdenum, and titanium could be surveyed to establish the optimum alloy from the standpoint of corrosion $x e-$ sistance and forgeability.

\section{ACKNOW LEDGMENT}

Several Battelle staff members were closely associated with these investigations. The authors are particularly indebted to Drs. H. A. Pray and P. D. Miller and Messrs. F. W. Fink, R. E. Monroe, and C. H. Lund for their helpful consultations and to Messrs. J. D. Jackson, W. J. Lepkowski, W. C. Baytos, R. D. Tenaglia, H. R. Ball, W. N. Stiegelmeyer, J. C. Vargo, and A. W. Pea for their technical assistance.

Excellent cooperation and technical liaison was maintained with the Development and Corrosion Chemistry Group at HAPO through the offices of Dr.R. F. Burns and Mr.R. F. Maness.

\section{REFERENCES}

(1) Maness, R. F., "Power Reactor Fuels Reprocessing Progress Report on Corrosion Studies", HW-61662 (August 26, 1959).

(2) Cooper, V.R., "Quarterly Report, Technology of Non-Production Reactor Fuels Reprocessing, Budget Activity 2790", HW-63406 (January 20, 1960).

(3) Peterson, C. L., Miller, P. D., Jackson, J. D., and Fink, F. W., "Construction Materials for Various Head-End Processes for the Aqueous Reprocessing of Spent Fuel Elements", BMI-1375 (April 28, 1959).

CLP:DCD:MEL:AMH: WKB / mmk 